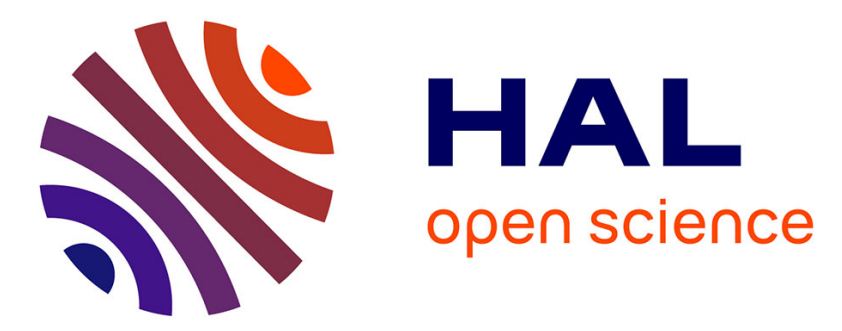

\title{
Rare elements enrichment in crustal peraluminous magmas: insights from partial melting experiments
}

Julie Anne-Sophie Michaud, Michel Pichavant, Arnaud Villaros

\section{To cite this version:}

Julie Anne-Sophie Michaud, Michel Pichavant, Arnaud Villaros. Rare elements enrichment in crustal peraluminous magmas: insights from partial melting experiments. Contributions to Mineralogy and Petrology, 2021, 176 (11), 33 p. 10.1007/s00410-021-01855-9 . insu-03431952

\section{HAL Id: insu-03431952 \\ https://hal-insu.archives-ouvertes.fr/insu-03431952}

Submitted on 17 Nov 2021

HAL is a multi-disciplinary open access archive for the deposit and dissemination of scientific research documents, whether they are published or not. The documents may come from teaching and research institutions in France or abroad, or from public or private research centers.
L'archive ouverte pluridisciplinaire HAL, est destinée au dépôt et à la diffusion de documents scientifiques de niveau recherche, publiés ou non, émanant des établissements d'enseignement et de recherche français ou étrangers, des laboratoires publics ou privés. 


\title{
Rare elements enrichment in crustal peraluminous magmas: insights from partial melting experiments
}

\author{
Julie Anne-Sophie Michaud ${ }^{1}$ (1) $\cdot$ Michel Pichavant $^{1} \cdot$ Arnaud Villaros $^{1}$
}

Received: 13 April 2021 / Accepted: 13 October 2021

(c) The Author(s), under exclusive licence to Springer-Verlag GmbH Germany, part of Springer Nature 2021

\begin{abstract}
Experiments were conducted to explore the behavior of $\mathrm{Li}, \mathrm{Rb}, \mathrm{Nb}, \mathrm{Sn}, \mathrm{Cs}, \mathrm{Ta}, \mathrm{W}$ during crustal melting and test the anatectic origin of rare metal-bearing peraluminous granites such as rare metal granites (RMGs). The experiments were performed under fluid-absent conditions at 800 and $850{ }^{\circ} \mathrm{C}, 400 \mathrm{MPa}$ and moderately reducing $\mathrm{fO}_{2}(\Delta \mathrm{FMQ}=-0.5$ to -0.8$)$. Starting materials were cores of several millimetres drilled from two natural rocks, a biotite-rich paragneiss $(\mathrm{Pg})$ and a muscoviterich orthogneiss $(\mathrm{Og})$ enriched in $\mathrm{Li}, \mathrm{Be}, \mathrm{Sn}, \mathrm{Cs}$, W. Both protoliths produced small melt fractions from 8 to $20 \%$ vol. Melt distributions were either homogeneously distributed at grain boundaries in the Pg or preferentially associated with muscovite reaction zones in the $\mathrm{Og}$. In the $\mathrm{Pg}$ at $800{ }^{\circ} \mathrm{C}$, melting is mainly fluid present, driven by interstitial water at grain boundaries. At $850^{\circ} \mathrm{C}$, biotite dehydration-melting produces peritectic orthopyroxene, hercynitic spinel, ilmenite and alkali feldspar in addition to melt. In the $\mathrm{Og}$, muscovite dehydration-melting generates melt plus peritectic biotite, hercynitic spinel, ilmenite, Al silicates and alkali feldspar. Experimental glasses are nearly homogeneous, silica rich, peraluminous and leucogranitic and their major element compositions differ only little between the two protoliths. In contrast, the trace element concentrations vary as a consequence of chemical and textural heterogeneities in our starting materials. Compared with source rocks, the $\mathrm{Og}$ glasses are enriched in $\mathrm{Rb}, \mathrm{Nb}, \mathrm{Ta}, \mathrm{W}$ and depleted in $\mathrm{Li}, \mathrm{Cs}$ and the $\mathrm{Pg}$ are enriched in $\mathrm{Li}, \mathrm{Rb}, \mathrm{Cs}, \mathrm{W}$ and depleted in $\mathrm{Nb}$, Ta. Mass-balance calculations indicate that during muscovite dehydration-melting, $\mathrm{Li}, \mathrm{Cs}$ and $\mathrm{Rb}$ partition into the melt; whereas $\mathrm{Nb}$, Ta and $\mathrm{W}$ are preferentially incorporated in peritectic phases. Li and $\mathrm{Cs}$ also partition toward the melt during biotite dehydration-melting. The partitioning behavior of trace elements during crustal melting is a function of the melting reaction and partition coefficients between melt, residual and peritectic phases. Experimental glasses are similar to peraluminous muscovite granites but fail to reproduce RMG compositions. Alternatives to mica dehydration-melting such as fluid-present and residual source melting emphasize the difficulties with an origin of RMGs by purely anatectic processes. Crystallization differentiation might have to be combined with mica dehydration-melting to explain the distinctive geochemical features of RMGs.
\end{abstract}

Keywords Melting experiments $\cdot$ Granitic magma $\cdot$ Anatectic origin $\cdot$ Rare element distribution

\section{Introduction}

The origin of rare elements concentrations (i.e., $\mathrm{Li}, \mathrm{Rb}$, $\mathrm{Cs}, \mathrm{Nb}, \mathrm{Ta}, \mathrm{W}, \mathrm{Sn}$ ) in peraluminous crustal melt remains a controversial issue and there is still a need to investigate

Communicated by Othmar Müntener.

Julie Anne-Sophie Michaud

julie.michaud@outlook.fr;

j.michaud@mineralogie.uni-hannover.de

1 Université d'Orléans, CNRS, BRGM, ISTO, UMR 7327, 45071 Orléans, France potential enrichment mechanisms. Best examples are highly evolved rare metal granites (RMGs) and their volcanic equivalents (e.g., French Massif Central: Raimbault et al. 1995; Raimbault and Burnol 1998; China: Belkasmi et al. 2000; Zhu et al. 2001; Finland: Haapala and Likkari 2005; Algeria: Kesraoui et al. 2000; Namibia: Schmitt et al. 2000; Nigeria: Kinnaird et al. 1985; Egypt: Renno 1997; Canada: Kontak 1990; Pillet et al. 1992; Russia: Raimbault et al. 1995; Mongolia: Kovalenko et al. 1995). They include peraluminous highly phosphorous RMGs (i.e., PHP, Linnen and Cuney 2005), characterized by high concentrations in fluxing elements $(\mathrm{F}, \mathrm{B}, \mathrm{Li}, \mathrm{P})$ and strong enrichments in rare lithophile elements and metals ( $\mathrm{Sn}, \mathrm{Nb}, \mathrm{Ta}, \mathrm{Be}, \mathrm{Cs}, \mathrm{Rb}, \mathrm{W}$, 
U). Studies of volcanic analogs (Kovalenko and Kovalenko 1976; Pichavant et al. 1988a, b; Raimbault and Burnol 1998) have demonstrated the key role of magmatic processes in rare elements concentration. Yet, two models are presently competing on the origin of RMGs. Numerous studies (e.g., Cameron 1949; Jahn and Burnham 1969; Raimbault 1987; Černý 1991, Černý 1992; Raimbault et al. 1995; Breaks et al. 2005; Černý et al. 2005; London 2008; Roda-Robles et al. 2018; Hulsbosch 2019) have proposed that rare element PHP-type magmas result from extreme fractionation of less evolved peraluminous parental magmas (e.g., Shearer et al. 1987; Černý and Ercit 2005; London 2005; Cuney and Barbey 2014; Villaros and Pichavant 2019). However, spatial and chronological relationships between less evolved granites and RMGs are not always consistent with derivation of the latter from the former (e.g., Deveaud et al. 2013; Goodenough et al. 2014; Melleton et al. 2015). This has led to the alternative model of origin of RMGs through partial melting of the crust (i.e., the anatectic model; e.g., Stewart 1978; Christiansen et al. 1986; Manning and Hill 1990; Cuney et al. 1992; Shearer et al. 1992; Nabelek et al. 1992a, b; Falster et al. 1997; Roda et al. 1999; Shaw et al. 2016; Simons et al. 2016; Muller et al. 2017). As an illustration, Nabelek et al. (1992a, b) suggested that the diversity of Black Hill pegmatite geochemistry and mineralogy results from variable melting conditions rather than from different degrees of crystallization differentiation. Although enriched melts such as RMGs represent important rare elements reservoirs, not all rare element deposits are related to such highly evolved igneous bodies. There are numerous examples of a strong spatial relationship between, on the one hand, peraluminous muscovite/two-mica granites and W-deposits and, on the other hand, peraluminous biotite granites and Sn-deposits (e.g., Simons et al. 2016; Harlaux et al. 2018; Hulsbosch 2019; Yuan et al. 2019; Neiva 2002). This suggests that peraluminous crustal melts can have specific rare element signatures and levels of enrichments.

Partial melting is a first-order chemical differentiation process which redistributes elements within the crust. Pressure and temperature conditions, the nature and mineralogy of the source rock and melting mechanisms such as presence or absence of a fluid phase are the main factors controlling crustal anatexis. During the melting reaction, incompatible elements partition into the melt while compatible elements are preferentially trapped in minerals. The solid residuum left upon partial melting (restite, Chappell et al. 1987) comprises different types of phases (Villaros et al. 2018a): (1) refractory phases that are not significantly reacted during the melting process; (2) reactant phases initially present in the source in excess than required by the stoichiometry of the melting reaction and which remain residual; (3) peritectic phases that are produced along with melt if the melting reaction is of peritectic or incongruent type and (4) accessory phases with trace elements as essential structural constituents (ESC, e.g., zircon for $\mathrm{Zr}$ ) whose behavior is controlled by their solubility in the melt. Thus, rare elements are redistributed and eventually concentrated in the melt according to the melting behavior of their respective mineral carriers. In most crustal source rocks, micas combine high modal abundances and the ability to concentrate a large number of trace elements (e.g., Bea et al. 1994; Nabelek 1999; Yang and Rivers 2000) although for some elements accessory phases are critical (e.g., Bea and Montero 1999). Therefore, an examination of the melting behavior of micas is necessary to understand how rare elements will distribute during crustal anatexis.

The melting relations of muscovite and biotite have been extensively studied during the 70s and 80s (Brown and Fyfe 1970; Burnham 1979). Both minerals are important sources of water for fluid-absent dehydration-melting which represents an important mechanism for granite magma generation (Thompson 1982; Clemens and Vielzeuf 1987; Le Breton and Thompson 1988; Vielzeuf and Holloway 1988; Vielzeuf and Clemens 1992). However, those studies have focused on phase relations and major element compositions of melts and coexisting minerals (e.g., Le Breton and Thompson 1988; Vielzeuf and Holloway 1988; Montel and Vielzeuf 1994, 1997; Patiño Douce and Harris 1998). Few studies have explored the behavior of trace elements during crustal melting. Rushmer (2001) presented preliminary results on the $\mathrm{Sr}, \mathrm{Ba}$ and $\mathrm{Ce}$ signature of melts formed by dehydrationmelting of muscovite. Icenhower and London (1995) studied the partitioning of $\mathrm{Li}, \mathrm{Ba}, \mathrm{Sr}, \mathrm{Rb}, \mathrm{Cs}$ between muscovite, biotite and peraluminous silicic melt at $200 \mathrm{MPa}$ under $\mathrm{H}_{2} \mathrm{O}$-saturated conditions but high proportions of melt were obtained (i.e., $\sim 50 \mathrm{vol} \%$ at $700{ }^{\circ} \mathrm{C}$ ). Recently, the generation of Li-enriched melts was investigated from low degree partial melting experiments of a staurolite-bearing gneiss at $700 \mathrm{MPa}, 650-750{ }^{\circ} \mathrm{C}$ but no trace element data were reported for the glasses (Konzett et al. 2018). The dependence between the trace element signature of the melt and the stoichiometry of the melting reaction has been theoretically explored for pelitic rocks (Harris and Inger 1992; Harris et al. 1995) and only $\mathrm{Ba}, \mathrm{Sr}$ and $\mathrm{Rb}$ were modeled (Harris and Inger 1992). The behavior of $\mathrm{Nb}$ and Ta was tackled by Stepanov and Hermann (2013) who showed that $\mathrm{Nb}$ preferentially partitions in the residue than in the melt. Ta-enriched melts can be generated by crustal melting in the presence of residual biotite (Stepanov et al. 2014). For Sn, the variable partitioning behavior between leucosome and restite in migmatites was attributed to the stability of $\mathrm{Sn}$ sequestering minerals during melt generation (Wolf 2018; Wolf et al. 2018).

This paper presents results of partial melting experiments on two natural mica-bearing lithologies as a test of mechanisms of rare element enrichment in granitic melts. We focus 
on melting textures and reactions, on the nature of peritectic mineral phases and on experimental melt major and trace element compositions, notably for rare lithophile elements such as $\mathrm{Sn}, \mathrm{W}, \mathrm{Li}, \mathrm{Nb}$, Ta. The data demonstrate production of melts enriched in rare metals under specific conditions. They provide insight on the role of micas in the origin of rare elements magmas and stress the critical importance of the melting reaction and peritectic phases/melt element partitioning.

\section{Experimental approach, strategy and variables}

This study is aimed at testing the generation of rare element-enriched granitic melts by low degree partial melting of natural crustal source rocks. Degrees of melting (i) are in the $10-15 \mathrm{vol} \%$ range for peraluminous silicic magmas including PHP RMGs (Clemens and Vielzeuf 1987; Le Fort et al. 1987; Pichavant et al. 1988a, b). In contrast, in our early exploratory experiments performed under fluid-present conditions, high melt fractions ( $i \geq 0.5$, Villaros et al. $2018 b$ ) were generated. Therefore, fluid-absent conditions were subsequently imposed and experimental i were controlled from two parameters, (1) temperature (either 800 or $850{ }^{\circ} \mathrm{C}$ ) and (2) type of source rock. Pressure was kept constant (400 MPa). Low melt fractions were also targeted because, for incompatible elements (Kd mineral/melt $<<1)$, melt concentrations increase markedly when $\mathrm{F}$ drops below 0.1-0.2 (e.g., Hanson 1978), an alternative to extreme fractionation with the crystallization-differentiation model. It was expected that the detection of trace elements would be facilitated in glasses from low $\mathrm{F}$ charges given that, in this study, natural undoped starting materials have been used. However, for rare element concentrations to be determined, glass pools must be of sufficient size and this illustrates the necessary trade-off between melt fraction and glass analysis in this study.

Sources of peraluminous magmas include an important fraction of metasediments (Le Fort et al. 1987; Pichavant et al. 1988a, b; Ballouard et al. 2015) but there is also isotopic evidence for a metaigneous component (e.g., Turpin et al. 1990). Therefore, one paragneiss ( $\mathrm{Pg})$ and one orthogneiss $(\mathrm{Og})$ were selected as representative of the main protoliths involved in peraluminous silicic magma generation. The first advantage is that the behavior of each mica can be followed during partial melting (e.g., Rushmer 2001) since mica modal compositions are contrasted between the two samples (the Pg is biotite rich and contains minor muscovite, whereas the $\mathrm{Og}$ is muscovite rich with only minor biotite, see below). The second advantage is that the two protoliths have contrasting whole-rock major and trace element compositions. In particular, the Og is clearly enriched in lithophile trace elements $(\mathrm{Li}, \mathrm{Be}, \mathrm{Cs}, \mathrm{Sn}, \mathrm{W})$ compared to the Pg (Table 1 and see below) and so is representative of a pre-enriched geochemically "fertile" source rock.

Instead of powders, microcores were drilled to preserve original textures, such as presence of metamorphic layering and segregation of micas. Similar microcores have been used previously in several experimental partial melting studies (e.g., Rushmer 2001; Holyoke and Rushmer 2002; Misra et al. 2009; Tumarkina et al. 2011). This approach has the major advantage to closely simulate natural reaction mechanisms and generate textures directly relevant to crustal melting processes. The same approach is followed in this study where we focus on mechanisms of melting reactions and on the associated geochemical implications.

\section{Methods and analytical techniques}

\section{Experimental methods}

Cores ( 7-10 mm length, $2.5 \mathrm{~mm}$ diameter; Fig. 1) were drilled in each of the two starting rocks perpendicularly to the foliation and then kept in an oven before use. These were loaded without any additional volatile in Au capsules (15-25 mm length, $2.5 \mathrm{~mm}$ diameter slightly enlarged to accommodate the core samples, $0.2 \mathrm{~mm}$ wall thickness), subsequently welded shut. The $\mathrm{Og}$ and the Pg capsules were reacted together at $400 \mathrm{MPa}$ for a duration of two weeks at 800 and $850{ }^{\circ} \mathrm{C}$. The two experiments were performed in an internally heated pressure vessel operating vertically and pressurized with $\mathrm{Ar}-\mathrm{H}_{2}$ gas mixtures (Scaillet et al. 1995). During the experiments, total pressure was permanently recorded and is known to better than $\pm 2 \mathrm{MPa}$. Temperature was continuously measured by three thermocouples with an uncertainty of $\pm 5{ }^{\circ} \mathrm{C}$. At the end of each experiment, the power to the furnace was switched off and temperature dropped by about $300{ }^{\circ} \mathrm{C}$ during the first $5 \mathrm{~min}$. Simultaneously, Ar was pumped inside the vessel to keep pressure approximatively constant during quench. Capsules were checked for leaks by weighting and then opened. Experimental charges were cut in their middle parallel to their long axis, embedded in epoxy and then polished.

To generate a moderately reducing environment in the experiments, the proportion of $\mathrm{H}_{2}$ in the pressurizing gas mixture was precisely adjusted. $\mathrm{H}_{2}$ was introduced first to a constant $\mathrm{PH}_{2}$ of $0.60-0.61 \mathrm{MPa}$ and then Ar was pumped to a total pressure of $\sim 230-250 \mathrm{MPa}$ before heating up. Experimental $\mathrm{fH}_{2}$ were measured from CoPd solid sensor capsules (Taylor et al. 1992) placed in the vessel together with experimental capsules. After experiments were completed, atomic fractions of $\mathrm{Co}(\mathrm{XCo})$ in CoPd alloys were measured $\left(\mathrm{XCo}=0.45-0.46\right.$ at $800{ }^{\circ} \mathrm{C}, 0.39-0.43$ at $850{ }^{\circ} \mathrm{C}$ ) and the sensor $\mathrm{fO}_{2}$ and experimental $\mathrm{fH}_{2}\left(5.1-5.3 \mathrm{MPa}\right.$ at $800{ }^{\circ} \mathrm{C}$, 
Table 1 Whole rock compositions of the starting materials

\begin{tabular}{|c|c|c|c|}
\hline $\begin{array}{l}\text { Major elements } \\
(\mathrm{wt} \%)\end{array}$ & $\mathrm{Pg}$ & $\mathrm{Og}$ & Detection limits \\
\hline $\mathrm{SiO}_{2}$ & 69.29 & 72.03 & 0.05 \\
\hline $\mathrm{TiO}_{2}$ & 0.81 & 0.3 & 0.02 \\
\hline $\mathrm{Al}_{2} \mathrm{O}_{3}$ & 13.72 & 13.56 & 0.04 \\
\hline $\mathrm{FeO}$ & 4.6 & 1.04 & 0.015 \\
\hline $\mathrm{MnO}$ & 0.06 & 0.02 & 0.015 \\
\hline $\mathrm{MgO}$ & 1.76 & 0.44 & 0.03 \\
\hline $\mathrm{CaO}$ & 1.25 & 1.48 & 0.03 \\
\hline $\mathrm{Na}_{2} \mathrm{O}$ & 3.4 & 1.66 & 0.02 \\
\hline $\mathrm{K}_{2} \mathrm{O}$ & 2.68 & 5.94 & 0.03 \\
\hline $\mathrm{P}_{2} \mathrm{O}_{5}$ & 0.2 & 1.25 & 0.1 \\
\hline $\mathrm{F}$ & 0.05 & 0.35 & 0.002 \\
\hline LOI & 0.89 & 2.05 & \\
\hline Total & 99.22 & 99.89 & \\
\hline $\mathrm{A} / \mathrm{CNK}$ & 1.27 & 1.14 & \\
\hline $\mathrm{A}^{*}$ & 57.6 & 33.1 & \\
\hline $\mathrm{B}^{*}$ & 117.8 & 29.0 & \\
\hline \multicolumn{4}{|c|}{ Trace elements (ppm) } \\
\hline $\mathrm{Li}$ & 48 & 95 & 0.5 \\
\hline $\mathrm{Be}$ & 2.21 & 6.46 & 0.05 \\
\hline As & 11.98 & 16.56 & 0.5 \\
\hline $\mathrm{Ba}$ & 844.1 & 745.2 & 5.5 \\
\hline $\mathrm{Bi}$ & 0.18 & 0.2 & 0.045 \\
\hline $\mathrm{Cd}$ & 0.35 & 0.24 & 0.02 \\
\hline $\mathrm{Ce}$ & 102.1 & 66.62 & 0.03 \\
\hline $\mathrm{Co}$ & 9.27 & 1.5 & 0.08 \\
\hline $\mathrm{Cr}$ & 109 & 96 & 0.5 \\
\hline $\mathrm{Cs}$ & 6.64 & 34.5 & 0.02 \\
\hline $\mathrm{Cu}$ & 10.73 & bdl & 2 \\
\hline Dy & 5.03 & 5.74 & 0.004 \\
\hline $\mathrm{Er}$ & 2.68 & 2.95 & 0.002 \\
\hline $\mathrm{Eu}$ & 1.44 & 1.34 & 0.002 \\
\hline $\mathrm{Ga}$ & 19.15 & 22.4 & 0.02 \\
\hline $\mathrm{Gd}$ & 5.99 & 6.07 & 0.005 \\
\hline $\mathrm{Ge}$ & 1.97 & 2.11 & 0.04 \\
\hline Hf & 11.77 & 5 & 0.03 \\
\hline Но & 0.95 & 1.11 & 0.001 \\
\hline In & 0.08 & bdl & 0.03 \\
\hline $\mathrm{La}$ & 55.59 & 37.93 & 0.02 \\
\hline $\mathrm{Lu}$ & 0.46 & 0.39 & 0.001 \\
\hline Mo & bdl & 3.3 & 0.5 \\
\hline $\mathrm{Nb}$ & 16.7 & 11.12 & 0.015 \\
\hline $\mathrm{Nd}$ & 43.35 & 35.52 & 0.016 \\
\hline $\mathrm{Ni}$ & 23.42 & 47.66 & 2 \\
\hline $\mathrm{Pb}$ & 20.26 & 26.87 & 0.45 \\
\hline $\operatorname{Pr}$ & 12 & 9.41 & 0.004 \\
\hline $\mathrm{Rb}$ & 110.2 & 245.7 & 0.15 \\
\hline $\mathrm{Sc}$ & 12.04 & 4.16 & 0.6 \\
\hline $\mathrm{Sb}$ & 0.27 & 2.02 & 0.06 \\
\hline $\mathrm{Sm}$ & 7.75 & 7.66 & 0.005 \\
\hline
\end{tabular}

Table 1 (continued)

\begin{tabular}{llll}
\hline $\begin{array}{l}\text { Major elements } \\
(\mathrm{wt} \%)\end{array}$ & $\mathrm{Pg}$ & $\mathrm{Og}$ & Detection limits \\
\hline $\mathrm{Sn}$ & 2.81 & 217.9 & 0.3 \\
$\mathrm{Sr}$ & 175.8 & 98 & 0.7 \\
$\mathrm{Ta}$ & 1.78 & 0.93 & 0.004 \\
$\mathrm{~Tb}$ & 0.9 & 0.98 & 0.001 \\
$\mathrm{Th}$ & 17.33 & 14.5 & 0.015 \\
$\mathrm{Tm}$ & 0.42 & 0.43 & 0.001 \\
$\mathrm{U}$ & 3.92 & 2.57 & 0.01 \\
$\mathrm{~V}$ & 90.88 & 17.41 & 0.85 \\
$\mathrm{~W}$ & 2.66 & 16.96 & 0.8 \\
$\mathrm{Y}$ & 27.74 & 31.44 & 0.02 \\
$\mathrm{Yb}$ & 2.87 & 2.73 & 0.002 \\
$\mathrm{Zn}$ & 82.59 & 25.08 & 7 \\
$\mathrm{Zr}$ & 537.1 & 185.6 & 1.5 \\
$\mathrm{Nb} / \mathrm{Ta}$ & 9.4 & 12.0 & \\
\hline
\end{tabular}

$b d l$ below detection limit

$A / \mathrm{CNK}=\mathrm{Al}_{2} \mathrm{O}_{3} /\left(\mathrm{Na}_{2} \mathrm{O}+\mathrm{K}_{2} \mathrm{O}+\mathrm{CaO}\right)$ molar

$A^{*}=1000 .(\mathrm{Al}-(\mathrm{Na}+\mathrm{K}+2 \mathrm{Ca}))$ atomic (Debon and Le Fort 1983)

$B^{*}=1000 .($ Fetot $+\mathrm{Mg}+\mathrm{Ti})$ atomic (Debon and Le Fort 1983)

4.7-5.9 MPa at $850^{\circ} \mathrm{C}$ ) were determined (e.g., Scaillet et al. 1995). The $\mathrm{fO}_{2}$ within experimental capsules was calculated from the determined $\mathrm{fH}_{2}$, the formation constant of water ( $K_{\mathrm{w}}$, Robie et al. 1979) and the $\mathrm{fH}_{2} \mathrm{O}$, the latter obtained assuming concentrations of $4 \mathrm{wt} \% \mathrm{H}_{2} \mathrm{O}$ in glass using the by-difference method (Villaros et al. 2018b). In this study, $\mathrm{fO}_{2}$ was similar in the four experimental capsules, yielding deviations from the fayalite-magnetite-quartz oxygen buffer ( $\triangle \mathrm{FMQ}$ ) of -0.7 to -0.8 at $800{ }^{\circ} \mathrm{C}$ and of -0.5 to -0.7 at $850^{\circ} \mathrm{C}$.

\section{Analytical methods}

The two starting rocks were analyzed for major and trace elements at the Centre de Recherches Pétrographiques et Géochimiques (CRPG-SARM, Vandoeuvre les Nancy) by ICP-OES and ICP-MS (see details of the method in Carignan et al. 2001).

Starting and experimentally reacted samples were imaged with a Merlin compact ZEISS scanning electron microscope (SEM, ISTO, Orléans) working under an acceleration voltage of $15 \mathrm{kV}$ and equipped with a Bruker EDS detector. Backscattered electron (BSE) images (panoramas of entire experimental charges and high magnification views of detailed microtextures) and potassium X-ray distribution maps were acquired. The $2 \mathrm{D}$ images were processed to calculate experimental melt volumetric proportions. Highresolution BSE panoramas (glass and minerals distinguished from each other by gray level and texture) were superposed 
Fig. 1 Macroscopic views of the two starting materials. a $\mathrm{Og}$; b Pg. Note the differences in deformation intensities, the $\mathrm{Pg}$ being more finely banded than the $\mathrm{Og}$, and the heterogeneous mica distribution in the $\mathrm{Og}$. The white rectangles give sizes of experimental microcores
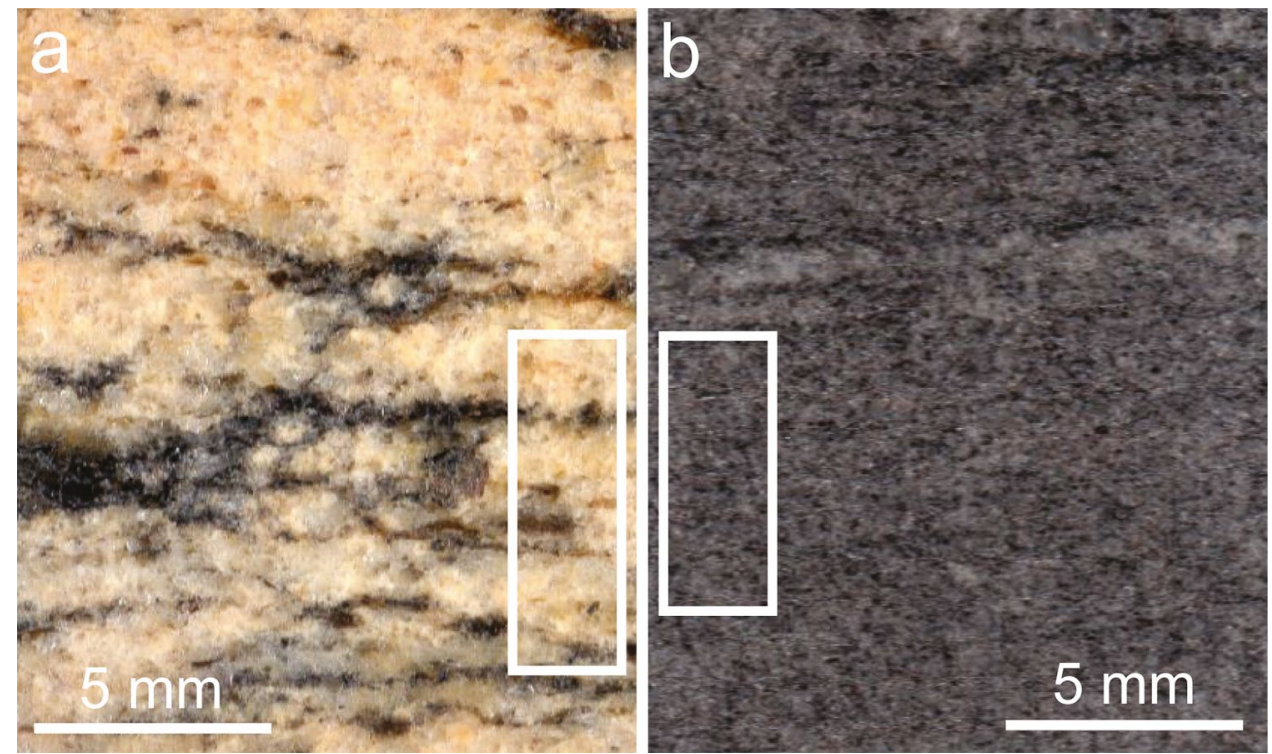

with potassium distribution maps, to image the glassy areas. $\mathrm{K}_{2} \mathrm{O}$ is a good tracer for melt pools as concentrations in melts are similar in all experimental charges (i.e., between 5 and $6 \mathrm{wt} \%$ ), and differ from other minerals such as micas. Melt zones were manually outlined and black and white images produced for the whole sample to count the number of pixels associated to $100 \%$ melt areas and the total number of pixels (Fig. A1). Muscovite and biotite reaction zones with melt intimately intermixed with fine-grained peritectic phases (see below) were also delineated and percentages of melt in these zones estimated (Table A1 and Fig. A2). As an example, in the $\mathrm{Og}$ sample at $800{ }^{\circ} \mathrm{C}$, two representative types of melt-peritectic phase mixture zones were recognized (i.e., zones a, b; Table A1 and Fig. A2). Both zones were manually outlined using small-scale BSE images. Then, black and white images were created, pixels counted, and melt proportions were calculated from the respective numbers of pixels for melt and peritectic phases, yielding 63 and $25 \%$ melt for zones a and b, respectively (Table A1 and Fig. A2). To extend the calculations at the scale of the whole sample, it was assumed that all mica reaction zones are either of type a ( $63 \%$ melt) or b ( $25 \%$ melt). Finally, the degree of melting was calculated as the number of pixels for $100 \%$ melt zones plus the number of pixels for melt in all mica reaction zones divided by the number of pixels for the whole sample. Pixel counting was performed using the ImageJ software (e.g., Schneider et al. 2012).

Mineral phases (starting materials and experimental samples) and glasses (experimental samples) were analyzed for major and minor elements using a CAMECA SX Five electron microprobe (ISTO, Orléans) operated under an acceleration voltage and a beam current of $15 \mathrm{kV}$ and $6 \mathrm{nA}$, respectively. Standards included albite $(\mathrm{Si} K \alpha$ and $\mathrm{Na} K \alpha)$, synthetic $\mathrm{MnTiO}_{3}(\mathrm{Mn} K \alpha$ and $\mathrm{Ti} K \alpha), \mathrm{Al}_{2} \mathrm{O}_{3}(\mathrm{Al} K \alpha), \mathrm{Fe}_{2} \mathrm{O}_{3}$
( $\mathrm{Fe} K \alpha), \operatorname{MgO}(\mathrm{Mg} K \alpha)$, andradite $(\mathrm{Ca} K \alpha)$, orthoclase $(\mathrm{K} K \alpha)$, apatite $(\mathrm{P} K \alpha)$ and topaz $(\mathrm{F} K \alpha)$. Mineral phases were analyzed with a focused beam (1-2 $\mu \mathrm{m})$. For glasses, spot sizes of either 15 or $50 \mu \mathrm{m}$ were used to minimize the migration of alkali and match the laser spot sizes (see below). Results were checked against analyses of Macusani glasses $\mathrm{CH} 0$ and JV2 (Pichavant et al. 1987) used as secondary standards. Glass-peritectic phase mixtures in muscovite reaction zones were also analyzed with the same beam sizes (15 and $50 \mu \mathrm{m})$. For glasses, relative analytical errors, determined as standard deviations on multiple analyses on Macusani glass $\mathrm{CH}$, are: $\mathrm{SiO}_{2}(0.5-1 \%), \mathrm{Al}_{2} \mathrm{O}_{3}(1-1.5 \%), \mathrm{FeO}(15-25 \%)$, $\mathrm{MgO}(20-40 \%), \mathrm{CaO}(10-17 \%), \mathrm{Na}_{2} \mathrm{O}(2-3.5 \%)$ and $\mathrm{K}_{2} \mathrm{O}$ (1-2\%). The electron microprobe data were also used in mass-balance calculations. Mineral modes in the two protoliths were calculated by mass-balancing the major element chemistries of the main mineral phases against the bulk (i.e., whole-rock) compositions (see Nabelek 1999). Stoichiometries of melting reactions were determined by massbalancing the major element compositions of reactants and products within the same experimental charge (see Cesare 2000). Calculations were performed on eight oxides $\left(\mathrm{SiO}_{2}\right.$, $\mathrm{TiO}_{2}, \mathrm{Al}_{2} \mathrm{O}_{3}, \mathrm{FeO}, \mathrm{MgO}, \mathrm{CaO}, \mathrm{Na}_{2} \mathrm{O}, \mathrm{K}_{2} \mathrm{O}$ ) simultaneously (i.e., using an input matrix with eight rows) and with a variable number of phases depending on the reaction, following the linear least square procedures detailed in Albarède (1995).

Trace element concentrations were determined by laser ablation inductively coupled plasma mass spectrometry (LA-ICP-MS) at Orléans (joint IRAMAT-ISTO facility). A RESOlution (S-155-E) ArF excimer laser (LA; $\lambda=193 \mathrm{~nm}$ ) coupled to a Thermo Finnigan Element XR (extended range, high-resolution) ICP-MS was used. Ablation was performed at $5 \mathrm{~Hz}$, at an energy of $\sim 5 \mathrm{~J} . \mathrm{cm}^{-2}$. $\mathrm{SiO}_{2}$ from electron 
microprobe analysis was used as an internal standard. Mineral phases from the two starting rocks were analyzed with $50 \mu \mathrm{m}$ spots. Experimental glasses were analyzed with spots of either 15 or $50 \mu \mathrm{m}$ size depending on the texture and width of glass zones. Glass plus peritectic phase mixtures from muscovite reaction zones were also analyzed with spots of 15 and $50 \mu \mathrm{m}$ to constrain compositions of bulk peritectic phase assemblages. NIST610 was used as an external standard (Pearce et al. 1997) and Macusani glasses CHO and JV2 (Pichavant et al. 1987) as control. Reference glasses (NIST610 and Macusani) were analyzed three times at the beginning and at the end of each run of ten analyses. For mineral phases, 39 isotopes $\left(\mathrm{Li}^{7}, \mathrm{Be}^{9}, \mathrm{~B}^{11}, \mathrm{Na}^{23}, \mathrm{Al}^{27}, \mathrm{Si}^{29}\right.$, $\mathrm{P}^{31}, \mathrm{~K}^{39}, \mathrm{Sc}^{45}, \mathrm{Ti}^{49}, \mathrm{~V}^{51}, \mathrm{Zn}^{66}, \mathrm{Zn}^{68}, \mathrm{Rb}^{85}, \mathrm{Sr}^{88}, \mathrm{Y}^{89}, \mathrm{Zr}^{90}$, $\mathrm{Nb}^{93}, \mathrm{Sn}^{118}, \mathrm{Cs}^{133}, \mathrm{Ba}^{137}, \mathrm{La}^{139}, \mathrm{Ce}^{140}, \mathrm{Pr}^{141}, \mathrm{Nd}^{144}, \mathrm{Sm}^{147}$, $\mathrm{Eu}^{153}, \mathrm{Gd}^{157}, \mathrm{~Tb}^{159}, \mathrm{Dy}^{163}, \mathrm{Ho}^{165}, \mathrm{Er}^{167}, \mathrm{Tm}^{169}, \mathrm{Yb}^{172}, \mathrm{Lu}^{175}$, $\mathrm{Hf}^{178}, \mathrm{Ta}^{181}, \mathrm{~W}^{182}, \mathrm{~Pb}^{208}$ ) were analyzed and for experimental glasses and glass-peritectic phase mixtures 21 isotopes $\left(\mathrm{Li}^{7}, \mathrm{Be}^{9}, \mathrm{~B}^{11}, \mathrm{Na}^{23}, \mathrm{Al}^{27}, \mathrm{Si}^{29}, \mathrm{P}^{31}, \mathrm{~K}^{39}, \mathrm{Cu}^{63}, \mathrm{Zn}^{64}, \mathrm{Zn}^{66}\right.$, $\mathrm{Rb}^{85}, \mathrm{Sr}^{88}, \mathrm{Nb}^{93}, \mathrm{Sn}^{118}, \mathrm{Cs}^{133}, \mathrm{Ba}^{137}, \mathrm{Ba}^{138}, \mathrm{Ta}^{181}, \mathrm{~W}^{182}$, $\mathrm{U}^{238}$ ). The raw data were processed off-line using the Glitter software where time-resolved signals were examined one by one. Element concentrations were calculated for the initial $30 \mathrm{~s}$ of all ablation signals relative to the gas blank $(\sim 20 \mathrm{~s})$, with a linear interpolation across standard analyses.

\section{Results}

\section{Source rocks: mineralogy, composition and trace element distribution}

The $\mathrm{Og}$ and Pg source rocks are Variscan gneisses belonging to the Lower Gneiss Unit (LGU) and were sampled near Chalus in the Limousin part of northwestern French Massif Central (FMC). The LGU is composed of metagreywackes, metapelites and metarhyolites intruded by Cambrian-early Ordovician granitoids transformed into orthogneisses during the Variscan orogeny (e.g., Faure et al. 2009). The LGU underwent two phases of metamorphism during the Midlle Devonian and the Late Devonian-Early Carboniferous and mostly of amphibolite grade (Faure et al. 2009). The two rocks are deformed, the foliation in the Og being less strongly marked than in the finely banded Pg (Fig. 1). Both samples are texturally homogeneous and there is no evidence for migmatisation and partial melting. Mass-balance calculations using the whole-rock (Table 1) and the major element compositions of the main mineral phases (Tables 2, A2) show that the Og is remarkably muscovite rich with $35 \%$ quartz, $29 \%$ alkali feldspar, $18 \%$ plagioclase, $3 \%$ biotite and $13 \%$ muscovite. The rock also contains $2 \%$ apatite and a few garnets. Using the same calculations, the Pg hosts $34 \%$ quartz, $5 \%$ alkali feldspar, $37 \%$ plagioclase, $20 \%$ biotite, $3 \%$ garnet, $1 \%$ kyanite and contains minor muscovite. Pressure-temperature estimations with mineral thermobarometers and PerpleX pseudo sections constructed using bulk rock and mineral compositions have yielded conditions of metamorphic equilibration of $600{ }^{\circ} \mathrm{C}-450 \mathrm{MPa}$ for
Table 2 Representative EMPA compositions of micas in the $\mathrm{Pg}$ and $\mathrm{Og}$ starting materials

\begin{tabular}{|c|c|c|c|c|c|c|c|c|c|}
\hline \multirow{2}{*}{$\begin{array}{l}\text { Major ele- } \\
\text { ments (wt\%) }\end{array}$} & \multicolumn{3}{|l|}{$\mathrm{Pg}$} & \multicolumn{6}{|l|}{$\mathrm{Og}$} \\
\hline & $\mathrm{Bt}$ & & & $\mathrm{Bt}$ & & & Ms & & \\
\hline $\mathrm{SiO}_{2}$ & 35.235 & 35.729 & 35.403 & 33.843 & 34.536 & 34.538 & 48.359 & 47.877 & 47.349 \\
\hline $\mathrm{TiO}_{2}$ & 3.537 & 3.992 & 3.757 & 2.264 & 2.473 & 2.569 & 0.622 & 0.511 & 0.782 \\
\hline $\mathrm{Al}_{2} \mathrm{O}_{3}$ & 18.507 & 18.516 & 18.922 & 17.1 & 16.69 & 16.875 & 32.46 & 32.507 & 32.477 \\
\hline FeOtot & 17.685 & 17.47 & 18.032 & 27.365 & 26.105 & 26.285 & 2.98 & 3.24 & 2.968 \\
\hline $\mathrm{MnO}$ & 0.064 & 0.128 & 0.108 & 0.345 & 0.303 & 0.307 & 0.00 & 0.106 & 0.023 \\
\hline $\mathrm{MgO}$ & 8.027 & 8.18 & 7.92 & 2.913 & 3.375 & 3.452 & 0.725 & 0.67 & 0.673 \\
\hline $\mathrm{CaO}$ & - & - & - & - & - & 0.011 & 0.025 & 0.019 & - \\
\hline $\mathrm{Na}_{2} \mathrm{O}$ & 0.088 & 0.158 & 0.187 & 0.036 & 0.026 & 0.08 & 0.435 & 0.393 & 0.362 \\
\hline $\mathrm{K}_{2} \mathrm{O}$ & 9.55 & 9.313 & 9.472 & 9.135 & 8.894 & 9.035 & 9.594 & 8.98 & 9.664 \\
\hline $\mathrm{P}_{2} \mathrm{O}_{5}$ & 0.147 & - & 0.038 & 0.038 & 0.008 & 0.145 & - & 0.023 & 0.051 \\
\hline F & 0.149 & 0.162 & 0.139 & 0.349 & 0.4 & 0.404 & 0.161 & 0.267 & 0.185 \\
\hline Total & 0.00 & 0.00 & 0.00 & 0.00 & 0.00 & 0.00 & 0.00 & 0.00 & 0.00 \\
\hline Mg\# & 0.45 & 0.45 & 0.44 & 0.16 & 0.19 & 0.19 & 0.30 & 0.27 & 0.29 \\
\hline
\end{tabular}

$\mathrm{Bt}$ biotite, $\mathrm{Ms}$ muscovite, $\mathrm{FeO}$ tot total $\mathrm{Fe}$ as $\mathrm{FeO}$

$\mathrm{Mg} \#=\mathrm{Mg} /(\mathrm{Mg}+\mathrm{Fe})$ at 
the paragneiss and of $650{ }^{\circ} \mathrm{C}-400 \mathrm{MPa}$ for the orthogneiss (Gaudel 2016).

The major element data (Table 1) show that the Pg is more mafic $\left(\mathrm{FeO}=4.60 \mathrm{wt} \%, \mathrm{MgO}=1.76 \mathrm{wt} \%, B^{*}=118\right)$ than the $\mathrm{Og}\left(\mathrm{FeO}=1.04 \mathrm{wt} \%, \mathrm{MgO}=0.44 \mathrm{wt} \%, B^{*}=29\right)$, whereas the $\mathrm{Og}$ is more potassic $\left(5.94\right.$ vs. $2.68 \mathrm{wt} \% \mathrm{~K}_{2} \mathrm{O}$ ) and remarkably $\mathrm{P}_{2} \mathrm{O}_{5}$ rich $(1.25 \mathrm{wt} \%)$. Both rocks are peraluminous, the $\mathrm{Pg}$ more than the $\mathrm{Og}(\mathrm{A} / \mathrm{CNK}=1.27$ and $1.14 ; A^{*}=58$ and 33 , respectively). In terms of trace elements, the Pg is enriched in Ta (1.78 ppm), Nb (16.70 ppm), LREE $(\mathrm{Ce}=102.1 \mathrm{ppm}, \mathrm{La}=55.59 \mathrm{ppm}), \mathrm{Zr}(537.1 \mathrm{ppm})$ and Th (17.33 ppm) compared to the Og. This latter sample is consistently enriched in rare elements and metals such as Li (95 ppm), Be (6.46 ppm), Cs (34.5 ppm), Sn (217.9 ppm) and $\mathrm{W}(17.4 \mathrm{ppm})$ when compared to the Pg.

The trace element data (Table 3) show that, in the Pg, biotites are enriched in $\mathrm{Li}(\sim 163-218 \mathrm{ppm})$ and contain relatively high amounts of $\mathrm{Rb}, \mathrm{Nb}, \mathrm{Sn}, \mathrm{Cs}, \mathrm{Ba}, \mathrm{Ta}$ and $\mathrm{W}$, although in quite variable concentrations (e.g., $~ 56-126 \mathrm{ppm}$ $\mathrm{Nb}, \sim 3-12 \mathrm{ppm} \mathrm{Ta}$ ). The other major phases have lower rare lithophile element and metal concentrations but we note that garnet and quartz contain some $\mathrm{Li}$ and plagioclase some $\mathrm{Be}$
Table 3 Representative LA-ICP-MS trace element compositions of micas from starting materials

\begin{tabular}{|c|c|c|c|c|c|c|c|c|c|}
\hline \multirow{3}{*}{$\begin{array}{l}\text { Trace } \\
\text { elements } \\
(\mathrm{ppm}) \\
\mathrm{Li}\end{array}$} & \multirow{2}{*}{\multicolumn{3}{|c|}{$\frac{\mathrm{Pg}}{\mathrm{Bt}}$}} & \multicolumn{6}{|l|}{$\mathrm{Og}$} \\
\hline & & & & \multicolumn{3}{|l|}{$\mathrm{Bt}$} & \multicolumn{3}{|l|}{ Ms } \\
\hline & 218.65 & 188.69 & 163.22 & 58.52 & 178.26 & 209.07 & 74.22 & 87.86 & 78.73 \\
\hline $\mathrm{Be}$ & 0.97 & 0.85 & 0.92 & 1.85 & 2.10 & 0.95 & 2.59 & 2.43 & 2.47 \\
\hline B & 2.99 & 3.85 & 5.32 & 3.84 & 1.04 & 1.68 & 7.40 & 6.71 & 7.06 \\
\hline $\mathrm{Sc}$ & 36.04 & 36.95 & 36.34 & 25.03 & 19.38 & 16.90 & 38.10 & 42.46 & 38.54 \\
\hline $\mathrm{Ti}$ & $21,034.0$ & $21,444.0$ & $21,074.0$ & 5772.7 & $18,861.4$ & $14,128.0$ & 3815.1 & 4032.9 & 4147.4 \\
\hline V & 393.6 & 361.1 & 349.1 & 48.72 & 66.59 & 69.41 & 50.77 & 53.26 & 57.47 \\
\hline${ }^{66} \mathrm{Zn}$ & 346.3 & 349.9 & 310.3 & 28.70 & 411.5 & 461.3 & 32.75 & 37.39 & 32.71 \\
\hline${ }^{68} \mathrm{Zn}$ & 300.4 & 317.0 & 300.2 & 40.73 & 206.4 & 179.1 & 46.14 & 50.49 & 43.52 \\
\hline $\mathrm{Rb}$ & 488.7 & 495.9 & 466.1 & 558.3 & 1034.2 & 1029.0 & 583.8 & 682.8 & 565.4 \\
\hline $\mathrm{Sr}$ & 1.56 & 1.49 & 1.85 & 2.66 & 2.81 & 1.53 & 5.03 & 3.74 & 4.64 \\
\hline Y & 0.47 & 0.23 & 0.28 & 0.07 & 37.64 & 21.55 & 0.06 & 0.11 & 0.58 \\
\hline $\mathrm{Zr}$ & 1.69 & 0.97 & 1.58 & 2.68 & 10.86 & 2.95 & 2.70 & 2.64 & 3.30 \\
\hline $\mathrm{Nb}$ & 56.48 & 126.5 & 119.0 & 86.97 & 227.8 & 125.9 & 80.68 & 81.90 & 76.64 \\
\hline $\mathrm{Sn}$ & 11.37 & 10.68 & 10.22 & 48.26 & 30.53 & 18.64 & 66.24 & 58.74 & 63.67 \\
\hline Cs & 31.14 & 30.84 & 29.31 & 4.54 & 36.17 & 36.18 & 5.45 & 7.63 & 5.42 \\
\hline $\mathrm{Ba}$ & 2133.1 & 1996.4 & 1946.7 & 231.8 & 162.2 & 179.4 & 246.1 & 284.0 & 235.9 \\
\hline $\mathrm{La}$ & 0.14 & 0.04 & 0.03 & bdl & 7.19 & 3.00 & bdl & bdl & 0.11 \\
\hline $\mathrm{Ce}$ & 0.29 & 0.05 & 0.10 & bdl & 6.51 & 3.11 & bdl & bdl & 0.11 \\
\hline $\operatorname{Pr}$ & 0.04 & bdl & 0.02 & bdl & 1.98 & 0.88 & bdl & bdl & 0.03 \\
\hline $\mathrm{Nd}$ & 0.14 & bdl & bdl & bdl & 9.40 & 4.33 & bdl & bdl & 0.09 \\
\hline $\mathrm{Sm}$ & bdl & bdl & bdl & bdl & 2.25 & 1.13 & bdl & bdl & bdl \\
\hline $\mathrm{Eu}$ & 0.07 & 0.05 & 0.06 & 0.03 & 0.38 & 0.21 & 0.04 & 0.04 & 0.05 \\
\hline $\mathrm{Gd}$ & 0.13 & bdl & 0.08 & bdl & 3.52 & 1.88 & bdl & bdl & bdl \\
\hline $\mathrm{Tb}$ & 0.02 & bdl & bdl & bdl & 0.62 & 0.35 & bdl & bdl & bdl \\
\hline Dy & 0.13 & bdl & bdl & bdl & 4.28 & 2.42 & bdl & bdl & 0.07 \\
\hline Ho & 0.03 & bdl & bdl & bdl & 0.93 & 0.53 & bdl & bdl & bdl \\
\hline $\mathrm{Er}$ & 0.10 & 0.04 & 0.04 & bdl & 2.58 & 1.39 & bdl & bdl & 0.06 \\
\hline $\mathrm{Tm}$ & bdl & bdl & bdl & bdl & 0.37 & 0.17 & bdl & bdl & 0.01 \\
\hline $\mathrm{Yb}$ & 0.08 & bdl & bdl & 0.06 & 2.38 & 1.03 & 0.09 & 0.11 & 0.11 \\
\hline $\mathrm{Lu}$ & 0.02 & bdl & bdl & 0.02 & 0.33 & 0.14 & bdl & 0.02 & 0.04 \\
\hline $\mathrm{Hf}$ & 0.12 & 0.08 & 0.07 & 0.17 & 0.58 & 0.21 & 0.18 & 0.19 & 0.29 \\
\hline $\mathrm{Ta}$ & 3.25 & 11.73 & 9.14 & 2.88 & 10.33 & 6.01 & 2.05 & 2.54 & 2.22 \\
\hline W & 11.84 & 11.71 & 12.23 & 51.25 & 4.65 & 5.34 & 103.4 & 68.53 & 73.84 \\
\hline${ }^{208} \mathrm{~Pb}$ & 3.91 & 3.55 & 3.58 & 1.54 & 3.56 & 2.08 & 3.22 & 2.21 & 2.73 \\
\hline $\mathrm{Nb} / \mathrm{Ta}$ & 17.37 & 10.78 & 13.02 & 30.22 & 22.06 & 20.95 & 39.33 & 32.29 & 34.59 \\
\hline
\end{tabular}

$b d l$ below detection limit, $B t$ biotite, $M s$ muscovite 
(Table A3). Trace element concentrations in biotite from the paragneiss account for $>90 \%$ of the whole-rock $\mathrm{Li}, \mathrm{Rb}$, $\mathrm{Nb}, \mathrm{Cs}$, Ta, W concentrations and for $>80 \%$ of the $\mathrm{Sn}$. In the $\mathrm{Og}$, biotite also contains significant and dispersed concentrations of Li ( 58-209 ppm), Rb ( 558-1034 ppm), $\mathrm{Nb}(\sim 87-228 \mathrm{ppm}), \mathrm{Sn}, \mathrm{Cs} \mathrm{Ta}(\sim 3-10 \mathrm{ppm})$ and $\mathrm{W}$ (Table 3). Muscovite has lower and more homogeneous $\mathrm{Li}$ ( 74-87 ppm), Rb ( 565-683 ppm), Nb ( 77-82 ppm), Cs ( 5-8 ppm), Ta ( 2-3 ppm) and higher Sn ( 59-66 ppm) and W ( 69-103 ppm) than biotite, although, for Li and Rb, concentrations overlap. Concerning the other major phases,

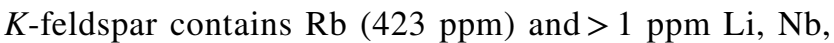
Sn, Cs and W, plagioclase Li (17 ppm) and Rb (123 ppm), quartz $>1 \mathrm{ppm} \mathrm{Rb}$ and $\mathrm{Sn}$ and garnet Li (46 ppm), Rb (94 ppm), Cs (8 ppm) plus $>1$ ppm Sn (Table A3).

In the orthogneiss, $>90 \%$ of the whole-rock $\mathrm{Rb}, \mathrm{Nb}, \mathrm{W}$ and $>70 \%$ of Ta reside in micas. However, the mica Li, Cs and $\mathrm{Sn}$ concentrations are globally too low to match the orthogneiss whole-rock analysis. Only $25 \%$ of the wholerock $\mathrm{Li}$ and $<10 \%$ of the $\mathrm{Cs}$ and $\mathrm{Sn}$ reside in micas. These deficits cannot be fulfilled by local concentration spikes in muscovite which, despite intensive search, were not found. In the same way, Sn-carriers (e.g., Fe-Ti oxides, titanite) are absent and only a few garnets are present. Thus, the missing trace elements must reside in accessory phases, either inclusions or secondary minerals. It is worth recalling that both the mineralogical and geochemical features of the $\mathrm{Og}$, such as presence of muscovite and peraluminous character, are secondary and derived from metamorphic recrystallization (see Crevola 1987). Garnet commonly appears in FMC orthogneisses developed from early Ordovician granitoids (Lotout et al. 2017). The enriched Og bulk chemistry is interpreted to reflect trace element supply by metamorphic fluids and their trapping in major and accessory phases (e.g., Cuney and Barbey 2014). The accessory phase assemblage probably includes white mica given the unusually high $\mathrm{Li}$, $\mathrm{Rb}$ and $\mathrm{Cs}$ concentrations analyzed in garnet. Cassiterite microcrystals are also likely to be involved to match the elevated whole-rock Sn content (218 ppm, Table 1).

\section{Partial melting textures and microtextures}

For the two temperatures $\left(800,850{ }^{\circ} \mathrm{C}\right)$ investigated, both the $\mathrm{Og}$ and the $\mathrm{Pg}$ underwent partial melting. The two starting rocks yielded quite contrasted melting textures at the millimetre to centimetre scale; whereas, at smaller scales $(1-100 \mu \mathrm{m})$, microtextures are similar.

Paragneiss. In the $\mathrm{Pg}$ charges at 800 and $850{ }^{\circ} \mathrm{C}$, melt forms small lenses and filaments distributed at grain boundaries. Element distribution maps emphasize the homogeneity of melt repartition in the reacted core and the continuity of melt films over distances of several hundreds of $\mu \mathrm{m}$. The distribution of the melt network is not influenced by the pre-existing microstructure and foliation. Widths of melt films increase from 800 to $850{ }^{\circ} \mathrm{C}$ (Fig. 2) and melt proportions determined from image analysis range from $\sim 8 \mathrm{vol} \%$ at $800{ }^{\circ} \mathrm{C}$ to $\sim 18 \mathrm{vol} \%$ at $850{ }^{\circ} \mathrm{C}$. At smaller scales, at $800{ }^{\circ} \mathrm{C}$, biotite is largely residual $\left(\mathrm{Bt}_{\text {res }}\right.$ in Fig. 3a-c), only showing incipient reaction to glass plus hercynitic spinel $\left(\mathrm{Spl}_{\mathrm{per}}\right)$ and ilmenite $\left(\mathrm{Ilm}_{\mathrm{per}}, \mathrm{Fig} .3 \mathrm{c}\right)$, whereas the rare muscovites present in the $\mathrm{Pg}$ are extensively transformed (Fig. 3a). Muscovite breaks down to melt plus peritectic phases which include biotite $\left(\mathrm{Bt}_{\text {per }}\right)$, $\mathrm{Spl}_{\text {per }}, \mathrm{Ilm}_{\mathrm{per}}$ and aluminum silicates, the latter comprising mullite (Mul ${ }_{\text {per }}$ ) and possibly sillimanite ( $\mathrm{Sil}_{\text {per }}$, Fig. 3a). Quartz and plagioclase are rounded, generally surrounded by melt and, together with garnet, are interpreted as residual $\left(\mathrm{Qz}_{\mathrm{res}}, \mathrm{Grt}_{\mathrm{res}}\right.$, Fig. 3b, c). At $850^{\circ} \mathrm{C}$, biotite shows more rounded edges and larger melt pools, distributed along cleavages, than at $800{ }^{\circ} \mathrm{C}$. Biotite show more advanced transformation marked by the appearance of peritectic hercynitic spinel $\left(\mathrm{Spl}_{\mathrm{per}}\right)$, orthopyroxene $\left(\mathrm{Opx}_{\mathrm{per}}\right)$ and ilmenite $\left(\mathrm{Ilm}_{\mathrm{per}}\right)$ distributed around and inside residual biotite $\left(\mathrm{Bt}_{\mathrm{res}}\right.$ Fig. 3d, e). Quartz and plagioclase are residual (Fig. 3d-f) and alkali feldspar occurs both as a residual $\left(\mathrm{Kfs}_{\mathrm{res}}\right)$ and peritectic $\left(\mathrm{Kfs}_{\mathrm{per}}\right)$, forming euhedral overgrowths on residual plagioclase (Fig. 3e). Garnet is more reacted at 850 than at $800{ }^{\circ} \mathrm{C}$ and, when close to biotite, can develop overgrowths with inclusions of ilmenite needles suggesting a locally peritectic origin ( $\mathrm{Grt}_{\text {per }}$, Fig. 3f).

Orthogneiss. At both 800 and $850{ }^{\circ} \mathrm{C}$, melt pools are heterogeneously distributed and preferentially associated with muscovite reaction zones pre-localized in the micarich layers (Fig. 4). Melt proportions from image analysis range from $\sim 13 \mathrm{vol} \%$ at $800{ }^{\circ} \mathrm{C}$ to $\sim 20$ vol $\%$ at $850{ }^{\circ} \mathrm{C}$. At smaller scale, at $800{ }^{\circ} \mathrm{C}$, muscovite is entirely consumed while scarce residual biotites are preserved. Muscovite is entirely replaced by glass plus fine-grained peritectic phases $\left(\mathrm{Bt}_{\mathrm{per}}, \mathrm{Spl} \mathrm{per}_{\mathrm{per}}, \mathrm{Ilm}_{\mathrm{per}}, \mathrm{Mul}_{\mathrm{per}}, \mathrm{Sil}_{\mathrm{per}}\right)$ and only muscovite "ghosts" can be recognized (Fig. 5a). Peritectic ilmenite is stocky to acicular $(<5 \mu \mathrm{m})$ whereas biotite $(<5 \mu \mathrm{m})$ and hercynitic spinel (up to $5 \mu \mathrm{m}$ ) are euhedral to subhedral, sillimanite is acicular and, mullite, skeletal (Fig. 5b). Spinel and biotite form chaplets that underline the former muscovite cleavage while sillimanite and mullite are more clustered (Fig. 5d). Euhedral K-feldspar $\left(\mathrm{Kfs}_{\mathrm{per}}\right)$ crystallizes as overgrowths on residual feldspars $\left(\mathrm{Pl}_{\text {res }}\right.$ and $\left.\mathrm{Kfs}_{\text {res }}\right)$ and residual quartz shows rounded shapes ( $\mathrm{Qz}_{\text {res }}$, Fig. 5c). At $850{ }^{\circ} \mathrm{C}$, muscovite is totally consumed and biotite undergoes incipient breakdown. Muscovite is replaced by melt plus the same peritectic phases as at $800{ }^{\circ} \mathrm{C}$ (Fig. 5e). Residual biotite $\left(\mathrm{Bt}_{\mathrm{res}}\right)$ is associated with peritectic orthopyroxene $\left(\mathrm{Opx}_{\mathrm{per}}\right)$ in addition to hercynitic spinel $\left(\mathrm{Spl}_{\text {per }}\right)$ and ilmenite ( $\mathrm{Ilm}_{\text {per }}$, Fig. 5f). Orthopyroxenes have sizes from several to tens $\mu \mathrm{m}$ and occur as 
Fig. 2 Large-scale textures and melt distributions in $\mathrm{Pg}$ charges at a $800{ }^{\circ} \mathrm{C}$ and $\mathbf{b} 850{ }^{\circ} \mathrm{C}$. The top views are SEM panoramas and the middle views show the corresponding assemblage distributions. Melt proportions $\left(\sim 8 \%\right.$ at $800{ }^{\circ} \mathrm{C}, \sim 18 \%$ at $850{ }^{\circ} \mathrm{C}$ ) are calculated from the number of pixels for the different assemblages (melt zones: orange, melt + peritectic phases: dark gray, restite: light gray). See text for additional information. Note that both melt and melt + peritectic phases distribute along a continuous network at grain boundaries
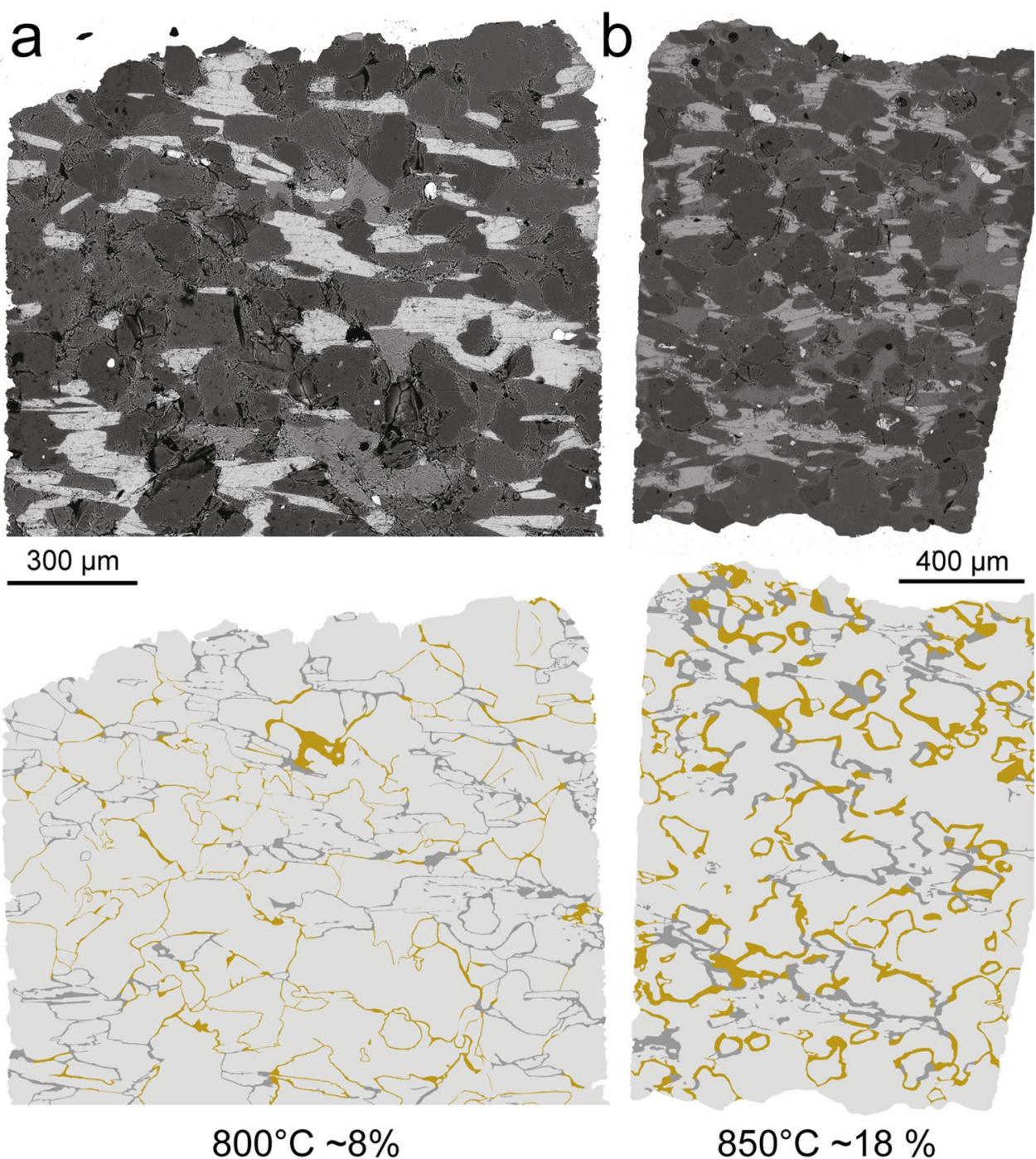

$850^{\circ} \mathrm{C} \sim 18 \%$

\section{Restite}

Melt + peritectic phases elongated stocky crystals growing perpendicular to edges of residual biotite (Fig. 5f).

\section{Experimental phase compositions}

Glasses. Representative individual analyses and averages are reported for the four charges (Table 4; Fig. 6). Experimental glasses are relatively homogeneous. However, a minor chemical heterogeneity is apparent, e.g., for $\mathrm{Al}_{2} \mathrm{O}_{3}$, the standard deviation of the population of analyses is, in the four glasses, slightly higher than the analytical error (2-2.6\% vs. $1-1.5 \%$, see above). This is also true for $\mathrm{Na}_{2} \mathrm{O}$ (6.9-16.6\% vs. $2-3.5 \%)$ and, in some glasses, for $\mathrm{SiO}_{2}, \mathrm{CaO}$ and $\mathrm{K}_{2} \mathrm{O}$ (Fig. 6). Migration of alkali especially $\mathrm{Na}$ under the electron beam was not corrected for (e.g., Pichavant et al. 1987). Underestimation of Na would artificially increase A/
CNK. However, glasses from the four charges should be impacted uniformly since they differ compositionally very little and, so, the conclusions below should be unaffected. Electron microprobe analyses sum to between 94 and 97 wt $\%$ which corresponds to $\mathrm{H}_{2} \mathrm{O}$ concentrations of $\sim 4 \%$ with the by-difference method (Villaros et al. 2018b).

Glasses from the four charges are all very similar, being $\mathrm{SiO}_{2}$ rich (74.0-76.3 wt\%, Table 4; Fig. 6) and more peraluminous and felsic than the two starting rocks (see Table 1). $\mathrm{A} / \mathrm{CNK}, A^{*}$ and $B^{*}$ extend to higher values in $\mathrm{Pg}(1.20-1.46$, $38-86$ and $23-37$, respectively) than in Og glasses (1.25-1.36, 46-67 and 18-29, Table 4). The latter are the most $\mathrm{K}_{2} \mathrm{O}$ - and $\mathrm{Na}_{2} \mathrm{O}$ rich, consistent with the respective compositions of the starting rocks. $\mathrm{CaO}$ concentrations are uniform and very low (0.3-0.4 wt\%, Table 4). Upon increasing the temperature and the degree of melting, glasses in 

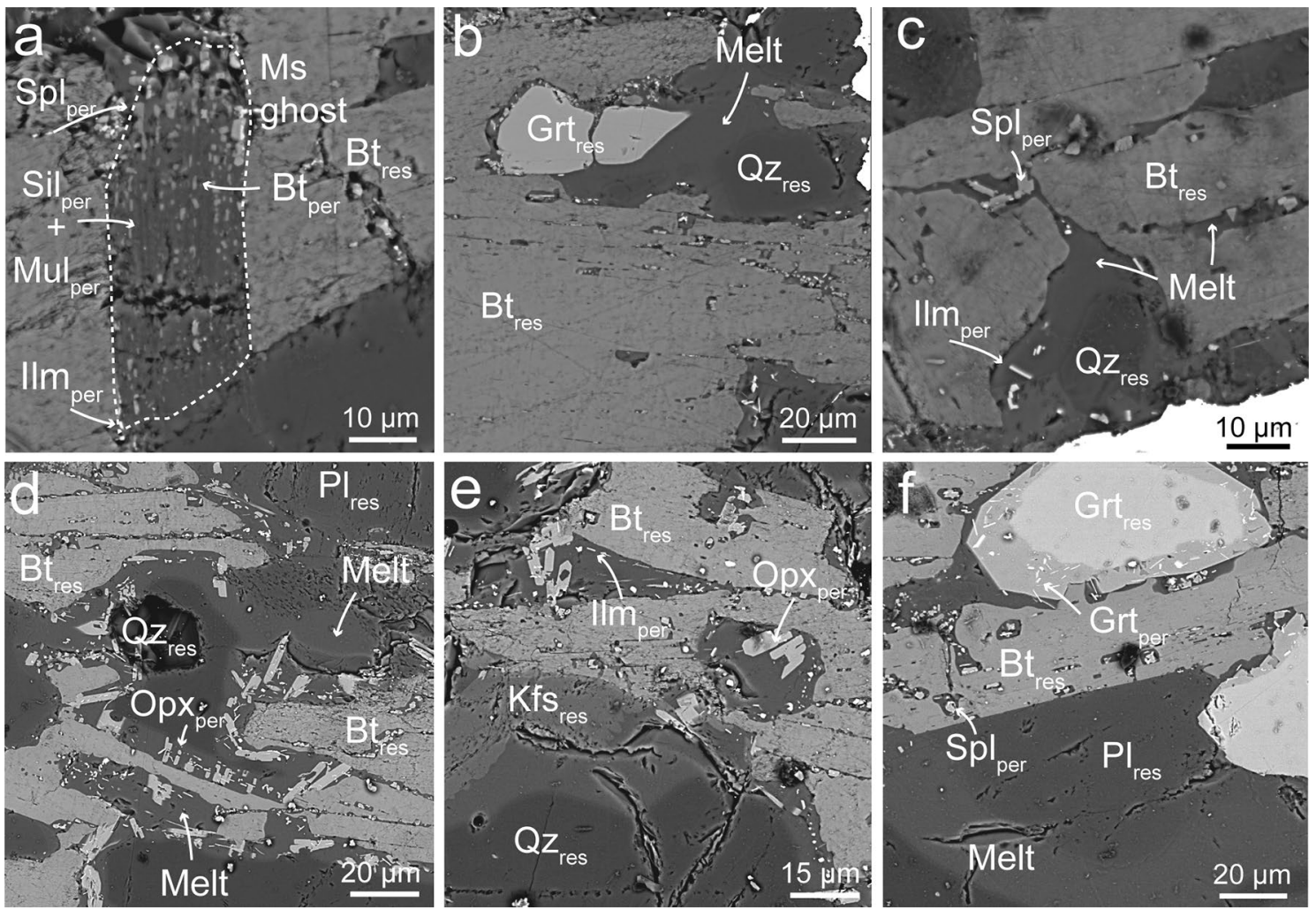

Fig. 3 BSE images showing microtextures in Pg charges at $800{ }^{\circ} \mathrm{C}$ $(\mathbf{a}-\mathbf{c})$ and $850{ }^{\circ} \mathrm{C}(\mathbf{d}-\mathbf{f})$. a Reacted muscovite "ghost" with melt and peritectic phases including biotite $\left(\mathrm{Bt}_{\mathrm{per}}\right)$, sillimanite and/or mullite $\left(\mathrm{Sil}_{\text {per }}, \mathrm{Mul}_{\text {per }}\right)$, spinel $\left(\mathrm{Spl}_{\text {per }}\right)$ and ilmenite $\left(\mathrm{Ilm}_{\text {per }}\right)$. b Largely unreacted biotite $\left(\mathrm{Bt}_{\mathrm{res}}\right)$ hosting only a few small melt pools with small peritectic phases. Note the rounded edges of residual quartz $\left(\mathrm{Qz}_{\mathrm{res}}\right)$

both groups become more $\mathrm{K}_{2} \mathrm{O}-, \mathrm{CaO}-$ and $\mathrm{FeO}$ rich and less peraluminous. Glass $\mathrm{FeOt} / \mathrm{MgO}$ ratios also slightly increase with temperature, consistent with peritectic phases becoming more magnesian at $850{ }^{\circ} \mathrm{C}$ (see below). However, these changes are minor, being in the same range or smaller than the standard deviations.

Concentrations of selected trace elements $(\mathrm{Li}, \mathrm{Rb}, \mathrm{Nb}$, $\mathrm{Sn}, \mathrm{Cs}, \mathrm{Ta}, \mathrm{W}$ ) in experimental glasses (hereafter designated $C_{\text {melt }}$ ) are given in Table 5 and the data are illustrated in Fig. 7, where $\mathrm{Rb}$ is used as a differentiation index. Most data are for the $\mathrm{Og} 800$ and $850{ }^{\circ} \mathrm{C}$ charges and a laser spot size of $15 \mu \mathrm{m}$, although, at $850{ }^{\circ} \mathrm{C}$, data with a $50 \mu \mathrm{m}$ spot were also obtained (Table 5). The raw data were filtered from examination of the 21 measured isotope concentrations (to check glass contamination by mineral phases) and from post-analysis SEM imaging of the charges (to check locations of analytical pits). For the $800{ }^{\circ} \mathrm{C} \mathrm{Og}$, only 7 analyses out of 24 spots were retained, and 7 out of 16 for the $850{ }^{\circ} \mathrm{C}$ (Table 5). For Pg charges, glass films were generally too thin for LA-ICP-MS analysis and 2 analyses out of 11 spots are available at $850{ }^{\circ} \mathrm{C}$. Both individual and median $\mathrm{C}_{\text {melt }}$ (instead of mean values and the unreacted garnet $\left(\mathrm{Gt}_{\mathrm{res}}\right)$. (c) Slightly reacted $\mathrm{Bt}_{\mathrm{res}}$ and $\mathrm{Qz}_{\text {res }}$. Note the presence of $\mathrm{Spl}_{\mathrm{per}}$ and $\mathrm{Ilm}_{\mathrm{per}}$ in melt pools. d, e Reaction of biotite to form peritectic orthopyroxene $\left(\mathrm{Opx}_{\mathrm{per}}\right), \mathrm{Spl}_{\mathrm{per}}$ and $\mathrm{Ilm}_{\mathrm{per}}$. Feldspars $\left(\mathrm{Kfs}_{\text {per, }}, \mathrm{Pl}_{\text {per }}\right)$ appear mainly residual. f Overgrowth of peritectic garnet $\left(\mathrm{Gt}_{\mathrm{per}}\right)$ on residual garnet $\left(\mathrm{Gt}_{\mathrm{res}}\right)$ showing abundant ilmenite inclusions in $\mathrm{Gt}_{\text {per }}$

to avoid giving too much weight to outliers) are plotted (Fig. 7). In the $800^{\circ} \mathrm{C} \mathrm{Og}, \mathrm{Li}$ contents range from 62.0 to $103.9 \mathrm{ppm}, \mathrm{Rb}$ from 349.2 to $485.0 \mathrm{ppm}, \mathrm{Nb}$ from 28.06 to $51.81 \mathrm{ppm}$, Cs from 5.20 to $19.14 \mathrm{ppm}$, Ta from 0.43 to $3.89 \mathrm{ppm}$, W from 23.35 to $52.56 \mathrm{ppm}$ and $\mathrm{Nb} / \mathrm{Ta}$ from 13.3 to 83.6 (Table 5). At $850^{\circ} \mathrm{C}$, the data are more clustered for some elements (57.5-119.4 ppm Li, 400.1-464.0 ppm Rb, 27.09-44.62 ppm Nb, 10.41-18.56 ppm Cs, 0.55-1.89 ppm $\mathrm{Ta}, 18.26-37.94 \mathrm{ppm} \mathrm{W}, \mathrm{Nb} / \mathrm{Ta}$ from 21.5 to 45.2 , Table 5). $\mathrm{Sn}$ is always very low $\left(\mathrm{Og}\right.$ glasses: $<9.33 \mathrm{ppm}$ at $800{ }^{\circ} \mathrm{C}$ and $<15.15 \mathrm{ppm}$ at $850{ }^{\circ} \mathrm{C} ; \mathrm{Pg} 850^{\circ} \mathrm{C}$ glasses: $<2.20 \mathrm{ppm}$ ). Glasses from the two protoliths are chemically contrasted as illustrated by the higher Li (167.7-197.6 ppm) in the $\mathrm{Pg}$ than in the $\mathrm{Og}(57.5-119.4 \mathrm{ppm})$ and the higher $\mathrm{Rb}$ (400.1-464.0 ppm) in the $\mathrm{Og}$ than the in $\mathrm{Pg}$ (250.5-273.1 ppm, data at $850{ }^{\circ} \mathrm{C}$, Table 5; Fig. 7). Ta concentrations are $<2 \mathrm{ppm}$ (except one outlier in the $\mathrm{Og}$ at $800{ }^{\circ} \mathrm{C}$ ) and similar in both glass groups. The Og are globally enriched in $\mathrm{Rb}, \mathrm{Nb}, \mathrm{Ta}, \mathrm{W}$ and depleted in $\mathrm{Li}$ and $\mathrm{Cs}$ compared to the source rock. The Pg are strongly enriched in $\mathrm{Li}$, less so in $\mathrm{Rb}, \mathrm{Cs}$ and $\mathrm{W}$, whereas both $\mathrm{Nb}$ and $\mathrm{Ta}$ are depleted. $\mathrm{Nb} / \mathrm{Ta}$ in the $\mathrm{Og}$ (median $C_{\text {melt }}=29.0$ and 27.4 at 


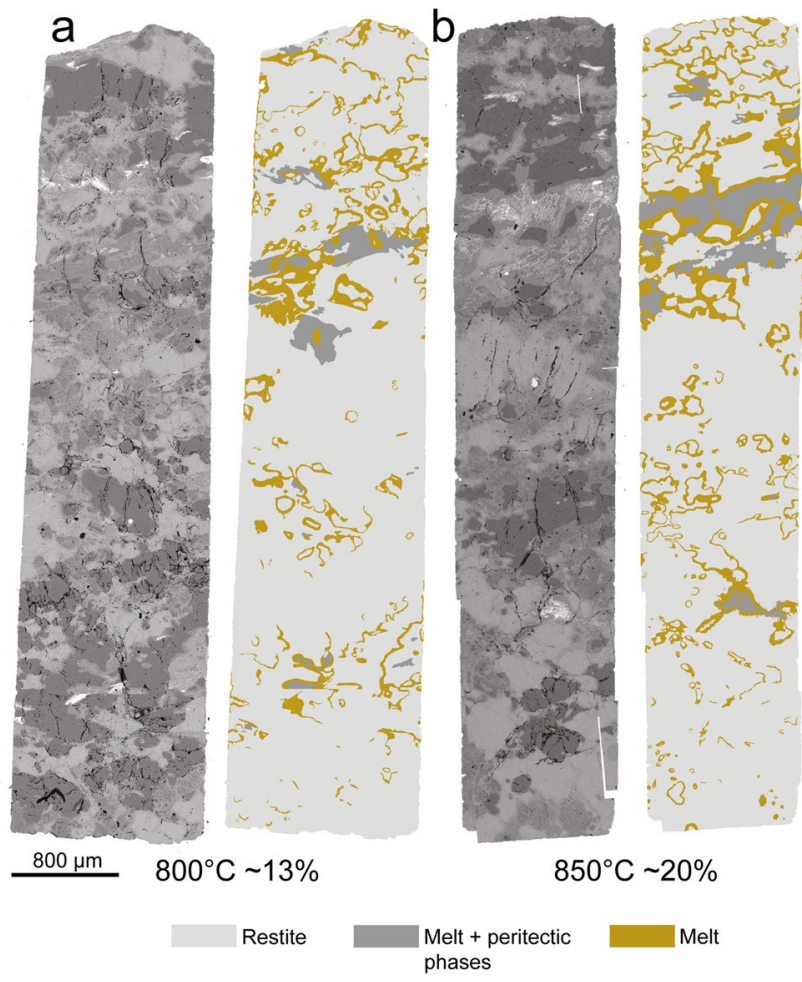

Fig. 4 Large-scale textures and melt distributions in Og charges at a $800{ }^{\circ} \mathrm{C}$ and b $850{ }^{\circ} \mathrm{C}$. For each temperature, SEM panoramas are on the left and assemblage distributions on the right. Calculated melt proportions are $\sim 13 \%$ at $800{ }^{\circ} \mathrm{C}$ and $\sim 20 \%$ at $850{ }^{\circ} \mathrm{C}$. Note that melt (orange zones) and melt + peritectic phases (dark gray zones) are heterogeneously distributed and concentrate in muscovite reaction zones. See text for additional information

800 and $\left.850^{\circ} \mathrm{C}\right)$ and in $\mathrm{Pg}(13.6$, Table 5) glasses are higher than in source rocks (respectively, 12.0 and 9.4, Table 1).

Peritectic phases. Major element compositions of peritectic phases are available in all charges (Tables A4-A6) except the $800{ }^{\circ} \mathrm{C} \mathrm{Pg}$ because reactions are limited and products, too small for electron microprobe analysis (Fig. 3a, c). Orthopyroxenes $\left(\mathrm{Opx}_{\mathrm{per}}\right)$ at $850{ }^{\circ} \mathrm{C}$ are more magnesian $(\mathrm{Mg} \#=$ at. $\mathrm{Mg} /(\mathrm{Mg}+\mathrm{Fe})=0.44-0.53)$ in the Pg than in the Og charge $(\mathrm{Mg} \#=0.19)$, consistent with the respective biotite compositions in the protoliths (Table 2), and $\mathrm{CaO}$ contents are very low $(<0.1 \%$ Wo $)$. Hercynites $\left(\mathrm{Spl}_{\text {per }}\right)$ also extend to higher $\mathrm{Mg} \#$ in $\mathrm{Pg}$ than in Og charges (respectively, $0.34-0.35$ vs. $0.22-0.23$ at $850^{\circ} \mathrm{C}$ ) and their $\mathrm{Mg} \#$ decrease with temperature $\left(0.10-0.21\right.$ in the $\mathrm{Og}$ charge at $\left.800^{\circ} \mathrm{C}\right)$. $\mathrm{Fe}^{3+} / \mathrm{Fe}_{\text {tot }}$ at. proportions in $\mathrm{Spl}_{\text {per }}$ are mostly between 2 and 9\% with no difference between charges. Peritectic biotites $\left(\mathrm{Bt}_{\mathrm{per}}\right)$ in $\mathrm{Og}$ charges are more magnesian $(\mathrm{Mg} \#=0.43-0.49)$ and richer in $\mathrm{Al}$ and $\mathrm{Ti}$ (Table $\mathrm{A} 5, \mathrm{~A} 6$ ) than in the starting rock whereas residual biotites $\left(\mathrm{Bt}_{\text {res }}\right)$ in the $850{ }^{\circ} \mathrm{C} \mathrm{Pg}$ charge stay chemically unchanged. Ilmenites (compositions in Og charges only, $\mathrm{Ilm}_{\text {per }}$ in Pg charges could not be reliably analyzed due to their small size) have $\mathrm{Mg \#} \sim 0.05$ and a maximum of $3 \% \mathrm{Fe}_{2} \mathrm{O}_{3}$. Al silicates $\left(\mathrm{Sil}_{\text {per }}\right.$ and $\left.\mathrm{Mul}_{\text {per }}\right)$ almost exclusively contain $\mathrm{Al}_{2} \mathrm{O}_{3}$ and $\mathrm{SiO}_{2}$ but $\mathrm{Al} / \mathrm{Si}$ at. Ratios are variable from $\sim 1$ to $>>1$, i.e., from sillimanite to mullite compositions. Peritectic K-feldspar $\left(\mathrm{Kfs}_{\text {per }}\right)$ is in the range $\mathrm{Or}_{59-73} \mathrm{Ab}_{26-37} \mathrm{An}_{2-4}$, always more $\mathrm{Na}$ rich and $\mathrm{K}$ poor than in the protoliths (Tables A4-A6). In the $850{ }^{\circ} \mathrm{C}$ Pg charge, $\mathrm{Kfs}_{\text {per }}$ contains $\sim 2 \mathrm{wt} \% \mathrm{BaO}$ (Table A4). Garnet overgrowths in the $850{ }^{\circ} \mathrm{C} \mathrm{Pg}$ charge (Fig. 3f) are strongly enriched in $\mathrm{Mg}$ and depleted in $\mathrm{Mn}$ and Ca compared to preexisting crystals (Tables A2, A4).

The peritectic phases were too small to be analyzed individually for trace elements. Yet, analyses of glass-peritectic phase mixtures from muscovite reaction zones in $\mathrm{Og}$ charges constrain the rare element concentrations of peritectic assemblages. A total of 16 analyses are available at $800{ }^{\circ} \mathrm{C}$ and 3 at $850{ }^{\circ} \mathrm{C}$ (Table 6). Concentrations in mixtures $\left(C_{\text {mix }}\right)$ are plotted together with $C_{\text {melt }}$ for comparison (Fig. 7). Enrichments/depletions in mixtures relative to glass (fractionation factor, $f=C_{\text {mix }}$ (Table 6)/median $C_{\text {melt }}$ (Table 5)) are quite dispersed because peritectic assemblages in mixtures have variable modal compositions (Fig. 5; Table A7), some being rich in $\mathrm{Sil}_{\text {per }}$ plus $\mathrm{Mul}_{\text {per }}$ and other dominated by ferromagnesian phases $\left(\mathrm{Bt}_{\mathrm{per}}, \mathrm{Spl}_{\mathrm{per}}, \mathrm{Ilm}_{\mathrm{per}}\right)$ in different proportions. For $\mathrm{Rb}, \mathrm{f}$ ranges from 0.63 (depleted in mixture) to 1.10 (enriched in mixture), on average 0.90 at $800{ }^{\circ} \mathrm{C}$, slightly higher $(f=0.99)$ and more homogeneous at $850{ }^{\circ} \mathrm{C}$. For $\mathrm{Nb}$ and $\mathrm{Ta}$, most $\mathrm{f}$ are $>1$ (on average $\sim 2$ at $800{ }^{\circ} \mathrm{C}$, increasing to $\sim 3$ at $850{ }^{\circ} \mathrm{C}$ ) indicating enrichments in mixtures. Although scattered ( $f$ from 0.99 to 4.74 for $\mathrm{Nb}$ and from 0.53 to 5.32 for $\mathrm{Ta}$ ), the $\mathrm{Nb}$ and $\mathrm{Ta}$ enrichments are linearly correlated with slopes $<1(0.3$ at 800 and 0.6 at $850{ }^{\circ} \mathrm{C}$ ) indicating preferential incorporation of Ta over $\mathrm{Nb}$ in mixtures. $\mathrm{Nb} / \mathrm{Ta}$ range widely in mixtures, from 12.2 to $72.0\left(800{ }^{\circ} \mathrm{C}\right)$ and 19.9 to $38.3\left(850{ }^{\circ} \mathrm{C}\right.$, Table 6), i.e., from lower to higher than glass medians (29.0 and 27.4 respectively, Table 5). Sn concentrations $>20 \mathrm{ppm}$ (Table 6) are found in a few mixtures which contrasts with the low amounts in glasses. W is commonly, although not systematically, enriched in mixtures $\left(f=0.71-5.67\right.$ at $800{ }^{\circ} \mathrm{C}$, $1.18-2.07$ at $\left.850{ }^{\circ} \mathrm{C}\right)$. Two $\mathrm{W}$ concentrations are very high (above $150 \mathrm{ppm}$, Table 6) and associated with high $\mathrm{Nb}$ and $\mathrm{Ta}$ although the $\mathrm{Nb}-\mathrm{W}$ and $\mathrm{Ta}-\mathrm{W}$ enrichments are poorly correlated suggesting the presence of a specific W-bearing phase in the peritectic assemblage. $\mathrm{Li}$ and $\mathrm{Cs}$ have $\mathrm{f}$ mostly $<1$ and so both are depleted in mixtures compared to glasses. Fractionation factors ranges from 0.11 to 1.43 for $\mathrm{Li}$ (on average 0.64 at $800{ }^{\circ} \mathrm{C}$ and 0.66 at $850{ }^{\circ} \mathrm{C}$ ) and $\mathrm{Cs}$ from 0.31 to 1.72 (on average 0.75 at $800{ }^{\circ} \mathrm{C}$ and 0.79 at $850^{\circ} \mathrm{C}$ ). 

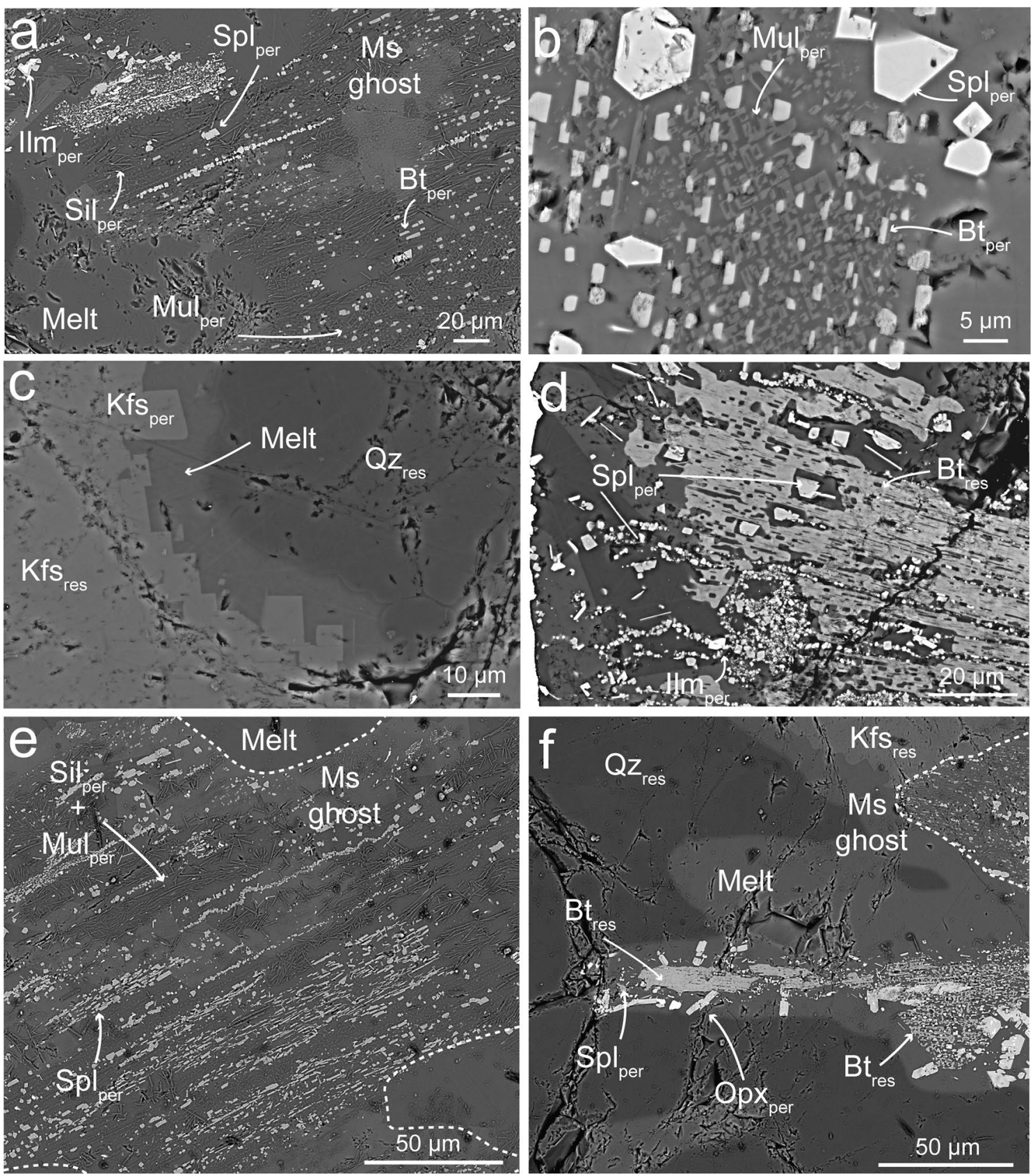

Fig. 5 BSE images showing microtextures in the $\mathrm{Og}$ charges at $800{ }^{\circ} \mathrm{C}(\mathbf{a}-\mathbf{d})$ and $850{ }^{\circ} \mathrm{C}(\mathbf{e}-\mathbf{f})$. a Large-scale view of muscovite reaction zone ("ghost") showing representative breakdown textures and associated peritectic phases including biotite $\left(\mathrm{Bt}_{\text {per }}\right)$, sillimanite and/or mullite $\left(\mathrm{Sil}_{\mathrm{per}}, \mathrm{Mul} \mathrm{per}_{\mathrm{p}}\right)$, spinel $\left(\mathrm{Spl}_{\mathrm{per}}\right)$ and ilmenite $\left(\mathrm{Ilm}_{\mathrm{per}}\right)$. b Higher magnification view detailing the fine-grained peritectic min-

\section{Discussion}

\section{Melting mechanisms and reactions}

As emphasized above, melt distribution is contrasted between Bt-rich Pg and Ms-rich Og charges. Differences in erals and their textures and the interstitial melt. c Peritectic euhedral $\mathrm{K}$-feldspars $\left(\mathrm{Kfs}_{\text {per }}\right)$ overgrowing residual $\mathrm{K}$-feldspars $\left(\mathrm{Kfs}_{\mathrm{res}}\right)$. d Biotite showing limited reaction to $\mathrm{Spl}_{\text {per }}$ and $\mathrm{Ilm}_{\mathrm{per}}$ e Muscovite reaction zone showing a peritectic assemblage and textures similar to (a). f Biotite reacted to peritectic orthopyroxene $\left(\mathrm{Opx}_{\mathrm{per}}\right), \mathrm{Spl}_{\mathrm{per}}$ and $\mathrm{Ilm}_{\mathrm{per}}$. Note the larger melt pools

melting behavior between muscovite- and biotite-bearing lithologies have been previously interpreted in terms of contrasted volume changes and dilatational strains associated with the respective mica dehydration-melting reactions (Rushmer 2001; Holyoke and Rushmer 2002). However, textures suggesting melt overpressure (e.g., melt cracks, 


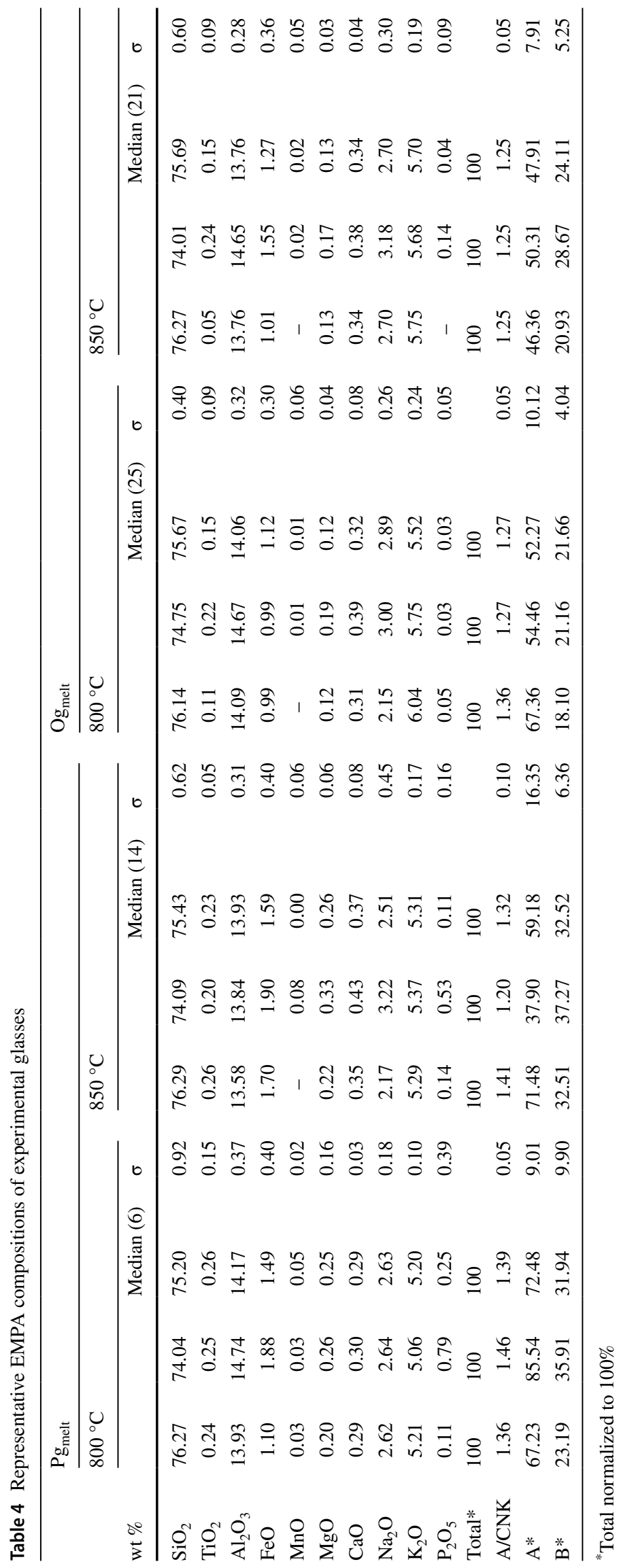



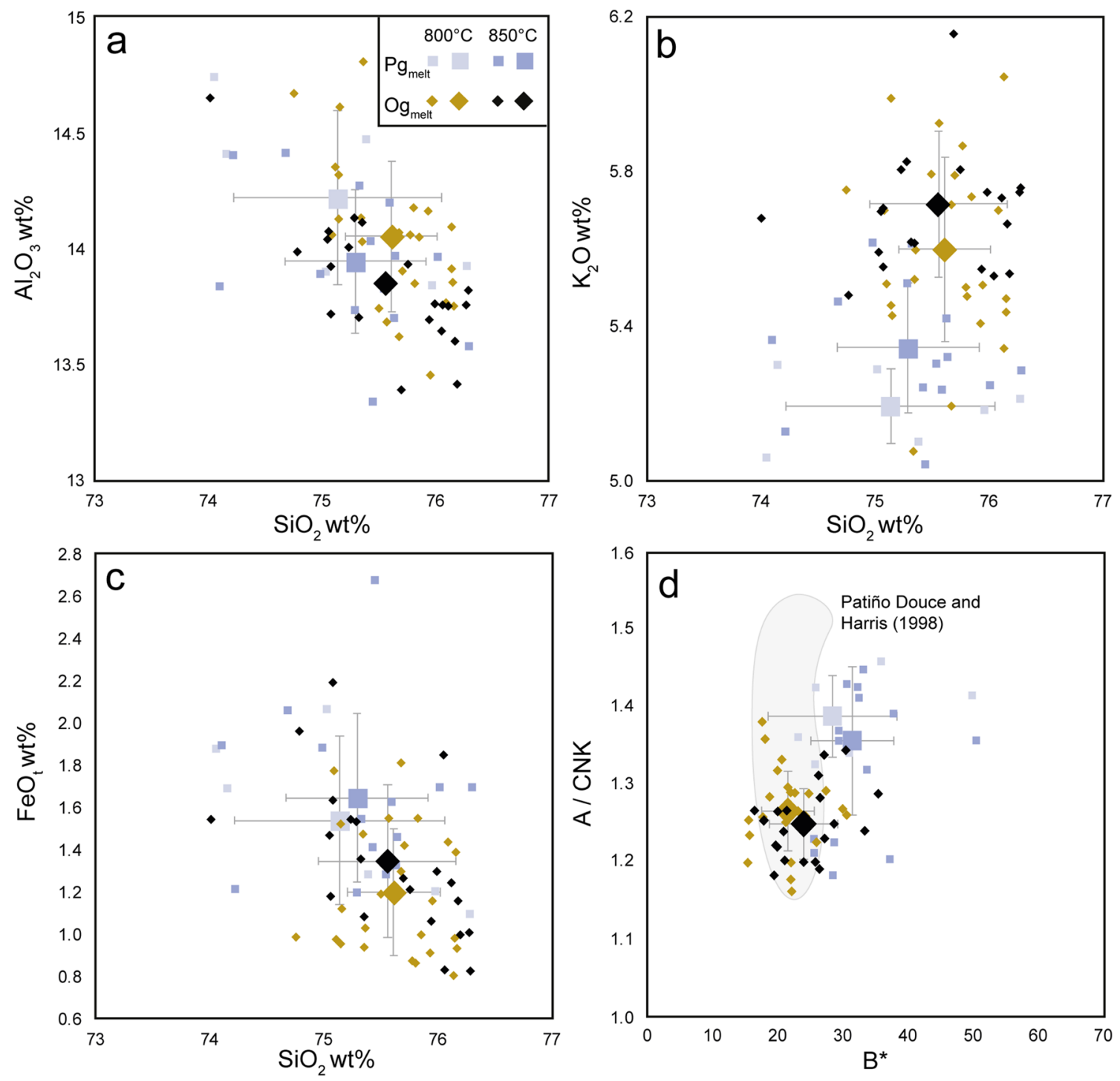

Fig. 6 Major element compositions of experimental melts (paragneiss: $\mathrm{Pg}_{\text {melt }}$; orthogneiss: $\mathrm{Og}_{\text {melt }}$ ). Data from Table 4. The small symbols are individual glass analyses $\left(\mathrm{Pg}_{\text {melt }}\right.$ : light blue at $800{ }^{\circ} \mathrm{C}$, blue at $850{ }^{\circ} \mathrm{C}$; $\mathrm{Og}_{\text {melt }}$ : brown at $800{ }^{\circ} \mathrm{C}$, black at $850{ }^{\circ} \mathrm{C}$ ) and the large symbols represent median values of each of the four populations of analy-

Connolly et al. 1997), although locally present, are not widespread in charges from this study and other mechanisms appear to control the melt distribution.

At $400 \mathrm{MPa}, 800{ }^{\circ} \mathrm{C}$ is well above the muscovite dehydration-melting reaction and in the lower range of the equivalent reaction for biotite (e.g., Spear 1995; Holyoke and Rushmer 2002). $850{ }^{\circ} \mathrm{C}$ is in the middle of the range for biotite dehydration-melting (e.g., Spear 1995; Holyoke and Rushmer 2002). Therefore, most muscovite initially present in starting materials would react out at $800{ }^{\circ} \mathrm{C}$; biotite would show only incipient reaction at this temperature and a more advanced transformation at $850{ }^{\circ} \mathrm{C}$. Textural observations confirm this general behavior. At

ses. (a)-(c) Hacker diagrams showing $\mathrm{Al}_{2} \mathrm{O}_{3}$ (a), $\mathrm{K}_{2} \mathrm{O}$ (b) and $\mathrm{FeO}_{\mathrm{t}}$ (c) plotted against $\mathrm{SiO}_{2}$. In (d), data from Patiño Douce and Harris (1998) are shown for comparison. $\mathrm{A} / \mathrm{CNK}$ is calculated as $\mathrm{Al}_{2} \mathrm{O}_{3} /$ $\left(\mathrm{Na}_{2} \mathrm{O}+\mathrm{K}_{2} \mathrm{O}+\mathrm{CaO}\right)$ molar and $B^{*}$ as 1000 . $\left(\mathrm{Fe}_{\text {tot }}+\mathrm{Mg}+\mathrm{Ti}\right)$ atomic as defined in Table 1

$800{ }^{\circ} \mathrm{C}$, muscovite shows extensive reaction in both $\mathrm{Og}$ (Fig. 5a, b, d) and Pg (Fig. 3a) charges. Peritectic biotite is produced, consistent with limited biotite destabilization (Fig. 3c). At $850{ }^{\circ} \mathrm{C}$, clear evidence for advanced biotite breakdown is provided by the appearance of orthopyroxene in both samples (Fig. 3d, e, 5f). However, residual biotite is still present and, so, the "biotite-out" curve is not overstepped (see Holyoke and Rushmer 2002, their Fig. 3).

In the $800{ }^{\circ} \mathrm{C} \mathrm{Pg}$ charge, the degree of melting is very small (e.g., $\sim 8$ vol\% from image analysis). Muscovite contributes negligibly to melt formation, being present in minor amount in the starting material. Biotite is abundant, homogeneously distributed, and it remains little reacted (Fig. 3c). 


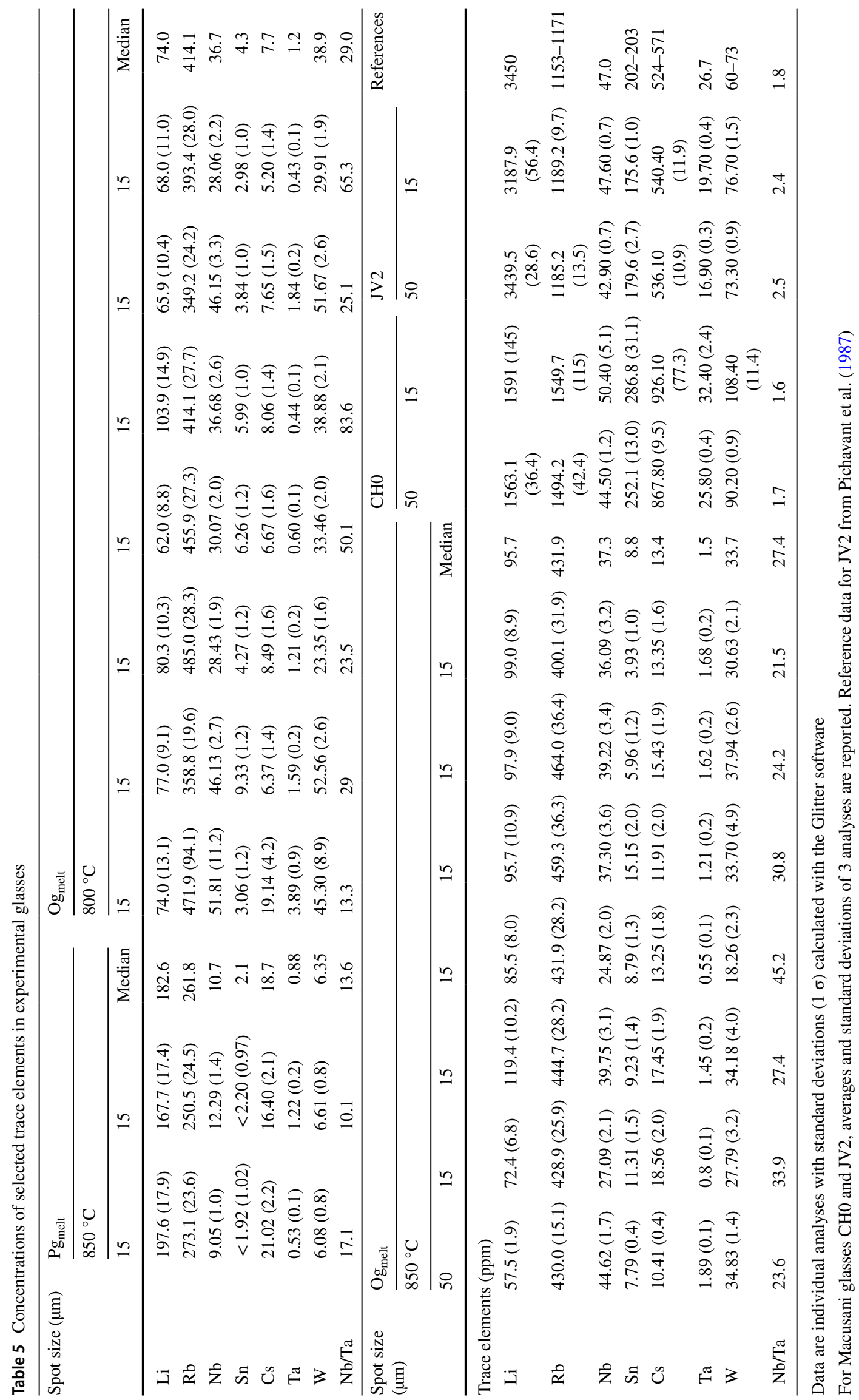



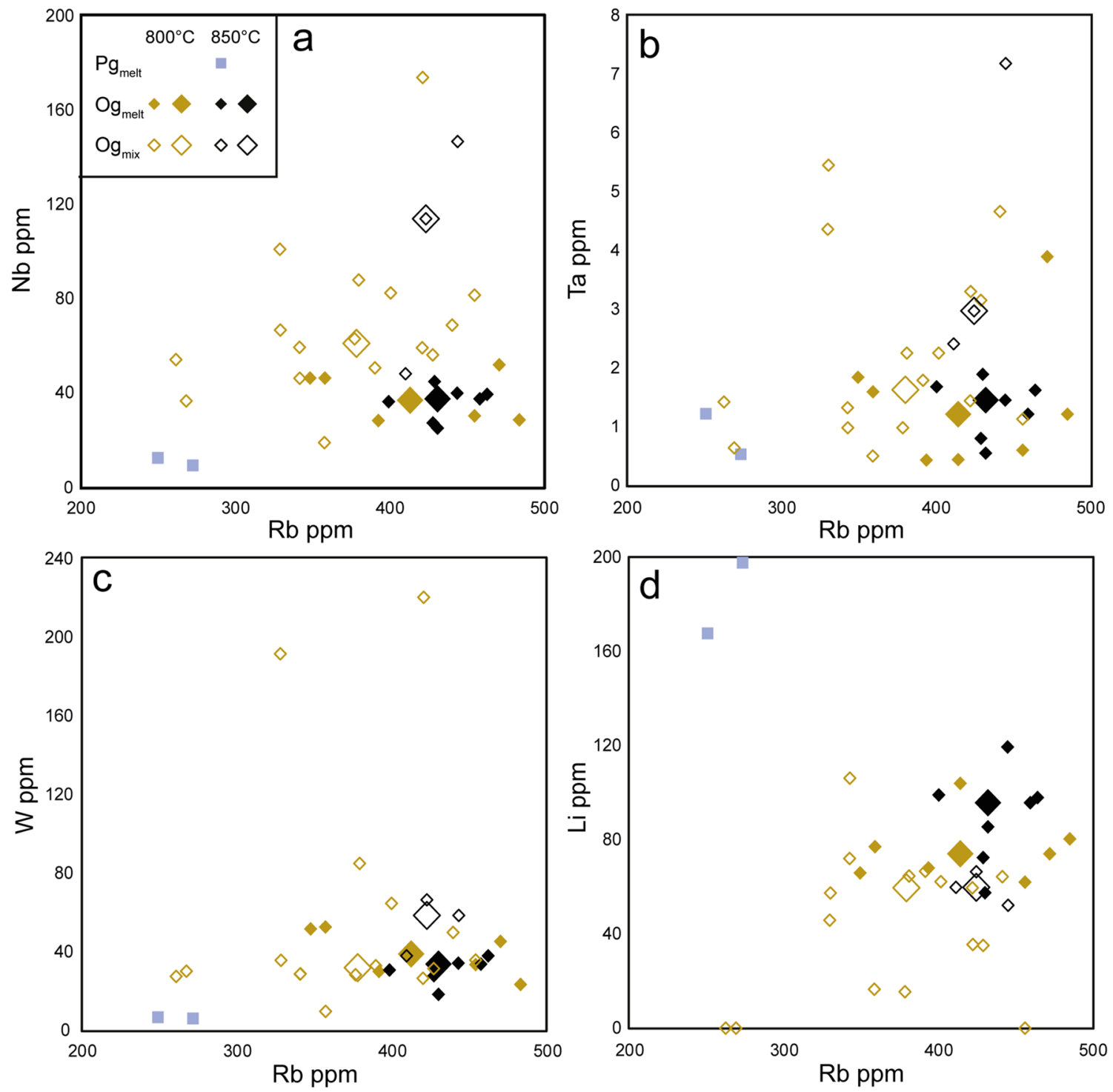

Fig. 7 Trace element compositions of experimental melts (Table 5) and melt-peritectic phases mixtures (Table 6). Only two melt analyses are available for the $\mathrm{Pg}$ at $850{ }^{\circ} \mathrm{C}$ (small blue symbols, $\mathrm{Pg}_{\text {melt }}=\mathrm{C}_{\text {melt }}$ ). For the $\mathrm{Og}$, the solid symbols are for the melt

$\left(\mathrm{Og}_{\text {melt }}=\mathrm{C}_{\text {melt }}\right)$ and the open symbols for the melt-peritectic phases mixtures $\left(\mathrm{Og}_{\text {mix }}=\mathrm{C}_{\text {mix }}\right)$. The small symbols are individual analyses and the large symbols (brown at $800^{\circ} \mathrm{C}$, black at $850{ }^{\circ} \mathrm{C}$ ) represent median values of each of the four populations of analyses

Biotite edges become rounded, melt pools form along cleavages and peritectic spinel and ilmenite (but not orthopyroxene) appear, the reaction mechanism being similar to the one described by Brearley (1987). Therefore, the contribution of biotite to melt formation is very small. It is recalled that, at $400 \mathrm{MPa}$, dry melting of a quartz-two feldspar assemblage requires a minimum temperature of $\sim 980{ }^{\circ} \mathrm{C}$ (Luth 1969; see also Brearley and Rubie 1990; Johannes and Holtz 1996). Since this temperature is much higher than $800{ }^{\circ} \mathrm{C}$ and given that micas are very little reacted, water necessary for melting must be essentially interstitial, present at grain boundaries. Such a water-fluxed mechanism is consistent with the homogeneous melt distribution and the continuous melt

network observed at grain boundaries (Fig. 2). For illustration, assuming $0.1 \mathrm{wt} \%$ interstitial water in the $\mathrm{Pg}$ (a typical metamorphic pore water concentration, Yardley 2009), 5.5 vol $\%$ melt would be generated at $800{ }^{\circ} \mathrm{C}, 500 \mathrm{MPa}$ (Clemens and Vielzeuf 1987; Johannes and Holtz 1996), close to estimated ( $\sim 8 \mathrm{vol} \%$ melt). Therefore, the reaction describing melting in the $\mathrm{Pg}$ at $800{ }^{\circ} \mathrm{C}$ is written as:

$\mathrm{Bt}_{\text {res }}+\mathrm{Qz}_{\text {res }}+\mathrm{Pl}_{\text {res }}+\mathrm{Kfs}_{\text {res }} \pm \mathrm{Grt}_{\mathrm{res}} \pm \mathrm{Ky}_{\text {res }} \pm \mathrm{Ms}+\mathrm{H}_{2} \mathrm{O} \rightarrow$ Melt,

where "res" refers to phases which remain residual. Quartz, plagioclase, K-feldspar and biotite (the most abundant phases in the $\mathrm{Pg}$ ) are the main reactants while garnet, kyanite 


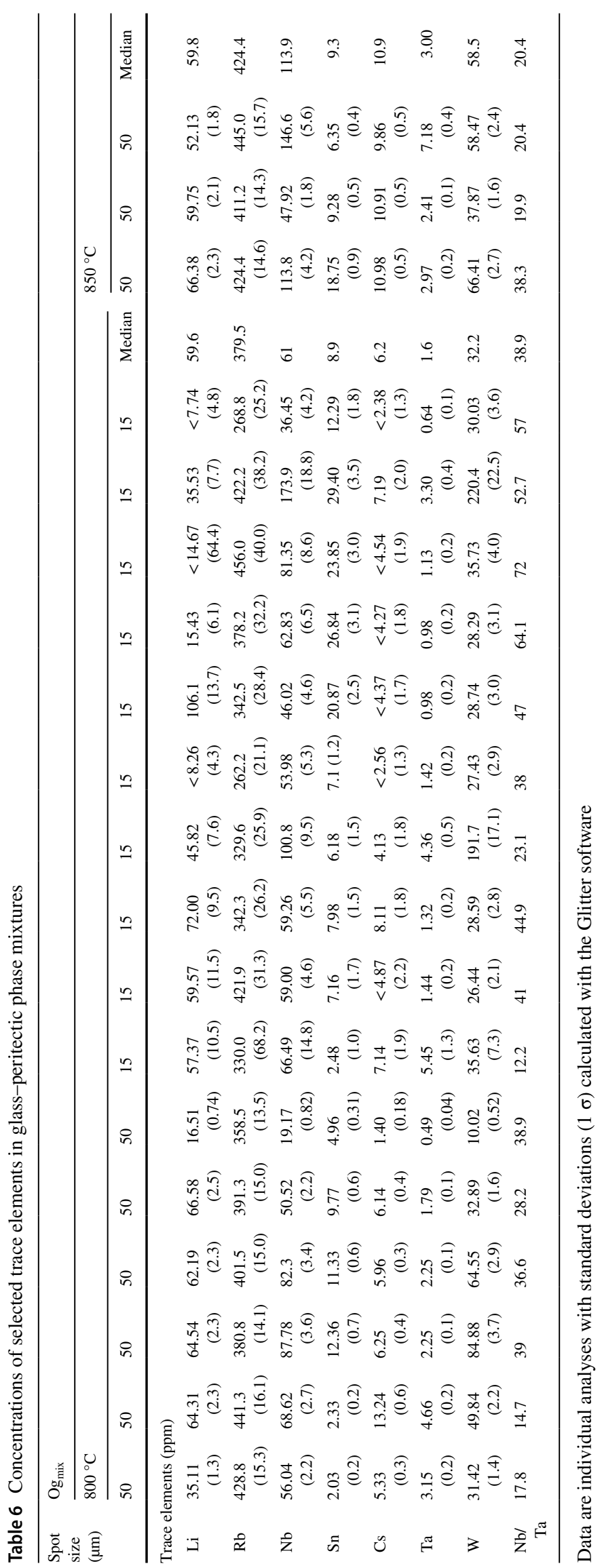


and muscovite are accessories. The melt product (composition in Table 4$)$ was mass-balanced $\left(\Sigma r^{2}=0.08\right.$, Table 7) by a linear combination of the four main reactants (compositions in Table A2), thus validating the stoichiometry of reaction (1). Quartz, plagioclase and K-feldspar are all involved as reactants in approximately equal amounts $(\sim 0.3 \mathrm{~g}$ per $1 \mathrm{~g}$ of formed melt) whereas biotite participates in a smaller proportion $(0.13 \mathrm{~g}$ per $1 \mathrm{~g}$ of formed melt, Table 7$)$, both features being characteristic of water-fluxed melting reactions (e.gHarris and Inger 1992; Johannes and Holtz 1996). Calculations with garnet and kyanite included as reactants did not change the results significantly and confirm their accessory role in (1). It should be noted that reaction (1) is congruent and must be accompanied by subordinate incongruent reactions (muscovite and biotite dehydration-melting, see below) to account for minor amounts of peritectic phases $\left(\mathrm{Spl}_{\mathrm{per}}\right.$ and $\left.\mathrm{Ilm}_{\mathrm{per}}\right)$.

At $850{ }^{\circ} \mathrm{C}$ in the $\mathrm{Pg}$, the melt distribution is similar to observed at $800{ }^{\circ} \mathrm{C}$. However, the degree of melting is more than twice higher $(\sim 18 \mathrm{vol} \%)$ than at $800^{\circ} \mathrm{C}(\sim 8 \%)$. The scarce muscovites initially present are entirely consumed as at $800{ }^{\circ} \mathrm{C}$. The peritectic assemblage changes from 800 (Brearley 1987) to $850{ }^{\circ} \mathrm{C}$ and, overall, the biotite dehydration-melting reaction is more advanced. Yet, residual biotite persists in significant amount indicating that the reaction is not overstepped. It can be written as:

$\mathrm{Bt}_{\mathrm{res}}+\mathrm{Qz}_{\mathrm{res}}+\mathrm{Pl}_{\mathrm{res}} \rightarrow \mathrm{Melt}+\mathrm{Opx}_{\mathrm{per}}+\mathrm{Spl}_{\mathrm{per}}+\mathrm{Kfs}_{\mathrm{per}}$,

where "res" is as above and "per" refers to a peritectic phase. Reaction (2) is closely analogous to the fluid-absent biotite dehydration-melting reaction previously studied in metagreywackes (Montel and Vielzeuf 1994, 1997) as well as in biotite gneiss and two-micas pelite (Rushmer 2001 and additional references therein). In (2), accessory reactants such as garnet, kyanite and muscovite have been omitted. Yet, garnet is locally involved as illustrated by the development of a $\mathrm{Grt}_{\text {per }}$ rim on a Grt ${ }_{\text {res }}$ near reacting biotite (Fig. 3f). The stoichiometry of reaction (2) was tested by mass-balancing the composition of reactants (Table A2) against the composition

Table 7 Stoichiometries of melting reactions determined by mass-balance

Reaction (1): fluid-present melting, $\operatorname{Pg} 800{ }^{\circ} \mathrm{C}$

\begin{tabular}{|c|c|c|c|c|c|c|c|c|c|}
\hline \multicolumn{4}{|c|}{ Reactants } & \multicolumn{5}{|c|}{ Products } & \multirow[t]{2}{*}{$\Sigma r^{2}$} \\
\hline $\begin{array}{l}\mathrm{Bt}_{\mathrm{res}} \\
(\mathrm{g})\end{array}$ & $\begin{array}{l}\mathrm{Qtz}_{\text {res }} \\
(\mathrm{g})\end{array}$ & $\begin{array}{l}\mathrm{Pl}_{\text {res }} \\
(\mathrm{g})\end{array}$ & $\begin{array}{l}\mathrm{Kfs}_{\text {res }} \\
(\mathrm{g})\end{array}$ & \multicolumn{5}{|l|}{$\begin{array}{l}\text { Melt } \\
\text { (g) }\end{array}$} & \\
\hline 0.13 & 0.29 & 0.31 & 0.31 & \multicolumn{5}{|l|}{1} & 0.08 \\
\hline \multicolumn{10}{|c|}{ Reaction (2): biotite dehydration-melting, $\operatorname{Pg} 850^{\circ} \mathrm{C}$} \\
\hline \multicolumn{4}{|c|}{ Reactants } & \multicolumn{5}{|c|}{ Products } & \multirow[t]{2}{*}{$\Sigma \mathrm{r}^{2}$} \\
\hline $\begin{array}{l}\mathrm{Bt}_{\text {res }} \\
(\mathrm{g})\end{array}$ & $\begin{array}{l}\mathrm{Qtz}_{\text {res }} \\
(\mathrm{g})\end{array}$ & $\begin{array}{l}\mathrm{Pl}_{\text {res }} \\
(\mathrm{g})\end{array}$ & $\begin{array}{l}\mathrm{Kfs}_{\text {res }} \\
(\mathrm{g})\end{array}$ & $\begin{array}{l}\text { Melt } \\
(\mathrm{g})\end{array}$ & $\begin{array}{l}\text { Opx } \\
(\mathrm{g})\end{array}$ & $\begin{array}{l}\mathrm{Spl}_{\text {per }} \\
(\mathrm{g})\end{array}$ & $\begin{array}{l}\operatorname{Ilm}_{\text {per }} \\
(\mathrm{g})\end{array}$ & $\begin{array}{l}\mathrm{Kfs}_{\text {per }} \\
(\mathrm{g})\end{array}$ & \\
\hline 1 & 0.20 & 0.71 & nd & 1.15 & 0.22 & 0.21 & nd & 0.07 & 0.11 \\
\hline
\end{tabular}

Reaction (3): muscovite dehydration-melting, $\mathrm{Og} 800{ }^{\circ} \mathrm{C}$

\begin{tabular}{|c|c|c|c|c|c|c|c|c|c|}
\hline \multicolumn{3}{|c|}{ Reactants } & \multicolumn{6}{|c|}{ Products } & \multirow[t]{2}{*}{$\Sigma \mathrm{r}^{2}$} \\
\hline $\begin{array}{l}\text { Ms } \\
(\mathrm{g})\end{array}$ & $\begin{array}{l}\mathrm{Qtz}_{\text {res }} \\
(\mathrm{g})\end{array}$ & $\begin{array}{l}\mathrm{Pl}_{\text {res }} \\
(\mathrm{g})\end{array}$ & $\begin{array}{l}\text { Melt } \\
(\mathrm{g})\end{array}$ & $\begin{array}{l}\mathrm{Bt}_{\text {per }} \\
(\mathrm{g})\end{array}$ & $\begin{array}{l}\mathrm{Spl}_{\mathrm{per}} \\
(\mathrm{g})\end{array}$ & $\begin{array}{l}\mathrm{Ilm}_{\text {per }} \\
(\mathrm{g})\end{array}$ & $\begin{array}{l}\mathrm{Als}_{\text {per }} \\
(\mathrm{g})\end{array}$ & $\begin{array}{l}\mathrm{Kfs}_{\text {per }} \\
(\mathrm{g})\end{array}$ & \\
\hline 1 & 0.30 & 0.43 & 1.12 & 0.01 & 0.03 & 0.00 & 0.24 & 0.28 & 0.15 \\
\hline
\end{tabular}

Reaction (3): muscovite dehydration-melting, $\mathrm{Og} 850{ }^{\circ} \mathrm{C}$

\begin{tabular}{|c|c|c|c|c|c|c|c|c|c|}
\hline \multicolumn{3}{|c|}{ Reactants } & \multicolumn{6}{|c|}{ Products } & \multirow[t]{2}{*}{$\Sigma \mathrm{r}^{2}$} \\
\hline $\begin{array}{l}\text { Ms } \\
\text { (g) }\end{array}$ & $\begin{array}{l}\mathrm{Qtz}_{\text {res }} \\
(\mathrm{g})\end{array}$ & $\begin{array}{l}\mathrm{Pl}_{\text {res }} \\
(\mathrm{g})\end{array}$ & $\begin{array}{l}\text { Melt } \\
(\mathrm{g})\end{array}$ & $\begin{array}{l}\mathrm{Bt}_{\text {per }} \\
(\mathrm{g})\end{array}$ & $\begin{array}{l}\mathrm{Spl}_{\mathrm{per}} \\
(\mathrm{g})\end{array}$ & $\begin{array}{l}\mathrm{Ilm}_{\text {per }} \\
(\mathrm{g})\end{array}$ & $\begin{array}{l}\text { Als }_{\text {per }} \\
(\mathrm{g})\end{array}$ & $\begin{array}{l}\mathrm{Kfs}_{\text {per }} \\
(\mathrm{g})\end{array}$ & \\
\hline 1 & 0.36 & 0.34 & 1.14 & 0.06 & 0.01 & 0.00 & 0.23 & 0.26 & 0.66 \\
\hline
\end{tabular}

Reaction (1) normalized to $1 \mathrm{~g}$ of melt; reactions (2) and (3) normalized to $1 \mathrm{~g}$ of biotite and muscovite, respectively

$B t$ biotite, $Q t z$ quartz, $P l$ plagioclase, $K f s$ alkali feldspar, $O p x$ orthopyroxene, $S p l$ hercynitic spinel, $I \mathrm{~lm}$ : ilmenite, $M s$ muscovite, $A l s$ sillimanitemullite mixture (estimated composition $20 \mathrm{wt} \% \mathrm{SiO}_{2}, 80 \mathrm{wt} \% \mathrm{Al}_{2} \mathrm{O}_{3}$ )

res refers to a residual and per to a peritectic phase (see text)

$n d$ phase not considered in the calculations 
of products (melt, Table 4; peritectic phases, Table A4) in the Pg $850{ }^{\circ} \mathrm{C}$ charge. The low $\Sigma r^{2}(0.11$, Table 7$)$ indicates mass conservation between the left- and right-hand sides of (2). A mass of $1.15 \mathrm{~g}$ of melt is produced for $1 \mathrm{~g}$ of reacted biotite (Table 7) or $\sim 1.5 \mathrm{~cm}^{3}$ of melt for $1 \mathrm{~cm}^{3}$ of biotite. This production rate is broadly consistent with the calculated degree of melting ( $\sim 18 \mathrm{vol} \%)$, of which $\sim 8 \mathrm{vol} \%$ should be accounted for by interstitial water since (2) occurs together with (1) and, so, the degree of melting is controlled by the sum of interstitial water and water released from biotite breakdown. For 10 (i.e., 18-8) vol\% melt to be generated with reaction (2), $\sim 7$ vol\% biotite (35\% of the initial fraction) must be consumed, consistent with the persistence of a large amount of residual biotite in the charge (Fig. 3d-f).

In the $\mathrm{Og} 800{ }^{\circ} \mathrm{C}$ charge, muscovite has totally reacted out and is replaced by the in situ crystallization of peritectic phases outlining contours of the pre-existing mica (Fig. 5a) and which include $\mathrm{Bt}_{\mathrm{per}}$ (more $\mathrm{Ti}-$ and $\mathrm{Mg}$ rich than the starting composition), $\mathrm{Spl}_{\text {per }}, \mathrm{Ilm}_{\mathrm{per}}, \mathrm{Sill}_{\mathrm{per}}, \mathrm{Mul}_{\mathrm{per}}$ and $\mathrm{Kfs}$ per (more Na- and less $\mathrm{K}$ rich than the starting composition). This indicates that, as observed in the equivalent Pg charge, the muscovite dehydration-melting reaction (e.g., Spear 1995 ) has been overstepped. Given the abundance of muscovite in the $\mathrm{Og}$ (13 wt\%), muscovite dehydration-melting is a major melting mechanism at $800{ }^{\circ} \mathrm{C}$. Melt pools and melt plus peritectic phase mixtures follow the heterogeneous initial distribution of muscovite in the starting microcore (Figs. 1, 4). Biotite is present both as a residual (incipient biotite breakdown results in the formation of small melt pools plus Spl $\mathrm{per}_{\text {and }} \mathrm{Ilm}_{\text {per }}$, e.g., Brearley 1987) and peritectic (Fig. 5b) and, so, the biotite dehydration-melting reaction has not been overstepped, as observed in the corresponding Pg charge. In mica-free zones, quartz and feldspars have melt present at grain boundaries. This could result from muscovite reaction zones being close to but out of the section plane or, alternatively, from interstitial water promoting melting in mica-free zones. However, large amount of interstitial water would induce global melting of the microcore, which is not observed. The muscovite dehydration-melting reaction in the $\mathrm{Og}$ at $800{ }^{\circ} \mathrm{C}$ can be written as:

$$
\begin{aligned}
& \mathrm{Ms}+\mathrm{Qz}_{\mathrm{res}}+\mathrm{Pl}_{\mathrm{res}} \\
& \rightarrow \text { Melt }+\mathrm{Bt}_{\mathrm{per}}+\mathrm{Spl}_{\mathrm{per}}+\mathrm{Ilm}_{\mathrm{per}}+\mathrm{Als}_{\mathrm{per}}+\mathrm{Kfs}_{\mathrm{per}},
\end{aligned}
$$

where the suffixes "res" and "per" have the same signifi-

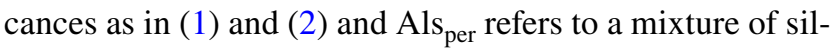
limanite and mullite. Accessory reactants such as $\mathrm{Bt}_{\text {res }}$ have been omitted in (3). Reaction (3) is analogous to the muscovite dehydration-melting reactions previously identified in quartzites and pelites (Brearley and Rubie 1990; Connolly et al. 1997; Patiño Douce and Harris 1998; Rushmer 2001). The stoichiometry of reaction (3) has been determined by mass-balancing the compositions of reactants (Table A2) and melt compositions (Table 4) plus peritectic phases (Table A5). The low $\Sigma r^{2}(0.15$, Table 7) indicates satisfactory mass-balance between the left- and right-hand sides of

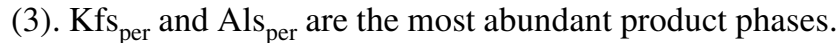
$\mathrm{Bt}_{\mathrm{per}}, \mathrm{Spl}_{\mathrm{per}}$ and $\mathrm{Ilm}_{\mathrm{per}}$ are all present in very small amounts $(<0.05 \mathrm{~g}$ per $1 \mathrm{~g}$ of reacted muscovite) consistent with the small concentrations of $\mathrm{Fe}, \mathrm{Mg}$ and $\mathrm{Ti}$ in muscovite. A mass of $1.12 \mathrm{~g}$ melt is produced for $1 \mathrm{~g}$ of reacted muscovite $(\sim 1.3$ $\mathrm{cm}^{3}$ melt for $1 \mathrm{~cm}^{3}$ muscovite, Table 7). Given that the $\mathrm{Og}$ contains $13 \mathrm{wt} \%$ (corresponding to $13 \mathrm{vol} \%$ ) muscovite, total consumption of muscovite following reaction (3) would produce 16 vol $\%$ melt, close to but higher than the $13 \mathrm{vol} \%$ melt determined from image analysis especially if additional sources of water (mainly interstitial water) are considered. The higher melt fraction in the Og than in the Pg charge at $800{ }^{\circ} \mathrm{C}$ (e.g., $\sim 13$ vs. $\sim 8$ vol\% from image analysis) reflects the higher proportion of muscovite having reacted out in the former than in the latter protolith.

At $850{ }^{\circ} \mathrm{C}$, muscovite dehydration-melting is the essential melting mechanism in the $\mathrm{Og}$, as at $800{ }^{\circ} \mathrm{C}$. Muscovite is totally consumed at the two temperatures and biotite is significantly more reacted at $850{ }^{\circ} \mathrm{C}$ than at $800^{\circ} \mathrm{C}$. The formation of peritectic orthopyroxene in addition to ilmenite and spinel (Fig. 5f) marks the same change in peritectic assemblage as already noted from 800 to $850{ }^{\circ} \mathrm{C}$ in Pg charges and suggests an increased role of biotite breakdown in melt production, despite a low modal abundance in the Og. However, compositions of melt (Table 4) and peritectic phases (Table 6) differ only marginally between the two Og charges and, as a consequence, the calculated stoichiometry of reaction (3) is little modified from 800 to $850{ }^{\circ} \mathrm{C}$ (Table 7). Yet, the quality of the mass-balance calculations is less good at $850{ }^{\circ} \mathrm{C}$ than at $800{ }^{\circ} \mathrm{C}\left(\Sigma r^{2}=0.66\right.$ and 0.15 respectively, Table 7). The melt production calculated for $1 \mathrm{~g}$ of reacted muscovite is only slightly higher at $850{ }^{\circ} \mathrm{C}(1.14 \mathrm{~g})$ than at $800{ }^{\circ} \mathrm{C}(1.12 \mathrm{~g}$, Table 7$)$, which corresponds to a degree of melting of $17 \mathrm{vol} \%$ vs. $20 \mathrm{vol} \%$ calculated from image analysis in the $850{ }^{\circ} \mathrm{C} \mathrm{Og}$ charge. In comparison, an increase of $7 \mathrm{vol} \%$ in melt fraction (precisely what is observed from image analysis from $13 \mathrm{vol} \%$ at $800^{\circ} \mathrm{C}$ to $20 \mathrm{vol} \%$ at $850{ }^{\circ} \mathrm{C}$ ) is expected from melt productivity models (Clemens and Vielzeuf 1987; Johannes and Holtz 1996) when temperature is increased from 800 to $850{ }^{\circ} \mathrm{C}$ at constant pressure and amount of water. Such an increase in the degree of melting is not captured by our mass-balance calculations. We conclude that, in the $\mathrm{Og}$ at $850{ }^{\circ} \mathrm{C}$, the melting reaction is mainly controlled by muscovite dehydration-melting with only minor contribution of biotite and possibly interstitial water to the water budget.

In summary, the two source rocks experienced closely similar melting reactions. Such similarities in melting relations were already stated for hydrous systems by Vielzeuf and Schmidt (2001). At $800{ }^{\circ} \mathrm{C}$, the same muscovite 
dehydration-melting reaction (3) takes place in both protoliths and biotite follows the same type of incipient breakdown. Muscovite dehydration-melting is the dominant meltproducing reaction in the $\mathrm{Og}$ but has a negligible importance in the $\mathrm{Pg}$ which is nearly muscovite free. At $850{ }^{\circ} \mathrm{C}$, biotite breakdown follows reaction (2) both in the Pg and the $\mathrm{Og}$. Biotite dehydration-melting dominates the melting process in the $\mathrm{Pg}$, and, in the $\mathrm{Og}$, minor additional water is supplied. Last, interstitial water contributes to the global melting process following reaction (1), under conditions inappropriate for mica dehydration-melting $\left(\mathrm{Pg}\right.$ at $\left.800{ }^{\circ} \mathrm{C}\right)$ and in combination with the dehydration-melting reactions at 800 and $850{ }^{\circ} \mathrm{C}$. We conclude that both (i) the nature (and the composition) of micas and (ii) the temperature govern melt generation by dehydration-melting. Additional factors such as the presence of interstitial water, the modal abundance of micas and their repartitions in source rocks determine the total melt production and its distribution.

\section{Major element compositions of experimental melts}

Major element compositions of melts in this study are tightly grouped (Fig. 6; Table 4) being silica rich, peraluminous and leucocratic, resembling melt compositions from other melting experiments of natural two-mica protoliths generated over a wide range of experimental pressures, temperatures and melt fractions (Patiño Douce and Harris 1998; Rushmer, 2001). Melt compositions were found not to largely vary with the source rock (Patiño Douce and Harris 1998) which is consistent with results from this study as melts from $\mathrm{Pg}$ and Og charges differ only marginally (Fig. 6; Table 4). In addition, the $\mathrm{Pg}$ and the $\mathrm{Og}$ are significantly different (see for example bulk compositions and mica modal abundances), yet $\mathrm{Og}$ - and Pg-derived melts have the same major element characteristics than melts generated in other studies (Patiño Douce and Harris 1998; Rushmer 2001).

Melt production in this and previous experimental melting studies is governed by several reactions such as (1)-(3) detailed above (see also Brearley and Rubie 1990; Connolly et al. 1997; Patiño Douce and Harris 1998; Rushmer 2001). Though, the major element compositions of the formed melts are not strongly dependent on the dominant melting reaction. For example, the congruent water-fluxed melting reaction (1) produces a $\mathrm{SiO}_{2}$-rich, strongly peraluminous and felsic melt $\left(800{ }^{\circ} \mathrm{C} \mathrm{Pg}\right.$ charge), not significantly different (only slightly more $\mathrm{Al}_{2} \mathrm{O}_{3}$ rich and $\mathrm{FeO}_{\mathrm{t}}$ poor) than the one generated by the biotite dehydration-melting reaction (2) at $850{ }^{\circ} \mathrm{C}$ (Table 4; Fig. 6). Melts derived from the muscovite and biotite dehydration-melting reactions (respectively (3) and (2)) differ only marginally. The Og melts are slightly less mafic (i.e., lower $\mathrm{B}^{*}$ ) and less strongly peraluminous than Pg melts although both are leucocratic (Table 4; Fig. 6). Last, there is no clear indication from the 800 and $850{ }^{\circ} \mathrm{C} \mathrm{Og}$ experiments for a significant influence of the melt fraction (from 13 to 20 vol\% range according to image analysis) on melt composition. Therefore, major element melt compositions in our experiments are buffered.

One possible explanation is that kinetic factors are important enough to mask the role of melting reactions. Indeed, attainment of equilibrium is an issue in melting experiments of natural polymineralic assemblages at relatively low temperatures, whether single crystals, cores or powders are used (Brearley and Rubie 1990; Patiño Douce and Harris 1998; Hammouda and Pichavant 1999; Rushmer 2001). However, melts analyzed in different parts of the same charge (for example in muscovite reaction zones and in mica-free areas of $\mathrm{Og}$ charges) do not show systematic differences. Major element heterogeneities in melts are minor (see above) but their persistence is consistent with melting being kinetically controlled by dissolution of reactant phases and diffusive mass transport within the melt (Hammouda and Pichavant 1999, 2000; Devineau et al. 2005). However, their small magnitude indicates that close-to-equilibrium major element compositions have been reached. This is consistent with the observation that micas at 800 and $850{ }^{\circ} \mathrm{C}$ react as expected from equilibrium model reactions (Spear 1995; Holyoke and Rushmer 2002). The reactivity of reactant phases is demonstrated by the compositions of peritectic biotite and K-feldspar which markedly differ from their respective starting compositions and evolve consistently with protolith chemistries (same for peritectic orthopyroxene). Last, the convergence of melt compositions across studies and protoliths (see above) and the uniformity of melt major element chemistries over a large range of pressures, temperatures and melt fractions (Patiño Douce and Harris 1998) are unlikely to be controlled by kinetic factors only because differences in experimental methods and run durations should show up. Therefore, we conclude that near equilibrium major element distributions were attained in our experiments.

As previously emphasized, the same melting reactions take place in both protoliths; water-fluxed and mica dehydration-melting reactions occur simultaneously in the same charge. We note that the mica dehydration-melting reactions (2) and (3) both have spinel, ilmenite and alkali feldspar as products implying that the melts formed are saturated with identical peritectic assemblages, $\mathrm{Al}$ silicates and orthopyroxene being excepted. This explains the convergence of melt compositions produced with the two reactions although, in detail, major element compositions of peritectic phases slightly differ between $\mathrm{Og}$ and $\mathrm{Pg}$ and so melt compositions are not identical. The lack of peritectic Al silicates in reaction (2) is made up for by the presence of accessory kyanite in Pg which imparts a strong peraluminous character to the produced melt, a mechanism which also applies to reaction (1). The appearance of orthopyroxene at $850^{\circ} \mathrm{C}$ is not associated with a systematic change in melt chemistry. It has 
less impact on melt $\mathrm{FeO}_{t}$ and $\mathrm{FeO}_{t} / \mathrm{MgO}$ than the nature of the protolith ( $\mathrm{Pg}$ are more $\mathrm{FeO}_{t}$ rich than $\mathrm{Og}$ melts, Fig. 6). In the Og charge, orthopyroxene is present in negligible amounts. In the Pg charge, orthopyroxene is more abundant but other peritectic ferromagnesian phases (spinel, ilmenite) and residual biotite are also present and, so, the influence of orthopyroxene on melt composition is diluted. We speculate that the role of orthopyroxene would become more important at temperatures above $850{ }^{\circ} \mathrm{C}$ allowing biotite to be more extensively reacted and concentrations of ferromagnesian components to increase in the melt. To conclude, the major element characteristics and convergence of melt compositions generated from the two protoliths are best explained by the combined influence of the main melting reactions, i.e., reactions (1)-(3) act together to produce melts with a narrow range of major element compositions.

\section{Trace element compositions of experimental melts}

In contrast with the nearly homogeneous glass major element data, our melt trace element data show significant chemical variability, both at 800 and $850^{\circ} \mathrm{C}$. Assuming that analytical biases can be excluded, since contaminated glass spots have been filtered out, we explore below the possibility that the observed variability originates from heterogeneities in our starting materials. One possible type of heterogeneity is chemical, due to the variability of trace element concentrations in major phases of the protolith, mainly micas. Indeed, Rb (558-1034 ppm), Nb (87-228 ppm), Ta (3-10 ppm) and $\mathrm{W}(5-51 \mathrm{ppm})$ significantly vary in the $\mathrm{Og}$ biotite (Table 3). However, muscovite in Og, is less heterogeneous (74-88 ppm Li, 565-683 ppm Rb, 77-82 ppm $\mathrm{Nb}, 2-3$ ppm Ta, 69-103 ppm W; Table 3). Chemical variability in melts (calculated as standard deviation/mean of analyses) reach $26 \%$ for $\mathrm{Nb}$ and $86 \%$ for Ta in the $800{ }^{\circ} \mathrm{C}$ charge (Table 5). These variations appear very elevated since $\mathrm{Nb}$ and $\mathrm{Ta}$ are nearly homogeneously distributed in muscovite (only $3 \%$ and $11 \%$ dispersions). Chemical dispersions for $\mathrm{Li}$ and $\mathrm{Rb}$ in melts (respectively, 18\% and 13\%) are also higher than the compositional variability in the starting muscovite (dispersions of $\sim 9 \%$ and $\sim 10 \%$ ). Last, the dispersions for $\mathrm{W}$ in melts $\left(\sim 28 \%\right.$ and $\sim 22 \%$ at $800{ }^{\circ} \mathrm{C}$ and $\left.850{ }^{\circ} \mathrm{C}\right)$ match the one in muscovite $(\sim 23 \%)$ but overall mica chemical heterogeneity seems unable to explain the glass variability for all trace elements.

A second type of heterogeneity in the natural protoliths is textural. In Og microcores, micas are segregated in few layers (Fig. 1). Melt pools are preferentially associated with muscovite reaction zones pre-localized in micaceous layers although mica-free zones also contain melt (see above). Melt films extend to lengths $\geq \sim 1 \mathrm{~mm}$ and melt pools coexist at distances $>\sim 1 \mathrm{~mm}$ from each other (Fig. 4). Since, according to major elements (see above), melting is kinetically controlled by dissolution of reactants and diffusive mass transport in the melt, chemical homogenisation of trace elements should take place diffusively. Diffusion distances in the melt $(x)$ have been calculated for the different trace elements at 800 and $850{ }^{\circ} \mathrm{C}$ for a duration $(t)$ of 14 days using the tracer diffusion $(D)$ database of Zhang et al. (2010). Results $\left(x=(\mathrm{Dt})^{0.5}\right)$ stress the large differences existing between trace elements. For $\mathrm{Nb}, \mathrm{Ta}, \mathrm{Sn}$ and $\mathrm{W}$, very short diffusion distances were obtained, limited to $50 \mu \mathrm{m}$ maximum (calculations performed with both dry and wet rhyolitic melt $D$ ). Maximum diffusion distances for Cs are $100 \mu \mathrm{m}$ (calculations with dry and wet $D$ ) and they increase to $>2 \mathrm{~mm}$ for $\mathrm{Rb}$ (dry and wet $D$ ) and $>10 \mathrm{~mm}$ for Li (dry $D)$. These results are broadly consistent with chemical dispersions in glasses being the lowest for $\mathrm{Rb}(\sim 13$ and $~ 10 \%)$ and $\mathrm{Li}(18$ and $22 \%)$ and the highest for $\mathrm{Ta}(\sim 86 \%$ and $41 \%)$ at 800 and $850{ }^{\circ} \mathrm{C}$, while $\mathrm{Nb}(\sim 26 \%$ and $\sim 25 \%)$, Cs $(\sim 53 \%$ and $\sim 24 \%)$ and $\mathrm{W}(\sim 28 \%$ and $\sim 22 \%$, data in Table 5$)$ are intermediate. Taken globally, these calculations support the possibility of incomplete diffusive homogenization between rare element-enriched and -depleted zones of melt films (respectively, near and away from reacted muscovites). However, for $\mathrm{Li}$, the large diffusion distances calculated (in the same range as microcore sizes) are inconsistent with the observed dispersions and suggest that Li diffusive homogenization is perturbed by other processes, possibly $\mathrm{Li}$ incorporation in residual phases. We conclude that the trace element variability observed in experimental glasses is the consequence of combined chemical, mineralogical and textural heterogeneities inherited from the starting materials.

Sn is very low $(<20 \mathrm{ppm})$ in all analyzed glasses and also in most glass-peritectic phase mixtures despite high concentrations in one protolith ( 220 ppm Sn in the Og, Table 1). This uniform Sn depletion contrasts with the behavior of other elements, in particular $\mathrm{Nb}$, Ta and $\mathrm{W}$ and is attributed to Sn loss by alloying with the Au capsule, an experimental difficulty particularly severe under reducing conditions as in this study (e.g., Linnen et al. 1995).

\section{Behavior of rare elements during partial melting}

Several models have been proposed to describe the behavior of trace element during partial melting (e.g., Shaw 1970; Hanson 1978; Harris and Inger 1992). Concentrations in melt relative to source rock can be calculated for variable $\mathrm{F}$ with a relatively small number of input parameters (source rock concentrations, mineral/melt partition coefficients). In most models, the restite remains mineralogically the same from the onset of melting until melt extraction, see Hertogen and Gijbels (1976) for an exception. In contrast, complex mineralogical changes take place in our experiments such as (i) disappearance of reactant phases (muscovite), (ii) appearance of peritectic 
phases and (iii) changes in peritectic assemblage with varying temperature and melt fraction. These complexities have been circumvented by observing that the concentration of a given trace element relative to the source depends only on the bulk restite/melt partition coefficient $(D)$ and $F$ at the time of melt extraction (e.g., Hanson, 1978; Harris and Inger, 1992). This stresses the importance of $D$ which determines whether a trace element is preferentially concentrated in the melt or sequestered in restite phases. Rare element enrichment in crustal melts requires $D<1$.

$D$ cannot be determined rigorously from our experiments because two types of information are lacking. First, peritectic phases have not been analyzed individually for trace elements although data on glass-peritectic phase mixtures are available. Second, the restite assemblage includes residual reactant phases (see "Introduction") which should equilibrate with the formed melt but have not been characterized in experimental charges. We also assume that concentrations of trace elements in the melt are lower than the solubility of minerals with trace elements as ESCs (i.e., of cassiterite for Sn, see Linnen and Cuney 2005 for a summary of melt concentrations implied) so that no trace element mineral is part of the restite assemblage. Yet, two methods are presented below to constrain D for the rare elements of this study. Both are general in their principle but the $\mathrm{Og} 800{ }^{\circ} \mathrm{C}$ charge is selected for demonstration because (i) only a few trace element data are available for $\mathrm{Pg}$ charges, (ii) the $800{ }^{\circ} \mathrm{C} \mathrm{Og}$ charge has the largest number of analyses of glass-peritectic phase mixtures and (iii) biotite is not significantly involved in melt production (at the difference of at $850{ }^{\circ} \mathrm{C}$ ) and so muscovite dehydration-melting is the only reaction controlling the trace element distribution. In method 1 , the restite is reduced to the peritectic assemblage (thus, $D \sim C_{\text {per }} / C_{\text {melt }}$ where $C_{\text {per }}$ is the trace element concentration in the bulk peritectic assemblage). This assumes that residual phases do not equilibrate with the melt, which is reasonable given the short experimental durations and the slow element diffusivities in minerals. The peritectic assemblage is taken globally despite being in fact multiphase, i.e., including $\mathrm{Bt}_{\text {per }}, \mathrm{Spl}_{\text {per }}, \mathrm{Ilm}_{\text {per }}, \mathrm{Als}_{\text {per }}$ and $\mathrm{Kfs}_{\text {per }}$ in reaction (3). For each trace element, $C_{\text {per }}$ is calculated by subtracting the melt contribution from analyses of melt-peritectic phase mixtures, following the mass-balance equation:

$C_{\text {mix }}=C_{\text {melt }} \cdot M_{\text {melt }}+C_{\text {per }} \cdot\left(1-M_{\text {melt }}\right)$,

where $C_{\text {mix }}$ and $C_{\text {melt }}$ are as defined above and $M_{\text {melt }}$ is the mass fraction of melt in the analyzed mixture. This latter is estimated from surfacic proportions of melt and peritectic phases determined on SEM images of mixtures zones taken prior and after LA-ICP-MS analysis (Fig. A3), using image processing methods (see above and Table A7). For each element, $C_{\text {per }}$ is calculated from the different $C_{\text {mix }}$ analyses and the different local $M_{\text {melt }}, C_{\text {melt }}$ being constant and equal to the median concentration in the $800{ }^{\circ} \mathrm{C}$ charge (Table 5). Results are detailed in Table A7. To more fully document the dispersion, $D\left(=C_{\mathrm{per}} / C_{\mathrm{melt}}\right)$ are calculated from all $C_{\mathrm{per}}$ and $C_{\text {melt }}$ analyzed in the $\mathrm{Og} 800{ }^{\circ} \mathrm{C}$ charge and the results are summarized in Table A8.

In method 2, a mass-balance approach anchored in the melting reaction (3) is implemented. Masses of trace elements released by the melting reaction are calculated and then distributed at equilibrium between the melt and the restite assemblage. For a given trace element, the mass released to the melt is equal to the sum of concentrations in reactants (Table 3; A3) each weighted proportionally to the stoichiometry of the melting reaction (Table 7). As a first step, the restite is reduced to the peritectic assemblage to allow comparison with method 1 . However, the multiphase nature of the peritectic assemblage is fully recognized and the trace element concentration of each peritectic phase $\left(c_{\text {per }}\right)$ is calculated from $C_{\text {melt }} . K_{\mathrm{d}}$, where $K_{\mathrm{d}}$ is the partition coefficient for the phase concerned. The calculations are performed element by element and iteratively. An initial trace element concentration is allocated to the melt and $c_{\text {per }}$ calculated for all peritectic phases. The calculations are repeated with different $C_{\text {melt }}$ until the mass of the trace element in melt and peritectic phases equals the mass released by the reaction. From this mass-balanced set of $C_{\text {melt }}$ and $c_{\text {per, }}, C_{\text {per }}$ is calculated from the sum of $c_{\text {per }}$ times mass for all peritectic phases in the assemblage. Finally, $D$ is calculated from $C_{\text {per }} / C_{\text {melt }}$, where $C_{\text {melt }}$ is the measured concentration (Table A9). Method 2 requires $K_{\mathrm{d}}$ for all trace elements in all phases of the peritectic assemblage. In this study, a set of partition coefficients derived from the Macusani Volcanics has been used (Table A9). Biotite/ liquid $K_{\mathrm{d}}$ for $\mathrm{Li}, \mathrm{Rb}, \mathrm{Nb}, \mathrm{Cs}, \mathrm{Ta}$ (respectively, 3.40, 2.74, 9.69, 0.44, 2.07, Table A9) compare well with the results $(1.7,1.9,4.85-9.210 .3,2.64-3.93)$ of Icenhower and London (1995) and Stepanov and Hermann (2013). $K$-feldspar/ liquid $K_{\mathrm{d}}$ for $\mathrm{Li}, \mathrm{Rb}$ and $\mathrm{Cs}$ (respectively, 0.12, 0.95 and 0.026, Table A9) are within literature ranges (0.05-0.22, 0.68-1.03 and 0.03-0.13, Icenhower and London 1996; Acosta-Vigil et al. 2010; Hulsbosch et al. 2014; Villaros and Pichavant 2019). For Al silicate ( $\left.\mathrm{Als}_{\mathrm{per}}\right)$, the $K_{\mathrm{d}}$ (andalusite/melt data) are all in the 0.01 to 0.001 range (Table A9). Hercynitic spinel $\left(\mathrm{Spl}_{\text {per }}\right)$, the only phase for which the $K_{\mathrm{d}}$ were estimated (Table A9), is assumed to be the W-bearing phase required by the $C_{\text {mix }}$ data (see above).

$C_{\text {per }}$ and $D$ calculated with both methods are plotted in Figs. 8 and 9, respectively. The dispersion in $C_{\text {per }}$ with method 1 is the result of several factors including differences in peritectic modal compositions (see above, Fig. A3 and Table A7), mineralogical variations in the third 
direction (calculations of $M_{\text {melt }}$ only use 2D images) and spatial variability in $C_{\text {melt }}$. As a consequence, D calculated with method 1 are dispersed and, for some elements, significantly different $\mathrm{D}$ are obtained with method 1 when compared to method 2 (Fig. 9). However, the important point is that the two methods yield consistent partitioning trends for all elements.

$L i, C s$. These two elements show a similar behavior. Both the $C_{\text {mix }}$ data (see above) and the $C_{\text {per }}$ and D calculations consistently demonstrate strong preferential partitioning toward the melt. $\mathrm{Bt}_{\mathrm{per}}$ is the only major host for $\mathrm{Li}$ $\left(K_{\mathrm{d} \mathrm{Li}}>1\right.$, Table A9) and for Cs in the peritectic assemblage, being only present in small proportions (Table 7). Therefore, for both elements, $D$ stays $<1$ (Fig. 9). However, $D_{\mathrm{Li}}$ higher than in this study are expected for protoliths and muscovite dehydration-melting reactions leading to higher $\mathrm{Bt}_{\mathrm{per}}$ proportions than found in the Og peritectic assemblages. Therefore, for melts generated by muscovite dehydration-melting, Li concentrations are inversely correlated with proportions of biotite in the peritectic assemblage. In cases where the melt has time to equilibrate with residual Li-bearing phases such as biotite before being extracted, an increase in $\mathrm{D}_{\mathrm{Li}}$ relative to values in this study is also anticipated, which would reduce the melt $\mathrm{Li}$ content.

$R b$. Both the $C_{\text {mix }}$ data and the $C_{\text {per }}$ calculations show that $\mathrm{Rb}$ is not very much fractionated between melt and peritectic assemblage. $D_{\mathrm{Rb}}$ is lower than 1 (Fig. 9) with the two calculation methods indicating preference for the melt. With $K_{\mathrm{d} \mathrm{Rb}}$ for $\mathrm{Kfs}_{\text {per }}$ slightly $<1$ and $K_{\mathrm{d} \text { Rb }}$ for other peritectic phases $<<1, \mathrm{Bt}_{\text {per }}\left(K_{\mathrm{d} \mathrm{Rb}}>2.5\right.$, Table A9) is again not abundant enough in the $800{ }^{\circ} \mathrm{C} \mathrm{Og}$ charge to increase $C_{\text {per }}$ and so $D_{\mathrm{Rb}}$ is pulled to values $<1$. Elimination of K-feldspar from the peritectic assemblage (for example, if melting takes place under fluid present, Harris and Inger 1992) would further decrease $\mathrm{D}_{\mathrm{Rb}}$ and increase the $\mathrm{Rb}$ concentration of the melt. However, melt fractions generally differ between fluid present and fluid absent. The stronger Rb enrichment in melt found under fluid absent (Harris and Inger 1992) is most probably the result of $F$ being much smaller in the former $(0.11)$ than in the latter case $(0.41)$ since $D_{\mathrm{Rb}}$ should be higher. This illustrates the interplay between the two variables, $F$ and $D$, in the control of trace element enrichment.

$N b, T a$. For these two elements, consistent $D$ values are obtained with the two methods, confirming the $C_{\text {mix }}$ data and indicating preferential partitioning toward the peritectic assemblage. The measured and calculated $C_{\text {melt }}$ are also very close to each other (Table A9) but we point out that the calculated $C_{\text {melt }}$ sensitively depend on $K_{\mathrm{d} \mathrm{Nb}}$ and $K_{\mathrm{d} \mathrm{Ta}}$ for Spl $\mathrm{Ser}_{\text {pr }}$ Fluid-absent dehydration-melting of muscovite results in $\mathrm{Nb}$ and Ta mainly sequestered in peritectic phases. However, our data do not allow to conclude on melt/peritectic $\mathrm{Nb} / \mathrm{Ta}$ partitioning, a consequence of the dispersion in $C_{\text {melt }}$ and $C_{\text {per }}$.
The median $\mathrm{Nb} / \mathrm{Ta}$ (higher in $C_{\text {per }}$ than in $C_{\text {melt }}$, Tables 5, $\mathrm{A} 7$, A9; Fig. 10b) suggest that $\mathrm{Nb}$ is slightly more preferentially partitioned than Ta in the peritectic assemblage but the $C_{\text {mix }}$ data (see above) and $D$ calculations (Tables A8; A9) imply the opposite. In any case, the melt/peritectic $\mathrm{Nb} / \mathrm{Ta}$ fractionation is small (Stepanov and Hermann 2013; Stepanov et al. 2014). Melts produced by dehydration-melting of muscovite in Og charges have $\mathrm{Nb} / \mathrm{Ta}$ (medians 27-29, Table 5) significantly higher than the $\mathrm{Og}$ source rock $(\mathrm{Nb} / \mathrm{Ta}=12$, Table 1) and mainly reflect the composition of the starting muscovite $(\mathrm{Nb} / \mathrm{Ta} \sim 32-39$, Fig. 10b). Despite the presence of $\mathrm{Bt}_{\text {per }}\left(\mathrm{Nb} / \mathrm{Ta} \sim 140\right.$ from Table A9) in the $800{ }^{\circ} \mathrm{C}$ charge, the melt $\mathrm{Nb} / \mathrm{Ta}$ is not pulled to values much lower than muscovite because the proportion of $\mathrm{Bt}_{\mathrm{per}}$ is small and counterbalanced by other low $\mathrm{Nb} / \mathrm{Ta}$ peritectic phases. However, as emphasized above for $\mathrm{Li}$, a $\mathrm{Bt}_{\text {per }}$ proportion higher than observed in this study would presumably lead to a Nb/ Ta restite-melt fractionation (Stepanov and Hermann 2013) stronger than observed in $\mathrm{Og}$ charges. $\mathrm{Nb}$ and $\mathrm{Ta}$, thus, provide further illustration of the importance of peritectic phase assemblages and proportions for element partitioning during crustal melting.

$W$. From the $C_{\text {mix }}$ data, this element is commonly but not systematically enriched in glass-peritectic phase mixtures (see above) and the $\mathrm{D}_{\mathrm{W}}$ results are dispersed. With method $1, D_{W}$ ranges from 0.64 to 3 (median slightly $<1$, Table A8). With method 2, $D_{W}(2.70)$ is in the upper range of results with method 1 (Table A9; Fig. 9). Although caution is needed with method 2 which sensitively depends on $K_{\mathrm{d} \text { W }}$ for $\mathrm{Spl}_{\text {per, }}$, calculated and measured $C_{\text {melt }}$ are in close agreement from each other (Table A9). In other words, changing $K_{\mathrm{d} \text { W }}$ for $\mathrm{Spl}_{\text {per }}$ would lead to calculated $C_{\text {melt }}$ differing from measured. It is also reminded that, at $850^{\circ} \mathrm{C}$, the $C_{\text {mix }}$ data consistently indicate $W$ enrichment in mixtures (see above). Therefore, the high $D_{W}$ results (upper part of the range with method 1 and method 2) are preferred and values $<1$ with method 1 are interpreted to represent $\mathrm{Spl}_{\text {per }}$-poor peritectic mixtures. This implies that $\mathrm{W}$ is partitioned in the peritectic assemblage rather than in the melt. We note that $K_{\mathrm{d} \text { W }}$ for biotite is $<1$ (Table A9) unlike other elements $(\mathrm{Li}, \mathrm{Rb}, \mathrm{Nb}$, Ta) and so large changes in $D_{w}$ are not expected in case of $\mathrm{Bt}_{\text {per }}$-rich peritectic assemblages. This implies that biotite is not a key $\mathrm{W}$ sequestering phase in high grade residual source rocks. In contrast, the elevated $K_{\mathrm{d}}$ w for muscovite ( 2, Raimbault and Burnol 1998; Michaud and Pichavant 2020) makes this phase critical in the supply of $W$ to crustal melts.

$S n$. Because of Sn loss to the capsule and underestimation of $C_{\text {melt }}$ and $C_{\text {mix }}$, method 1 cannot be implemented. Results with method 2 (calculated $C_{\text {melt }}=50.8 \mathrm{ppm}, \mathrm{D}=0.36$, Table A9) depend directly on $K_{\mathrm{d} \mathrm{Sn}}$ for $\mathrm{Spl}_{\text {per }}$ which cannot be constrained from $C_{\text {melt }}$ (as done for W) and so the partitioning behavior of $\mathrm{Sn}$ remains unconstrained. 
Fig. 8 Trace element concentrations in peritectic assemblages $\left(C_{\text {per }}\right)$ calculated for the $\mathrm{Og}$ charge at $800{ }^{\circ} \mathrm{C}$. Results with the methods of calculation detailed in text are compared (method 1: black diamonds; method 2: cross). For method 1 , the small symbols represent individual calculations and the large symbol the median value (Table A7). Results with method 2 are detailed in Table A9. Median trace element concentrations in melt $\left(C_{\text {melt }}\right.$, Table 5) are shown for comparison
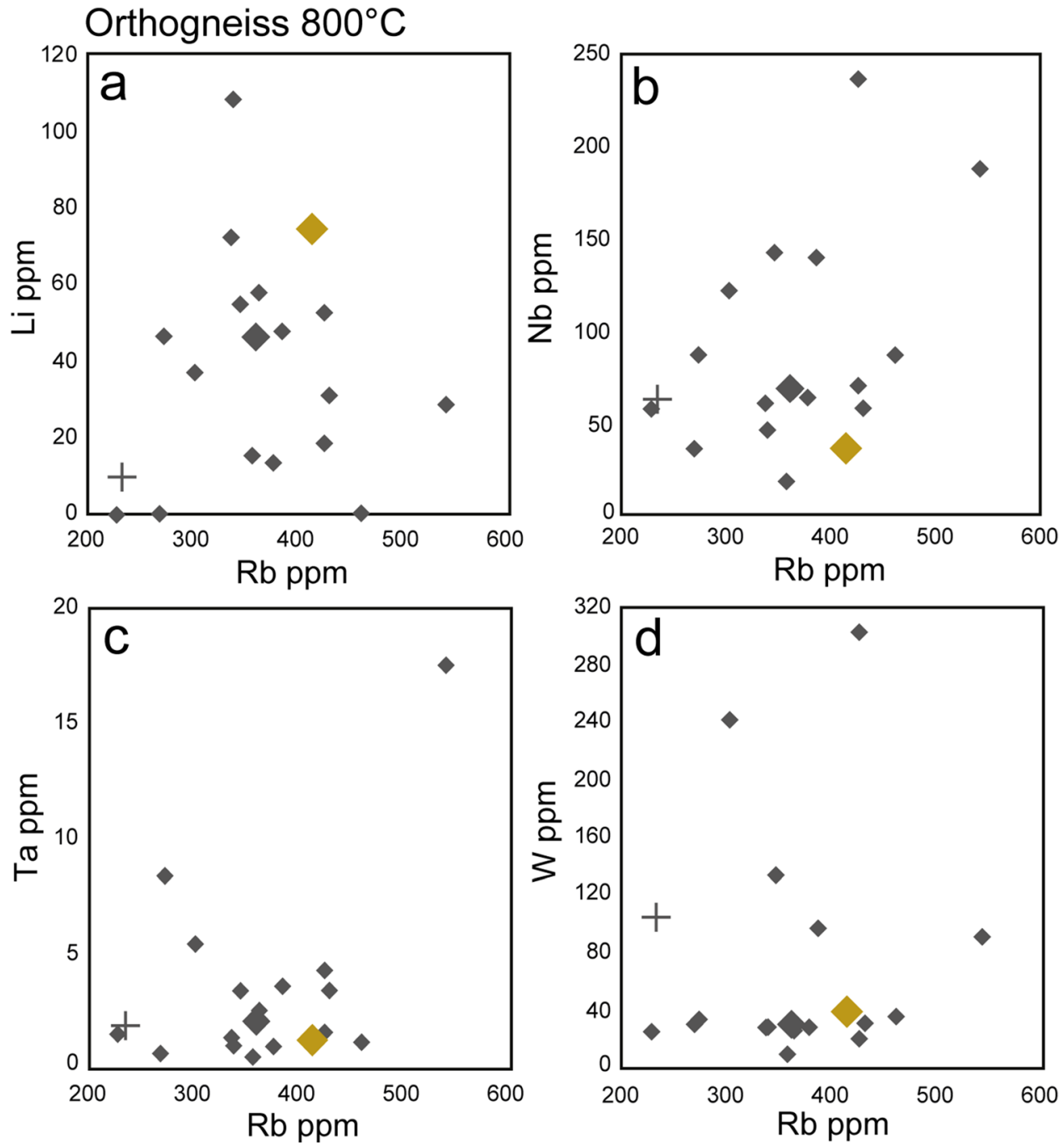

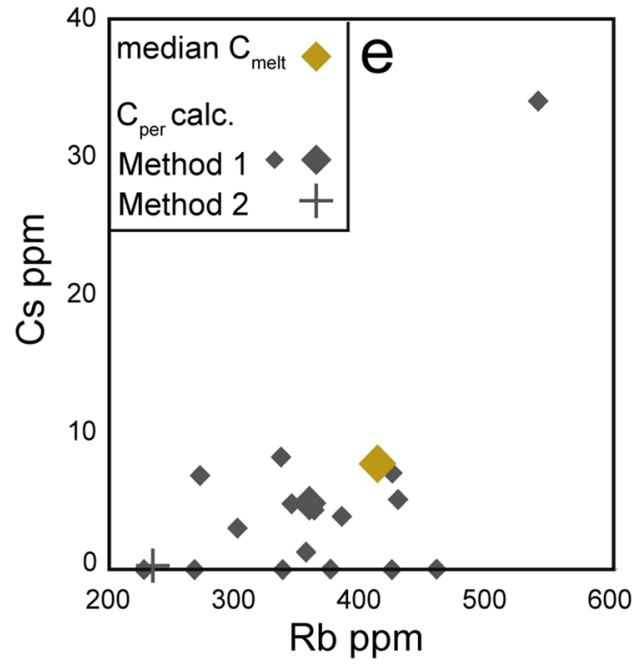

Rare element distributions during biotite dehydrationmelting are not as well constrained as during muscovite dehydration-melting. However, method 2 was tentatively applied to the $850^{\circ} \mathrm{C} \mathrm{Pg}$ and reaction (2) assuming $K_{\mathrm{dLi}}$ and
$K_{\mathrm{d} \text { Cs }}$ for orthopyroxene $=0$. It yields a calculated $C_{\text {melt }}$ of $164 \mathrm{ppm}$ for Li (vs. $183 \mathrm{ppm}$, Table 5) and of $27 \mathrm{ppm}$ for Cs (vs. 19 ppm, Table 5), consistent with biotite (163-219 ppm $\mathrm{Li}, 29-31 \mathrm{ppm}$ Cs, Table 3) being the main reactant in (2). 


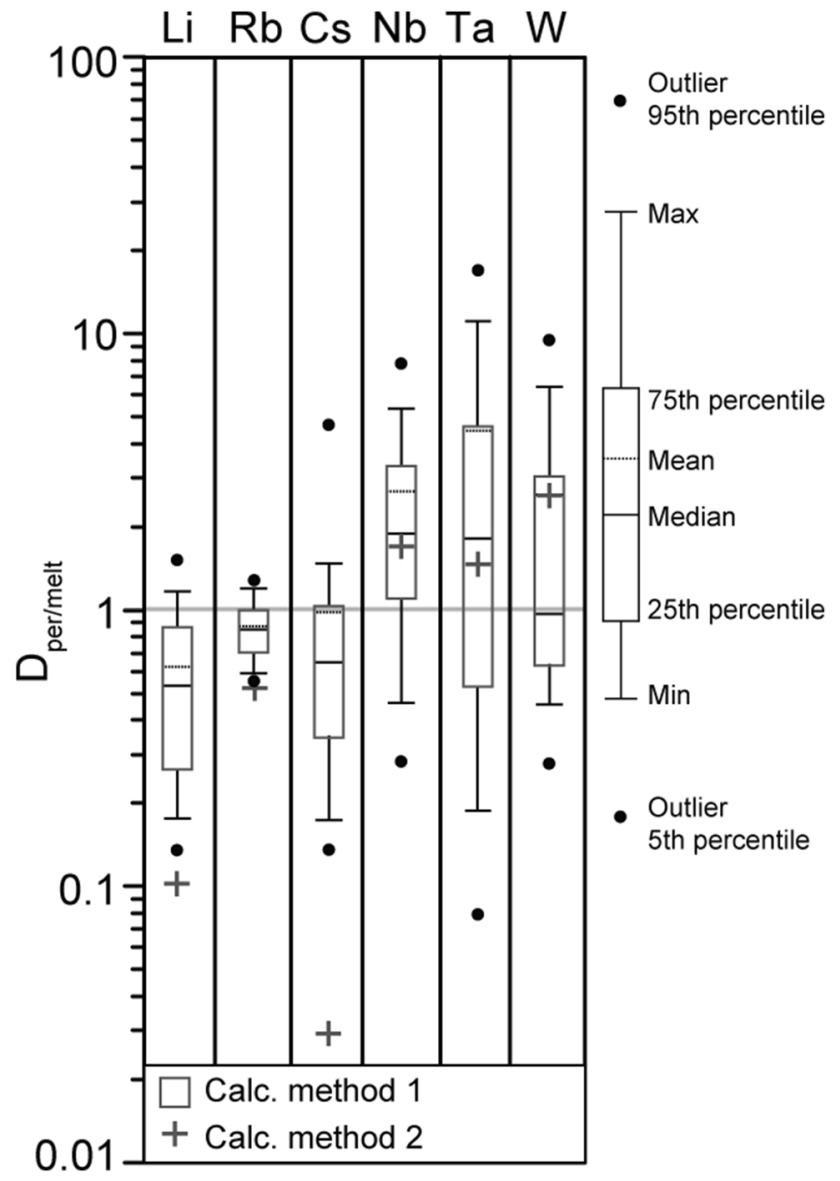

Fig. 9 Bulk trace element partition coefficients (D) between melt and peritectic assemblages for $\mathrm{Li}, \mathrm{Rb}, \mathrm{Cs}, \mathrm{Nb}, \mathrm{Ta}, \mathrm{W}$. Results using method 1 are shown as boxplots (Table A8) and using method 2 as crosses (Table A9). $D$ values $>1$ indicate preferential partitioning toward the peritectic assemblage and $\mathrm{D}<1$ toward the melt. See text for additional details

Therefore, Li concentrations in melts generated by biotite dehydration-melting are positively correlated with proportions of reactant biotite and its $\mathrm{Li}$ concentrations. Both the calculated $D_{\mathrm{Li}}$ and $D_{\mathrm{Cs}}$ are very low $(<0.1)$, consistent with the inferred absence of Li- and Cs-bearing phase in the peritectic assemblage. However, as noted for muscovite dehydration-melting, chemical equilibration of the melt with residual biotite (if present) would increase the $D$ values.

\section{Implications for natural rare element-rich melts}

\section{Comparison between experimental melts and Variscan granites}

Major element chemistries of experimental melts are compared with whole-rock compositions of Variscan granites and volcanic equivalents with examples taken from Cornwall (Simons et al. 2016, 2017; Manning and Hill 1990), Portugal (Charoy and Noronha 1996; Neiva 2002; Michaud 2019; Michaud and Pichavant 2020), French Massif Central (Raimbault et al. 1995; Raimbault and Burnol 1998; Villaros and Pichavant 2019), Armorican Massif (Ballouard et al. 2015), Spain (Chicharro et al. 2016), Erzgebirge (Breiter et al. 2005) and from the Macusani Volcanics (Pichavant et al. 1987). Variscan granites include peraluminous biotite, biotite-muscovite, muscovite and rare metal granites. They exhibit various degrees of fractionation marked, on major elements, by an increase of $A^{*}$ at decreasing $B^{*}$ (Fig. 10a). For the comparison with melts to be meaningful, granite whole rocks should be representative of their parental liquid compositions. Although this might not be the case for all examples in Fig. 10, peraluminous biotite, biotite-muscovite, muscovite leucogranites and RMGs are generally considered to be emplaced as almost pure liquids (Raimbault et al. 1995; Scaillet et al. 1995; Patiño Douce and Harris 1998; Villaros and Pichavant 2019). All experimental melts from this study plot in the field of peraluminous muscovite-biotite/ muscovite granites (Fig. 10a). Again, no major difference emerges with the nature of the protolith implying that leucogranites with similar major element chemistries can be generated by melting of either an orthogneissic or a paragneissic source rock (see the discussion on major element compositions). The Pg melt compositions do not extend into the high $B^{*}$ domain characteristic of biotite granites (Fig. 10a). This is the consequence of biotite being part of the residual phase assemblage in the $850{ }^{\circ} \mathrm{C} \mathrm{Pg}$ which buffers the concentration of ferromagnesian components in the melt (see above). No partial melt from this study approaches the most strongly peraluminous and leucocratic major element compositions characteristic of RMGs and volcanic equivalents (field with highest $A^{*}$ and lowest $B^{*}$ in Fig. 10a).

In comparison with the reference middle continental crust, most Variscan granites are rare element enriched. The evolution from peraluminous biotite, biotite-muscovite, muscovite leucogranites to RMGs and volcanic equivalents is marked by increasing $\mathrm{Nb}, \mathrm{Ta}$ and $\mathrm{Li}$ at increasing $\mathrm{Rb}$ (Fig. 10b, 11). In some peraluminous granites, $\mathrm{W}$ reaches high concentration levels, in the RMG range (Fig. 11c). Peraluminous granites and RMGs plot below the reference $\mathrm{Nb} / \mathrm{Ta}$ of the middle continental crust, the chemical evolution from the least to the most enriched compositions being marked by a strong decrease of $\mathrm{Nb} /$ Ta with increasing Nb (Fig. 10b, Stepanov et al. 2014). For some elements ( $\mathrm{Li}, \mathrm{Rb}, \mathrm{Ta})$, concentrations in experimental glasses ( $\mathrm{Pg}$ and $\mathrm{Og}$ ) and in the least evolved peraluminous granites overlap. However, the most fractionated rocks are way more enriched than the experimental 
Fig. 10 Comparison between experimental melts from this study (Tables 4, 5) and compositions of Variscan granites and volcanic equivalents (Cornwall: Simons et al. 2016, 2017; Manning and Hill 1990; Portugal: Charoy and Noronha 1996; Neiva 2002; Michaud 2019; Michaud and Pichavant 2020; French Massif Central: Raimbault et al. 1995; Raimbault and Burnol 1998; Villaros and Pichavant, 2019; Armorican Massif: Ballouard et al. 2015; Spain: Chicharro et al. 2016; Erzgebirge: Breiter et al. 2005; Macusani Volcanics: Pichavant et al. 1987). a Major element compositions plotted in the $A^{*}-B^{*}$ diagram of Debon and Lefort (1983), see Tables 1 and 4. b Nb/Ta vs. $\mathrm{Nb}$ content. In both diagrams, the $\mathrm{C}_{\text {melt }}$ data (either for the $\mathrm{Pg}, \mathrm{Pg}_{\text {melt }}$ or for the $\mathrm{Og}, \mathrm{Og}_{\text {melt }}$ ) are plotted using the same color coding as in Fig. 7, the small symbols representing individual analyses and the large symbols median values (Table 5). In (b), the $\mathrm{C}_{\text {mix }}$ individual analyses for the orthogneiss $\left(\mathrm{Og}_{\text {mix }}\right)$ at 800 and $850{ }^{\circ} \mathrm{C}$ (Table 6) and the $C_{\text {per }}$ data for the orthogneiss at $800{ }^{\circ} \mathrm{C}(\mathrm{Og}$ $800{ }^{\circ} \mathrm{C}$ ) are also plotted for comparison (method 1: median from Table A7 and method 2 from Table A9). The large open blue square and black diamond, respectively, labeled $\mathrm{Pg}$ and $\mathrm{Og}$ represent the whole-rock compositions of the two protoliths. Compositions of starting muscovite in the orthogneiss ( $\mathrm{Ms} \mathrm{Og}$ ) and of starting biotite in the orthogneiss $(\mathrm{Bt} \mathrm{Og})$ and paragneiss $(\mathrm{Bt} \mathrm{Pg})$ are shown. The horizontal dashed line gives the mean $\mathrm{Nb} / \mathrm{Ta}$ composition of the middle continental crust (Rudnick and Gao 2003). Fields for protoliths, leucosomes and restites from the Ivrea zone, Italy, all labeled with an asterisk, are indicated for reference (Data from Bea and Montero 1999 see also Stepanov and Hermann 2013)

glasses (Fig. 11). Differences are large and the most enriched experimental glasses have $\mathrm{Li}$ and Ta concentrations about $\sim 1$ order of magnitude lower than RMGs. The $\mathrm{Nb}$ contents of the least enriched $(\mathrm{Pg})$ glasses are similar to peraluminous granites whereas the most enriched $(\mathrm{Og})$ are in the RMG range (Fig. 11a). W is the other element whose experimental concentrations (particularly in $\mathrm{Og}$ ) are comparable to concentrations in RMGs and volcanic equivalents (Fig. 11c). The $\mathrm{Nb} / \mathrm{Ta}$ of $\mathrm{Pg}$ melts plots with the least evolved peraluminous granites, similar to leucosomes in granulite facies metapelites (Bea and Montero, 1999) and slightly below the middle continental crust and restites from biotite dehydration-melting (Fig. 10b). In comparison, the $\mathrm{Nb} / \mathrm{Ta}$ of $\mathrm{Og}$ melts are higher than the range of natural granites and also than restites (Fig. 10b). As for the major elements, the trace element characteristics of the melts are the direct result of melting mechanisms in the experiments. The high $\mathrm{Nb}, \mathrm{W}, \mathrm{Nb} / \mathrm{Ta}$ of $\mathrm{Og}$ melts generated by muscovite dehydration-melting reflect the major role of muscovite in the supply of these elements. The small abundance of peritectic biotite in $\mathrm{Og}$ charges (a consequence of the Og felsic bulk composition) limits biotite/melt $\mathrm{Nb} / \mathrm{Ta}$ fractionation (i.e., preferential sequestration of $\mathrm{Nb}$ than $\mathrm{Ta}$ in biotite, Stepanov and Hermann 2013) and allows the melt $\mathrm{Nb}$ concentration and $\mathrm{Nb} / \mathrm{Ta}$ to remain high, not so different from in the starting muscovite (Figs. 10b, 11). In contrast, the $\mathrm{Nb} / \mathrm{Ta}$ of $\mathrm{Pg}$ melts at $850{ }^{\circ} \mathrm{C}$ is mainly controlled by biotite dehydration-melting, both melt and biotite having similar $\mathrm{Nb} / \mathrm{Ta}$ ratios (Fig. 10b). As biotite persists as a residual phase,
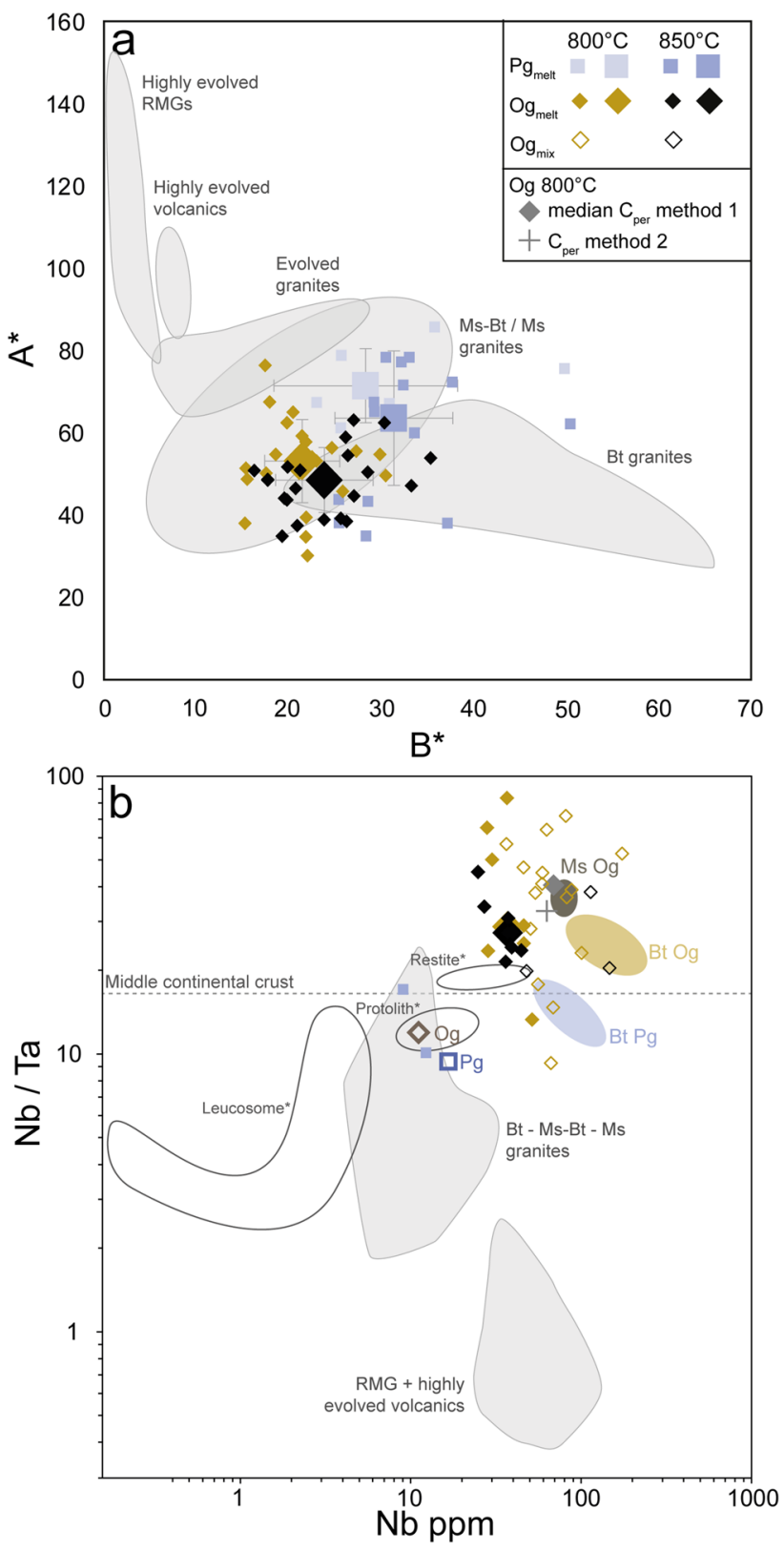

$\mathrm{Nb}$ remains preferentially sequestered in biotite and melts are not $\mathrm{Nb}$-enriched, in good agreement with Stepanov and Hermann (2013). The $\mathrm{Nb}$ depletion in leucosomes when compared to amphibolite grade metasediments ("protolith" in Fig. 10b) is also consistent with biotite being involved either as a peritectic or a residual phase. Similarly, the higher Li concentrations in Pg than in Og melts reflect the respective proportions of reactant biotite in (2) and (3). Overall, and while noting that caution is required with the use of whole-rock data as proxies of melt concentrations (see Michaud and Pichavant 2020 for illustration), significant differences exist between the rare element patterns of experimental melts and Variscan granites. 


\section{Influence of rare element pre-concentration}

Differences between experimental and natural compositions (Figs. 10,11) can be interpreted in various ways, one possible explanation revolving around the nature of the protoliths used in the experiments. On the one hand, our Og protolith is somewhat atypical as it leads to peritectic assemblages relatively poor in $\mathrm{Bt}_{\text {per }}$ which impacts the $\mathrm{Li}, \mathrm{Cs}, \mathrm{Nb}, \mathrm{Ta}$ distributions and $\mathrm{Nb} / \mathrm{Ta}$ fractionation (see above). Nevertheless, the important point is that mechanisms of rare element distribution during muscovite dehydration-melting have been clarified from the $\mathrm{Og}$ and can now be applied to other protoliths such as metapelites. On the other hand, it has been commonly proposed that specific rare element pre-enriched protoliths are required for the production of evolved rare element-enriched granitic melts (Romer and Kroner, 2015; Ballouard et al. 2018; Roda-Robles et al. 2018) and it is worth recalling that the $\mathrm{Og}$ is representative of a such a preconcentrated source. Yet, glasses and glass-peritectic phase mixtures generated from the $\mathrm{Og}$ are not uniformly enriched in rare elements. For W, the high concentrations in experimental melts (medians $\sim 30-40 \mathrm{ppm}$, Table 5) and peritectic mixtures (up to $200 \mathrm{ppm}$, Table 6) match the $\mathrm{W}$ enrichment in the source rock $(\sim 17 \mathrm{ppm}$, Table 1; Fig. 11c) but the high $\mathrm{Nb}$ and $\mathrm{Ta}$ concentrations have no equivalence in the bulk source (Fig. 11a, b) and the Li (Fig. 11d) and Cs melt concentrations are not very high despite their enrichments in the $\mathrm{Og}$. We also point out that melts with the highest $\mathrm{Li}$ (168-198 ppm in the $850{ }^{\circ} \mathrm{C} \mathrm{Pg}$ charge, Table 5; Fig. 11d) derive from the least Li-rich protolith. Thus, source preconcentration is not the only process controlling the trace element contents of anatectic melts.

Mobilization of rare elements depends on proportions of reactants in the melting reaction and on their rare element concentrations. For a given melting reaction and $\mathrm{P}-\mathrm{T}$ conditions (hence fixed reactant proportions), the amount of mobilized rare elements increases with the rare element concentration of reactants. Therefore, a source rock with "enriched" reactant phases will supply a higher amount of rare elements than a barren protolith. However, melting reactions and proportions of reactants are specific of the protolith, sensitively depending on its bulk chemistry and mineralogy as illustrated in Table 7. In addition, mobilization is only one step in the overall process and so a high amount of mobilized rare elements does not necessarily result in their complete transfer to the melt. This is best illustrated by Og experiments which show that, upon muscovite dehydration-melting, $\mathrm{Nb}$ and $\mathrm{Ta}$ are preferentially sequestered in the peritectic assemblage (Fig. 11a, b). In contrast, Li and Cs are strongly partitioned toward the melt. For those elements, melt-peritectic partitioning has a lesser role and source pre-enrichment is potentially more important than for $\mathrm{Nb}$ and $\mathrm{Ta}$. We conclude that rare element pre-concentration has some influence on enrichment levels attainable in the melt. However, this influence is highly selective between rare elements and we caution against source pre-concentration being viewed as the only factor controlling the generation of "enriched" crustal melts. The type of melting reaction, proportions of reactants, their individual rare element concentrations and restite-melt partitioning are equally important.

\section{Implications for rare element-rich melt generation}

Another possible explanation for the geochemical differences between experimental melts and natural granites (Figs. 10,11) concerns melting mechanisms. An anatectic origin is generally considered for the least evolved crustal peraluminous magmas but also, in the frame of the crystallization-differentiation model, for magmas parental to RMGs and LCT pegmatites (e.g., Raimbault et al. 1995; Breaks et al. 2005; Černý et al. 2005; Roda-Robles et al. 2018; Villaros and Pichavant, 2019). Our results confirm that mica dehydration-melting (i.e., reactions (3) and (2)) can produce peraluminous crustal melts similar to Variscan muscovite granites (Fig. 10, Patiño Douce and Harris 1998). However, these melting mechanisms apparently fail to generate the most peraluminous, leucocratic and rare element-enriched compositions. In the following we discuss (1) fluid-present melting and (2) residual source melting.

According to the first model, devolatilization of the lower crust generates carbonic fluids rich in $\mathrm{F}$ and $\mathrm{Cl}$ which are also transporting agents for $\mathrm{Li}, \mathrm{Cs}$ and $\mathrm{Sn}$ and explain their large-scale depletions in granulites (Cuney and Barbey 2014 and references therein). Influx of deep fluids promotes partial melting at intermediate crustal levels leading to the generation of F- and rare metal-rich granitic melts (Cuney and Barbey 2014). Despite some debatable points such as the fluid control of element fractionation in the lower crust (see Stepanov and Hermann 2013 for an alternative interpretation), this fluid-present model accounts for many geological and geochemical features of rare metal magmatism in orogenic belts such as the Variscan. However, unfortunately, experimental information is still almost totally lacking on fluid-present melting, defined here as melting of crustal protoliths in presence of a fluid phase of complex and variable compositions (Montel et al. 1986; Johannes and Holtz 1996; Villaros et al. 2018b). Experimental results from this study contribute very little on this mechanism since the exploratory fluid-present experiments mentioned earlier had high melt fractions inconsistent with degrees of melting for peraluminous granites and the fluid-present reaction (1) is only important near the solidus. To discuss the behavior of major and trace elements during fluid-present melting, the systematic determination of melting reactions, phase assemblages, melt compositions and fluid/melt partition coefficients as a 

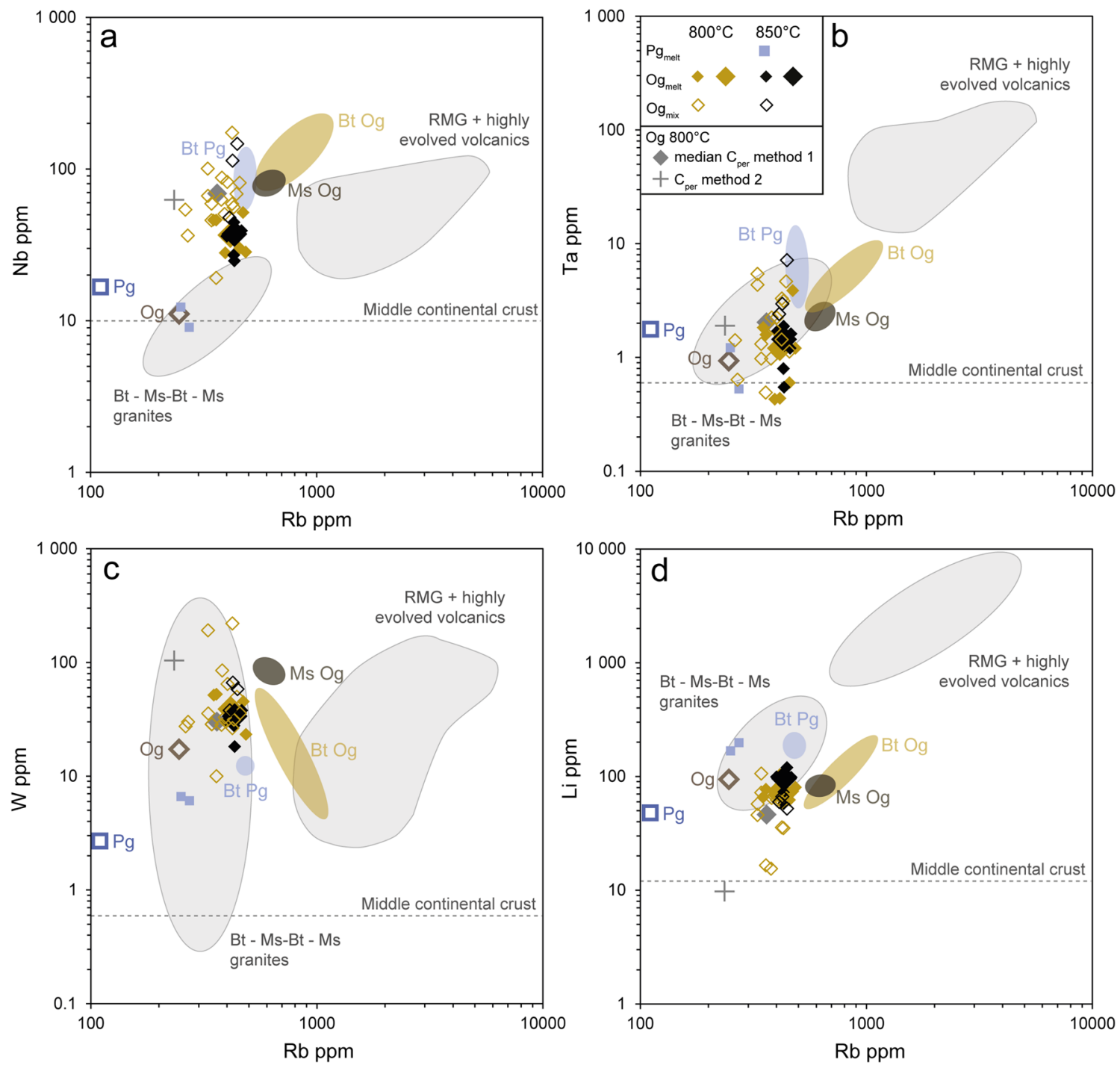

Fig. 11 Comparison between experimental melt from this study (Table 5) and trace element compositions of Variscan granites and volcanic equivalents (same natural examples as in Fig. 10). a $\mathrm{Nb}, \mathbf{b}$ $\mathrm{Ta}, \mathbf{c ~ W}, \mathbf{d ~ L i}$ concentrations plotted as a function of $\mathrm{Rb}$. In all diagrams, the $C_{\text {melt }}$ data (either for the $\mathrm{Pg}, \mathrm{Pg}_{\text {melt }}$ or for the $\mathrm{Og}, \mathrm{Og}_{\text {melt }}$ ) are plotted using the same color coding as in Fig. 6, the small symbols representing individual analyses and the large symbols median values (Table 5). In (b), the $C_{\text {mix }}$ individual analyses for the orthogneiss $\left(\mathrm{Og}_{\text {mix }}\right)$ at 800 and $850{ }^{\circ} \mathrm{C}$ (Table 6) and the $C_{\text {per }}$ data for the

function of pressure, temperature and fluid composition is needed.

In the second model, illustrated below using the Variscan belt as an example, the melting scenario involves two successive melting events (e.g., Wolf et al. 2018). First, conditions of muscovite dehydration-melting are reached in the continental crust and muscovite-bearing lithologies undergo partial melting. P-T paths show a generalized melting event at $330 \mathrm{Ma}$ in the Variscan belt (Faure et al. 2005, Gébelin et al. 2007, Le Carlier de Veslud et al. 2013), under

orthogneiss at $800{ }^{\circ} \mathrm{C}\left(\mathrm{Og} 800{ }^{\circ} \mathrm{C}\right)$ are also plotted for comparison (method 1: median from Table A7 and method 2 from Table A9). The large open blue square and black diamond, respectively, labeled Pg and $\mathrm{Og}$ represent the whole-rock compositions of the two protoliths. Compositions of starting muscovite in the orthogneiss (Ms Og) and of starting biotite in the orthogneiss $(\mathrm{Bt} \mathrm{Og}$ ) and paragneiss $(\mathrm{Bt} \mathrm{Pg}$ ) are shown. The horizontal dashed lines give the mean compositions of the middle continental crust (Rudnick and Gao 2003)

conditions compatible with the generation of biotite-muscovite/muscovite peraluminous granites by muscovite dehydration-melting (FMC: Melleton et al. 2009, Faure et al. 2005, Lardeaux 2014; Cornwall: Simons et al. 2016). Following reaction (3), rare elements are released and distribute between the generated melt and the restitic assemblage. Depending on mechanisms of melt extraction, variable levels of enrichment in ascending magmas are generated for rare elements mobilized during muscovite dehydration-melting such as W. This provides a general explanation for the spatial 
association between biotite-muscovite/muscovite peraluminous granites and hydrothermal $\mathrm{W}$-deposits, both in the Variscan belt (e.g., Cornwall: Simons et al. 2016; FMC: Harlaux et al. 2018) and beyond (e.g., China: Yuan et al. 2019; Rwanda: Hulsbosch 2019). Second, conditions of biotite dehydration-melting are attained in some specific parts of the belt most probably in response to local thermal anomalies (e.g., Velay: Barbey et al. 2015, Villaros et al. 2018a; Cornwall: Simons et al. 2016). Restitic biotite-bearing lithologies (made of residual plus peritectic phases from the first melting event), undergo partial melting. Our results show that the peritectic assemblage left after muscovite dehydration-melting is enriched in $\mathrm{Nb}, \mathrm{Ta}, \mathrm{W}$ compared to the initial protolith, the behavior of Sn being still uncertain (see above, Wolf et al. 2018). Enrichment of Li in the peritectic assemblage, although not observed in this study, would go along with the proportion of peritectic or residual biotite and is to be expected for protoliths derived from mica-rich metapelites. Such a residual, rare element-enriched assemblage makes an appealing source for the generation of RMGlike melts. Biotite dehydration-melting would, thus, result in the production of Li-, Nb-, Ta- and W-rich melts with low $\mathrm{Nb} / \mathrm{Ta}$ although detailed information on melting reactions, phase assemblages and melt compositions are still necessary. In particular, it remains to be demonstrated that the residual source model can lead to chemically specific melts, both for major (strongly peraluminous and leucocratic) and rare elements (strongly enriched in Li, Ta, Fig. 11).

Our experimental results and the evaluation of alternatives to mica dehydration-melting emphasize difficulties with the genesis of RMG-like melts by purely anatectic processes. However, RMGs might be produced by a combination of petrogenetic processes rather than by partial melting alone. For example, crystallization differentiation might act together with mica dehydration-melting to produce the distinctive RMG geochemical signatures (e.g., Pichavant et al. 1988b; Raimbault et al. 1995; Roda-Robles et al. 2018; Michaud and Pichavant 2020). Evaluation of this scenario requires combined melting-fractionation models incorporating the type of information presented in this study for partial melting processes.

\section{Conclusions}

In this study, we have emphasized the role of melting mechanisms and experimentally documented the behavior of representative rare elements upon micas dehydration-melting in the continental crust. Despite the contrasted nature and mineral modal abundances of the two protoliths, and the different melt distributions, melt major element compositions are nearly homogeneous, a result of the combined influence of the main melting reactions. In contrast, the significant variability of melt trace element compositions originates from heterogeneities in the starting materials (i.e., mineral compositions and distribution).

The amounts and the behavior of rare elements released upon melting is controlled by the stoichiometry of the reaction, the nature, proportions and compositions of reactant phases and the partition coefficients between melt, residual and peritectic phases. Rubidium, $\mathrm{Nb}$, Ta and $\mathrm{W}$ are enriched and $\mathrm{Li}$ and $\mathrm{Cs}$ depleted in $\mathrm{Og}_{\text {melts }}$ compared to source rock while $\mathrm{Pg}_{\text {melts }}$ are strongly enriched in $\mathrm{Li}$ and also in $\mathrm{Rb}$, $\mathrm{Cs}$, and $\mathrm{W}$. Upon muscovite dehydration-melting, $\mathrm{Li}$ and Cs strongly and $\mathrm{Rb}$ slightly partition into the melt, whereas $\mathrm{Nb}$, Ta and $\mathrm{W}$ partition to the peritectic assemblage. Upon partial biotite dehydration-melting, limited data indicate a partitioning of $\mathrm{Li}$ and $\mathrm{Cs}$ into the melt in contrast to $\mathrm{Nb}$ and Ta. The modal proportion of biotite, either peritectic or residual, strongly affects the behavior of $\mathrm{Li}, \mathrm{Rb}, \mathrm{Nb}, \mathrm{Ta}$ but not of $\mathrm{W}$, and the $\mathrm{Nb} / \mathrm{Ta}$.

Melt major element compositions are similar to those of muscovite of the Variscan belt of Western Europe but strongly differ from RMGs and volcanic equivalents. In addition, trace element patterns are also contrasted between experimental melts and natural compositions. These mismatches might partly reflect the specificities of the starting materials. Though, the persisting issues with genesis of RMG-like melts through partial melting alone suggest that petrogenetic processes such as crystallization differentiation might be combined to micas dehydration-melting. Besides, fluid-present and multistage melting remain to be tested experimentally as alternatives.

Supplementary Information The online version contains supplementary material available at https://doi.org/10.1007/s00410-021-01855-9.

Acknowledgements This study was initiated as part of the doctoral thesis of JM supported by the Labex VOLTAIRE (ANR-10LABX-100-01), the ERAMIN project NewOres and the ANR project VARPEG (ANR-15-CE01-0001). The authors acknowledge Dr. I. Di Carlo for assistance with analyses at the microprobe. The manuscript significantly benefited from the relevant recommendations and comments of the Editor in Chief Pr. Dr. Othmar Müntener, Pr. Dr. Robert Linnen and an anonymous reviewer.

\section{References}

Acosta-Vigil A, Buick I, Hermann J, Cesare B, Rubatto D, London D, Morgan GB (2010) Mechanisms of crustal anatexis: a geochemical study of partially melted metapelitic enclaves and host dacite, SE Spain. J Petrol 51:785-821

Albarède F (1995) Introduction to geochemical modeling. Cambridge University Press, Cambridge, p 543

Ballouard C, Boulvais P, Poujol M, Gapais D, Yamato P, Tartèse R, Cuney M (2015) Tectonic record, magmatic history and hydrothermal alteration in the Hercynian Guérande leucogranite, Armorican Massif, France. Lithos 220-223:1-22 
Ballouard C, Poujol M, Zeh A (2018) Multiple crust reworking in the French Armorican Variscan belt: implication for the genesis of uranium-fertile leucogranites. Int J Earth Sci 107:2317-2336

Barbey P, Villaros A, Marignac C, Montel J-M (2015) Multiphase melting, magma emplacement and P-T-time path in late-collisional context: the Velay example (Massif Central, France). Bull Soc Géol France 186(2-3):93-116

Bea F, Montero P (1999) Behavior of accessory phases and redistribution of $\mathrm{Zr}$, REE, Y, Th, and $\mathrm{U}$ during metamorphism and partial melting of metapelites in the lower crust: an example from the Kinzigite Formation of Ivrea-Verbano, NW Italy. Geochim Cosmochim Acta 63:1133-1153

Bea F, Pereira MD, Stroh A (1994) Mineral/leucosome trace-element partitioning in a peraluminous migmatite (a laser ablation-ICPMS study). Chem Geol 117:291-312

Belkasmi M, Cuney M, Pollard PJ, Bastoul A (2000) Chemistry of the $\mathrm{Ta}-\mathrm{Nb}-\mathrm{Sn}-\mathrm{W}$ oxide minerals from the Yichun rare metal granite (SE China): genetic implications and comparison with Moroccan and French Hercynian examples. Mineral Mag 64:207-523

Breaks F W, Selway J B, Tindle A C (2005) Fertile peraluminous granites and related rare-element pegmatites, Superior Province of Ontario. In: Linnen RL, Sampson IM (eds) Rare-element geochemistry and mineral deposits. Geol. Soc. Can. Short Course Notes, St. Catharines, 17:87-125

Brearley FW (1987) An experimental and kinetic study of the breakdown of aluminous biotite at $800{ }^{\circ} \mathrm{C}$ : reaction microstructures and mineral chemistry. Bull Miner 110:513-532

Brearley AJ, Rubie DC (1990) Effects of $\mathrm{H}_{2} \mathrm{O}$ on the Disequilibrium breakdown of muscovite+quartz. J Petrol 31(4):925-956

Breiter K, Müller A, Leichmann J, Gabašova A (2005) Textural and chemical evolution of a fractionated granitic system: the Podlesí stock, Czech Republic. Lithos 80:323-345

Brown GC, Fyfe WS (1970) The production of granitic melts during ultrametamorphism. Contrib Mineral Petrol 28:310-318

Burnham CW (1979) Magma and hydrothermal fluids. In: Barnes HL (ed) Geochemistry of hydrothermal ore deposits, 2nd edn. Wiley Interscience, New York, pp 71-136

Cameron EN, Jahns RH, McNair AH, Page LR (1949) Internal structure of granitic pegmatites. Econ Geol Monograph 2:155p

Carignan J, Hild P, Mevelle G, Morel J, Yeghicheyan D (2001) Routine analyses of trace elements in geological samples using flow injection and low pressure on-line liquid chromatography coupled to ICP-MS: a study of geochemical reference materials BR, DR-N, UB-N, AN-G and GH. Geostand News1 25:187-198

Carlier Le, de Veslud C, Alexandre P, Ruffet G, Cuney M, Cheilletz A (2013) A two-stage exhumation in Western French Massif Central: new geochronological evidences of syn-collisional extension. Lithos 175-176:1-15. https://doi.org/10.1016/j.lithos.2013. 04.013

Černý P (1991) Rare-element granitic pegmatites. Part 1: anatomy and internal evolution of pegmatite deposits. Part 2: regional to global environments and petrogenesis. Geosci Canada 18:49-81

Černý P (1992) Geochemical and petrogenetic features of mineralization in rare-element granitic pegmatites in the light of current research. Appl Geochem 7:393-416

Černý P, Ercit TS (2005) The classification of granitic pegmatites revisited. Can Mineral 43:2005-2026

Černý P, Masau M, Goad BE, Ferreira K (2005) The Greer Lake leucogranite, Manitoba, and the origin of lepidolite-subtype granitic pegmatites. Lithos 80:305-321

Cesare B (2000) Incongruent melting of biotite to spinel in a quartzfree restite at El Joyazo (SE Spain): Textures and reaction characterization. Contrib Miner Petrol 139:273-284
Chappell BW, White AJR, Wyborn D (1987) The importance of residual source material (restite) in granite petrogenesis. J Petrol 28:1111-1138

Charoy B, Noronha F (1996) Multistage growth of a rare-element, volatile-rich microgranite at Argemela (Portugal). J Petrol 37:73-94

Chicharro E, Boiron M-C, López-García JÁ, Barfod DN, Villaseca C (2016) Origin, ore forming fluid evolution and timing of the Logrosán Sn-(W) ore deposits (Central Iberian Zone, Spain). Ore Geol Rev 72:896-913

Christiansen EH, Sheridan MF, Burt DM (1986) The geology and geochemistry of Cenozoic topaz rhyolite from the western United Stated. Geol Soc Am Spec Paper 205:1-82

Clemens JD, Stevens G (2016) Melt segregation and magma interactions during crustal melting: breaking out of the matrix. Earth Sci Rev 160:333-349

Clemens JD, Vielzeuf D (1987) Constrains on melting and magma production in the crust. Earth Planet Sci Lett 86:287-306. https:// doi.org/10.1016/0012-821X(87)90227-5

Connolly JAD, Holness MB, Rushmer T, Rubie DC (1997) Reactioninduced micro-cracking: an experimental investigation of a mechanism for enhancing anatectic melt extraction. Geology 25:591-594. https://doi.org/10.1130/0091-7613(1997)025\% 3c0591:RIMAEI\%3e2.3.CO;2

Crevola G (1987) Les orthomicaschistes, produits de la déformation cisaillante ductile synmétamorphe de granites avec transfert de matière: principaux caractères et exemples dans la chaîne Varisque du Sud de la France. Geodin Acta 1:207-221

Cuney M, Barbey P (2014) Uranium, rare metals, and granulite-facies metamorphism. Geosci Front 5:729-745

Cuney M, Marignac C, Weisbrod A (1992) The Beauvoir topazlepidolite albite granite (Massif Central, France); the disseminated magmatic Sn-Li-Ta-Nb-Be mineralization. Econ Geol 87:1766-1794

Debon F, Le Fort P (1983) A chemical-mineralogical classification of common plutonic rocks and associations. Trans Roy Soc Edinburgh 73:135-149

Deveaud S, Gumiaux C, Gloaguen E, Branquet Y (2013) Spatial statistical analysis applied to rare-element LCT-type pegmatite fields: an original approach to constrain faults-pegmatites-granites relationships. J Geosci 58:163-182. https://doi.org/10.3190/jgeosci. 141

Devineau K, Pichavant M, Villiéras F (2005) Melting kinetics of granitic powder aggregates at $1175^{\circ} \mathrm{C}, 1 \mathrm{~atm}$. Eur J Mineral $17: 387-398$

Falster AU, Simmons Wm B, Webber KL (1997) The origin of evolved LCT-type granitic pegmatites in the Hoskin Lake granite-pegmatite field, Florence Co., Wisconsin. IAVCEI General Assembly, Jan. 1997, Puerto Vallarta, Mexico, Programme, pp 118

Faure M, BéMézème E, Duguet M, Cartier C, Talbot J-Y (2005) Paleozoic tectonic evolution of medio-europa from the example of the French massif central and massif armoricain. J Virt Explor Electron Edit 19(5):1-26

Faure M, Lardeaux J-M, Ledru P (2009) A review of the pre-Permian geology of the Variscan French Massif Central. CR Geosci 341:202-213. https://doi.org/10.1016/j.crte.2008.12.001

Gaudel T (2016) Conditions de pic de métamorphisme enregistrés par les gneiss de l'unité de la Dronne (Limousin): les limites de la fusion partielle dans le l'Ouest du Massif Central Français. Master's thesis, University of Orléans, pp 28

Gébelin A, Brunel M, Monié P, Faure M, Arnaud N (2007) Transpressional tectonics and Carboniferous magmatism in the Limousin, Massif Central, France: Structural and 40Ar/39Ar investigations. Tectonics 26:1-27. https://doi.org/10.1029/2005TC001822

Goodenough KM, Lusty PAJ, Roberts NMW, Key RM, Garba A (2014) Post-collisional Pan-African granitoids and rare metal pegmatites in western Nigeria: age, petrogenesis, and the "pegmatite 
conundrum.” Lithos 200-201:22-34. https://doi.org/10.1016/j. lithos.2014.04.006

Haapala I, Lukkari S (2005) Petrological and geochemical evolution of the Kymi stock, a topaz granite cupola within the Wiborg rapakivi batholith, Finland. Lithos 80:347-362

Hammouda T, Pichavant M (1999) Kinetics of melting of fluorphlogopite-quartz pairs at 1 atmosphere. Eur J Mineral 11:637-653

Hammouda T, Pichavant M (2000) Melting of fluorphlogopiteplagioclase pairs at 1 atmosphere. Eur J Mineral 12:315-328

Hanson GN (1978) The application of trace elements to the petrogenesis of igneous rocks of granitic composition. Earth Planet Sci Lett 38:26-43

Harlaux M, Mercadier J, Marignac C, Peiffert C, Cloquet C, Cuney M (2018) Tracing metal sources in peribatholitic hydrothermal W deposits based on the chemical composition of wolframite: the example of the Variscan French Massif Central. Chem Geol 479:58-85. https://doi.org/10.1016/j.chemgeo.2017.12.029

Harris NBW, Inger S (1992) Trace element modelling of pelitederived granites. Contrib Mineral Petrol 110:46-56

Harris NBW, Ayres M, Massey J (1995) Geochemistry of granitic melts produced during the incongruent melting of muscovite: implications for the extraction of Himalayan leucogranite magmas. J Geophys Res 100(B8):14767-15777

Hertogen J, Gijbels R (1976) Calculation of trace element fractionation during partial melting. Geochim Cosmochim Acta 40:313-322

Holyoke CW, Rushmer T (2002) An experimental study of grain scale melt segregation mechanisms in two common crustal rock types. J Metamorph Geol 20:493-512

Huang WL, Wyllie PJ (1974) Melting relations of muscovite with quartz and sanidine in the $\mathrm{K}_{2} \mathrm{O}-\mathrm{Al}_{2} \mathrm{O}_{3}-\mathrm{SiO}_{2}-\mathrm{H}_{2} \mathrm{O}$ system to 30 kilobars and an outline of paragonite melting relations. Am $\mathrm{J}$ Sci 274:378-395

Hulsbosch N, Hertogen J, Dewaele S, Andre L, Muchez P (2014) Alkali metal and rare earth element evolution of rock-forming minerals from the Gatumba area pegmatites (Rwanda): quantitative assessment of crystal-melt fractionation in the regional zonation of pegmatite groups. Geochim Cosmochim Acta 132:349-374

Hulsbosch N (2019) Nb-Ta-Sn-W Distribution in Granite-related Ore Systems: fractionation mechanisms and examples from the Karagwe-Ankole belt of Central Africa. In Ore Deposits American Geophysical Union (AGU), pp 75-107

Icenhower J, London D (1995) An experimental study of element partitioning among biotite, muscovite, and coexisting peraluminous silicic melt at $200 \mathrm{MPa}\left(\mathrm{H}_{2} \mathrm{O}\right)$. Am Miner 80:1229-1251

Icenhower J, London D (1996) Experimental partitioning of Rb, Cs, $\mathrm{Sr}$, and $\mathrm{Ba}$ between alkali feldspar and peraluminous melt. Am Miner 81:719-734

Jahns RH, Burnham CW (1969) Experimental studies of pegmatite genesis; 1, A model for the derivation and crystallization of granitic pegmatites. Econ Geol 64:843-864

Johannes W, Holtz F (1996) Petrogenesis and experimental petrology of granitic rocks. In: Wyllie PJ, El Goresy A, von Engelhardt W, Hahn T (eds) Minerals and rocks 22. Springer-Verlag, Berlin, p 335

Kesraoui M, Marignac C, Verkaeren J (2000) L'évolution tardi-magmatique des granites à métaux rares: l'exemple de la coupole de Tin-Amzi (Hoggar-Algérie). Bulletin De La Société Géologique De L'algérie 11(2):195-216

Kinnaird J, Bowden P, Ixer RA, Odling NWA (1985) Mineralogy, geochemistry and mineralization of the Ririwai complex, northern Nigeria. J Afr Earth Sc 3:185-222

Kontak DJ (1990) The East Kemptville topaz-muscovite leucogranite, Nova Scotia; I. Geological setting and whole-rock geochemistry. Can Mineral 28(4):787-825
Konzett J, Hauzenberger C, Ludwig T, Stalder R (2018) Anatectic granitic pegmatites from the eastern Alps: a case study of variable rare metal enrichment during high-grade regional metamorphism. II. Pegmatite staurolite as an indicator of anatectic pegmatite parent melt formation-a field and experiment study. Can Mineral 56:603-624

Kovalenko VI, Tsaryeva GM, Goreglyad AV, Yarmolyuk VV, Troitsky VA, Hervig RL, Farmer GL (1995) The peralkaline graniterelated Khaldzan-Buregtey rare metal ( $\mathrm{Zr}, \mathrm{Nb}, \mathrm{REE})$ deposit, western Mongolia. Econ Geol 90:530-547

Kovalenko V I, Kovalenko N I (1976) Ongonites (topaz bearing quartz keratophyre) - subvolcanic analogues of rare metal Li-F granites: Nauka, Moskva, pp 124 (in Russian)

Lardeaux J-M (2014) Deciphering orogeny: a metamorphic perspective. Examples from European Alpine and Variscan belts. Part II: Variscan metamorphism in the French Massif Central-a review. Bull Soc Géol France 185(5):281-310

Le Breton N, Thompson AB (1988) Fluid-absent (dehydration) melting of biotite in metapelites in the early stage of crustal anatexis. Contrib Miner Petrol 99:226-237

Le Fort P, Cuney M, Deniel C, France-Lanord C, Sheppard SMF, Upreti BN, Vidal P (1987) Crustal generation of the Himalayan leucogranites. Tectonophysics 134:39-57

Linnen RL, Pichavant M, Holtz F, Burgess S (1995) The effect of fo2 on the solubility, diffusion, and speciation of tin in haplogranitic melt at $850{ }^{\circ} \mathrm{C}$ and 2 kbar. Geochim Cosmochim Acta 59:1579-1588

Linnen R L, Cuney M (2005) Granite-related rare-element deposits and experimental constraints on Ta-Nb-W-Sn-Zr-Hf mineralization. In: Linnen RL and Samson IM (eds) Rare-element geochemistry and mineral deposits. In: Geological Association of Canada, GAC, Short Course Canada

London D (2005) Granitic pegmatites: an assessment of current concepts and directions for the future. Lithos 80:281-303. https:// doi.org/10.1016/j.lithos.2004.02.009

London D (2008) Pegmatites. Canadian Mineralogist Special Publication, 10, pp 368

Lotout C, Pitra P, Poujol M, Van Den Driessche J (2017) Ordovician magmatism in the Lévézou massif (French Massif Central): tectonic and geodynamic implications. Int J Earth Sci 106:501-515

Luth WC (1969) The system $\mathrm{NaAlSi}_{3} \mathrm{O}_{8}-\mathrm{SiO}_{2}$ and $\mathrm{KAlSi}_{3} \mathrm{O}_{8}$ to $20 \mathrm{~kb}$ and the relationship between $\mathrm{H}_{2} \mathrm{O}$ content $\mathrm{pH}_{2} \mathrm{O}$ and $\mathrm{p}_{\text {total }}$ in granitic magmas. Am J Sci 267A:325-341

Manning DAC, Hill PI (1990) The petrogenetic and metallogenetic significance of topaz granite from the Southwest England orefield. Geol Soc Am Spec Pap 246:51-69

Mayne MJ, Moyen J-F, Stevens G, Kaisleniemi L (2016) Rcrust: a tool for calculating path-dependent open system processes and application to melt loss. J Metamorph Geol 34:663-682

Melleton J, Faure M, Cocherie A (2009) Monazite U-Th/Pb chemical dating of the Early Carboniferous syn-kinematic MP/MT metamorphism in the Variscan French Massif Central. Bull Soc Géol France 180(3):283-292

Melleton J, Gloaguen E, Frei D (2015) Rare elements (Li-Be-Ta-Sn$\mathrm{Nb}$ ) magmatism in the European Variscan belt, a review. SGA, Ressources minérales dans un monde durable, Nancy, France pp 807-810

Michaud JA-S, Pichavant M (2020) Magmatic fractionation and the magmatic-hydrothermal transition in rare metal granites: evidence from Argemela (Central Portugal). Geochim Cosmochim Acta 289:130-157. https://doi.org/10.1016/j.gca.2020.08.022

Michaud JA-S (2019) Rare metal granites: origin, emplacement and mechanisms of the magmatic-hydrothermal transition. Insights from the Argemela rare metal granite (Portugal) and an experimental study. PhD thesis, University of Orléans, pp 365 
Misra S, Burlini L, Burg J-P (2009) Strain localization and melt segregation in deforming metapelites. Phys Earth Planet Inter 177:173-179. https://doi.org/10.1016/j.pepi.2009.08.011

Montel J-M, Vielzeuf D (1994) Partial melting of metagreywackes 1. Fluid absent experiments and phase relationships. Contrib Miner Petrol 117:375-393

Montel J-M, Vielzeuf D (1997) Partial melting of metagreywacke-2: compositions of minerals and melts. Contrib Miner Petrol 128:176-196

Montel J-M, Weber C, Barbey P, Pichavant M (1986) Thermo-barométrie du domaine anatectique du Velay (Massif Central, France) et conditions de genèse des granites tardi-migmatitiques. Comptes Rendus Académie Des Sciences Paris 302:647-652

Muller A, Romer R, Pedersen R-B (2017) The Sveconorwegian pegmatite province - thousands of pegmatites without parental granites. Can Mineral 55:283-315

Nabelek PI (1999) Trace element distribution among rock-forming minerals in Black Hills migmatites, South Dakota: a case for solid-state equilibrium. Am Miner 84:1256-1269

Nabelek PI, Russ-Nabelek C, Denison JR (1992a) The generation and crystallization conditions of the Proterozoic Harney Peak Leucogranite, Black Hills, South Dakota, USA: Petrologic and geochemical constraints. Contrib Mineral Petrol 110:173-191

Nabelek PI, Russ-Nabelek C, Haeussler GT (1992b) Stable isotope evidence for the petrogenesis and fluid evolution in the Proterozoic Harney Peak leucogranite, Black Hills, South Dakota. Geochim Cosmochim Acta 56:403-417

Neiva ANAMR (2002) Portuguese granites associated with Sn-W and Au mineralizations. Bull Geol Soc Finl 79(1-2):79-101

PatiñoDouce AE, Harris N (1998) Experimental constraints on Himalayan anatexis. J Petrol 39(4):689-710

Pearce NJG, Perkins WT, Westgate JA, Gorton MP, Jackson SE, Neal CR, Chenery SP (1997) A compilation of new and published major and trace element data for NIST SRM 610 and NIST SRM 612 glass reference materials. Geostand Newsl 21(1):115-144

Pichavant M, Valencia Herrera J, Boulmier S, Briqueu L, Joron JL, Juteau M, Marin L, Michard A, Sheppard SMF, Treuil M, Vernet M (1987) The Macusani glasses, SE Peru: evidence of chemical fractionation in peraluminous magmas. In Magmatic processes: physicochemical principles (ed. B.O. Mysen). Geochem Soc Spec Public 1:359-373

Pichavant M, Kontak DJ, Herrera V, Clark AH (1988a) The MiocenePliocene Macusani Volcanics, SE Peru. I. Mineralogy and magmatic evolution of a two-mica aluminosilicate-bearing ignimbrite suite. Contrib Miner Petrol 100:300-324

Pichavant M, Kontak D, Briqueu L, Valencia Herrera J, Clark AH (1988b) The Macusani Volcanics, SE Peru: II. Geochemistry and origin of a felsic peraluminous magma. Contrib Miner Petrol 100:325-338

Pichavant M, Villaros A, Deveaud S, Scaillet B, Lahlafi M (2016) The influence of redox state on mica crystallization in leucogranite and pegmatitic liquids. Can Mineral 54:559-581

Pillet D, Chevenoy M, Bélanger M (1992) Pétrologie du granite peralcalin du lac Brisson, Labrador central, Nouveau-Québec. 1. Mode de mise en place et évolution chimique. Revue Canadienne Des Sciences De La Terre 29:353-372

Raimbault L (1987) Genèse des granites à métaux rares : Revue comparative des modèles géochimiques. Géol Fr 3:101-108

Raimbault L, Burnol L (1998) The Richemont rhyolite dyke, Massif Central, France; a subvolcanic equivalent of rare-metal granites. Can Mineral 36:265-282

Raimbault L, Cuney M, Azencott C, Duthou J-L, Joron J (1995) Geochemical evidence for a multistage magmatic genesis of Ta-Sn-Li mineralization in the granite at Beauvoir, French Massif Central. Econ Geol 90:548-576
Renno A (1997) Zur Petrogenese der Albitgranite von Abu Dabbab und Nuweibi, Central Eastern Desert, Ägypten. Unpublished PhD Thesis, Technische Universität Berlin, Berlin, pp 216

Robie RA, Hemingway BS, Fisher JR (1979) Thermodynamic properties of minerals and related substances at $298.15 \mathrm{~K}$ and $1 \mathrm{Bar}$ ( $10^{5}$ Pascals) pressure and at higher temperatures. US Geological Survey Bulletin 1452

Roda E, Pesquera A, Velasco F, Fontan F (1999) The granitic pegmatites of the Fregeneda area (Salamanca, Spain): characteristics and petrogenesis. Mineral Mag 63:535-556

Roda-Robles E, Villaseca C, Pesquera A, Gil-Crespo PP, Vieira R, Lima A, Garate-Olave I (2018) Petrogenetic relationships between Variscan granitoids and Li-(F-P)-rich aplite-pegmatites in the Central Iberian Zone: geological and geochemical constraints and implications for other regions from the European Variscides. Ore Geol Rev 95:408-430

Romer R, Kroner U (2015) Sediment and weathering control on the distribution of Paleozoic magmatic tin-tungsten mineralization. Miner Deposita 50:327-338

Rudnick RL, Gao S (2003) Composition of the continental crust. In: Rudnick RL (ed) The crust. Elsevier, Amsterdam, pp 1-70

Rushmer T (2001) Volume change during partial melting reactions: implications for melt extraction, melt geochemistry and crustal rheology. Tectonophysics 342:389-405

Scaillet B, Pichavant M, Roux J (1995) Experimental crystallization of leucogranite magmas. J Petrol 36:663-705

Schmitt AK, Emmermann R, Trumbull RB, Bühn B (2000) Petrogenetic aspects of metaluminous and per-alkaline granites in the Brandberg anorogenic complex, Namibia: evidence for major mantle contribution. J Petrol 41:1207-1239

Schneider CA, Rasband WS, Eliceiri KW (2012) NIH image to ImageJ: 25 years of image analysis. Nat Methods 9:671-675

Shaw DM (1970) Trace element fractionation during anatexis. Geochim Cosmochim Acta 34:237-243

Shaw RA, Goodenough KM, Roberts NMW, Horstwood MSA, Chenery SR, Gunn AG (2016) Petrognenesis of rare-metal pegmatites in high-grade metamorphic terranes: a. Precambr Res 281:338362. https://doi.org/10.1016/j.precamres.2016.06.008

Shearer CK, Papike JJ, Laul JC (1987) Mineralogical and chemical evolution of a rare-element granite-pegmatite system: Harney Peak granite, Black Hills, south Dakota. Geochim Cosmochim Acta 51:473-486

Shearer CK, Papike JJ, Jolliff BL (1992) Petrogenetic links among granites and pegmatites in the Harney Peak rare-element granite-pegmatite system, Black Hills, south Dakota. Can Mineral 30:785-809

Simons B, Shail RK, Andersen JCØ (2016) The petrogenesis of the Early Permian Variscan granites of the Cornubian Batholith: lower plate post-collisional peraluminous magmatism in the Rhenohercynian Zone of SW England. Lithos 260:76-94. https://doi. org/10.1016/j.lithos.2016.05.010

Simons B, Andersen JCØ, Shail RK, Jenner FE (2017) Fractionation of $\mathrm{Li}, \mathrm{Be}, \mathrm{Ga}, \mathrm{Nb}, \mathrm{Ta}, \mathrm{In}, \mathrm{Sn}, \mathrm{Sb}, \mathrm{W}$ and $\mathrm{Bi}$ in the peraluminous Early Permian Variscan granites of the Cornubian Batholith: precursor processes to magmatic-hydrothermal mineralisation. Lithos 278-281:491-512. https://doi.org/10.1016/j.lithos.2017. 02.007

Spear FS (1995) Metamorphic phase equilibria and pressure-temperature-time paths, 2nd edn. Mineralogical Society of America, Washington

Stepanov AS, Hermann J (2013) Fractionation of Nb and Ta by biotite and phengite: implications for the "missing Nb paradox." Geology 41:303-306

Stepanov A, Mavrogenes JA, Meffre S, Davidson P (2014) The key role of mica during igneous concentration of tantalum. Contrib Mineral Petrol 167:1009. https://doi.org/10.1007/s00410-014-1009-3 
Stevens G, Villaros A, Moyen J-F (2007) Selective peritectic garnet entrainment as the origin of geochemical diversity in S-type granites. Geology 35:9-12. https://doi.org/10.1130/G22959A.1

Stewart DB (1978) Petrogenesis of lithium-rich pegmatites. Am Miner 63:970-980

Taylor JR, Wall VJ, Pownceby MI (1992) The calibration and application of accurate redox sensors. Am Miner 77:284-295

Thompson AB (1982) Dehydration Melting of Pelitic rocks and the generation of $\mathrm{H}_{2} \mathrm{O}$-undersaturated granitic liquids. Am J Sci 282:1567-1595

Tumarkina E, Misra S, Burlini L, Connolly JAD (2011) An experimental study of the role of shear deformation on partial melting of a synthetic metapelite. Tectonophysics 503:92-99

Turpin L, Leroy JL, Sheppard SMF (1990) Isotopic (O, H, C, Sr, Nd) of superimposed barren and U-bearing hydrothermal systems in a Hercynian granite, Massif Central, France. Chem Geol 88:85-98

Vielzeuf D, Clemens JD (1992) The fluid-absent melting of phlogopite + quartz: experiments and models. Am Miner 77:1206-1222

Vielzeuf D, Holloway JR (1988) Experimental determination of the fluid-absent melting relations in the pelitic system: consequences for crustal differentiation. Contrib Mineral Petrol 98:257-276

Vielzeuf D, Montel J-M (1994) Partial melting of metagreywackes. Part I. Fluid-absent experiments and phase relationships. Contrib Mineral Petrol 177:375-393

Vielzeuf D, Schmidt MW (2001) Melting relations in hydrous systems revisited: application to metapelites, metagreywackes and metabasalts. Contrib Mineral Petrol 141:251-267

Villaros A, Pichavant M (2019) Mica-liquid trace elements partitioning and the granite-pegmatite connection: the St-Sylvestre complex (Western French Massif Central). Chem Geol 528:119265

Villaros A, Laurent O, Couzinié S, Moyen J-F, Mintrone M (2018a) Plutons and domes: the consequences of anatectic magma extraction-example from the southeastern French Massif Central. Int J Earth Sci 107:2819-2842. https://doi.org/10.1007/ s00531-018-1630-x
Villaros A, Pichavant M, Michaud J (2018b) Experimental melting of ortho- and paragneiss under fluid-present conditions: melt compositions (major and trace elements) and implications for granite genesis. EMPG, Clermont-Ferrand, p 130

Wolf M, Romer RL, Franz L, López-Moro FJ (2018) Tin in granitic melts: the role of melting temperature and protolith composition. Lithos 310-311:20-30

Wolf M (2018) The role of partial melting on trace element and isotope systematics of granitic melts. Potsdam, PhD p 139

Yakymchuk C, Brown M (2014) Behaviour of zircon and monazite during crustal melting. J Geol Soc Lond 171:465-479

Yang P, Rivers T (2000) Trace element partitioning between coexisting biotite and muscovite from metamorphic rocks, Western Labrador: structural, compositional and thermal controls. Geochim Cosmochim Acta 64:1451-1472

Yardley BWD (2009) The role of water in the evolution of the continental crust. J Geol Soc Lond 166:585-600. https://doi.org/10. 1144/0016-76492008-101

Yuan S, Williams-Jones AE, Romer RL, Zhao P, Mao J (2019) Protolith-related thermal controls on the decoupling of Sn and W in Sn-W metallogenic provinces: insights from the Nanling region, China. Econ Geol 114(5):1005-1012

Zhang Y, Ni H, Chen Y (2010) Diffusion data in silicate melts. Rev Mineral Geochem 72:311-408

Zhu J-C, Li R-K, Li F-C, Xiong X-L, Zhou F-Y, Huang X-L (2001) Topaz-albite granites and rare-metal mineralization in the Limu District, Guangxi Province, southeast China. Miner Deposita 36(5):393-405

Publisher's Note Springer Nature remains neutral with regard to jurisdictional claims in published maps and institutional affiliations. 